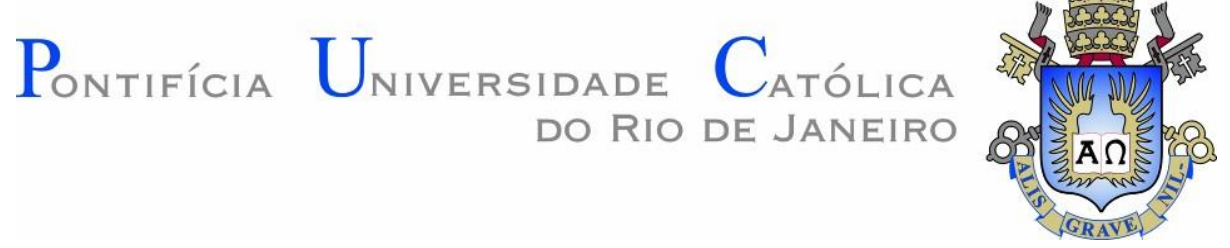

Tatiane Rodrigues Souza

\title{
CONCEPÇÕES DE ALFABETIZAÇÃO: \\ $O$ que dizem professores da rede municipal de ensino de Duque de Caxias/RJ
}

Dissertação de Mestrado

Dissertação apresentada ao Programa de Pós-Graduação em Educação da PUC-Rio como requisito parcial para obtenção do grau de Mestre em Educação.

Orientadora: Prof. ${ }^{a}$ Naira da Costa Muylaert Lima Coorientadora: Prof. ${ }^{a}$ Alícia Maria Catalano de

Bonamino

Rio de Janeiro, Fevereiro de 2021 


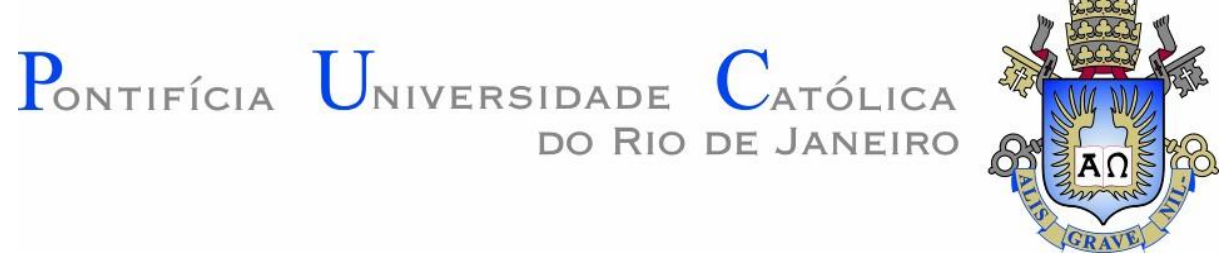

Tatiane Rodrigues Souza

\begin{abstract}
"Concepções de alfabetização: o que dizem professores da rede municipal de ensino de Duque de Caxias/RJ?"
\end{abstract}

Dissertação apresentada como requisito parcial para obtenção do grau de Mestre pelo Programa de Pós-graduação em Educação do Departamento de Educação do Centro de Teologia e Ciências Humanas da PUC-Rio. Aprovada pela Comissão Examinadora abaixo assinada.

\author{
Prof ${ }^{a}$. Naira da Costa Muylaert Lima \\ Orientadora \\ Departamento de Educação - PUC-Rio \\ Profa - Alicia Maria Catalano de Bonamino \\ Co-orientadora \\ Departamento de Educação - PUC-Rio
}

Profa. Maria Cristina Monteiro Pereira de Carvalho Departamento de Educação - PUC-Rio

Prof ${ }^{a}$. Hilda Aparecida Linhares da Silva Micarello

UFJF

Profa. Monah Winograd

Coordenadora Setorial do Centro

de Teologia e Ciências Humanas

PUC-Rio

Rio de Janeiro, 19 de Fevereiro de 2021 
Todos os direitos reservados. A reprodução, total ou parcial, do trabalho é proibida sem autorização do autor, do orientador e da universidade.

Tatiane Rodrigues Souza

Graduou-se em Pedagogia pela Pontifícia Universidade Católica do Rio de Janeiro em 2010. Especialização em Lato Sensu: Dificuldades de Aprendizagem: Prevenção e Reeducação pela UERJ. Atua na área de Educação, com interesse nas áreas de: Alfabetização, Currículo, Implementação de Políticas Públicas e Avaliação.

Ficha Catalográfica

Souza, Tatiane Rodrigues

Concepções de alfabetização : o que dizem professores da rede municipal de ensino de Duque de Caxias/RJ / Tatiane Rodrigues Souza ; orientadora: Naira da Costa Muylaert Lima ; coorientadora: Alícia Maria Catalano de Bonamino. - 2021.

98 f. : il. color. ; $30 \mathrm{~cm}$

Dissertação (mestrado)-Pontifícia Universidade Católica do Rio de Janeiro, Departamento de Educação, 2021.

Inclui bibliografia 


\section{Agradecimentos}

Com alegria, agradeço!

A Deus, por ser meu refúgio e fortaleza em todos os momentos da minha vida, desde o processo de seleção para o mestrado, tornando esse sonho uma realidade, fazendo-me acreditar que era possível e mostrando-me que a trajetória, muitas vezes, é longa e difícil, mas viável quando há perserverança e dedicação.

À minha amada mãe, por ser uma mulher de fé, me incentivando a sonhar mesmo quando tudo parecia impossível. Nos momentos de tristeza, orava por mim dando-me força e impulsionando-me a continuar a jornada.

Ao meu esposo, Michel, por ter sonhando e trilhado comigo a caminhada, sendo companheiro, paciente e amoroso nos meus momentos ausentes, e por ter comemorado muito comigo a cada conquista.

Agradeço às amigas de infância presentes até hoje em minha vida: Fernanda, Helena, Lívia, Maitê, Maísa e Tenille. Obrigada, meninas, pelo incentivo e pelo carinho!

É com muita alegria que agradeço à minha querida orientadora, Naira Muylaert, que, com toda ternura, generosidade, compromisso e dedicação não mediu esforços, palavras e alegria em estar ao meu lado nesse sonho tão especial, acreditando no sonho de uma professora da educação básica e contribuindo para minha formação. Sou grata pelos seus ensinamentos e afeto.

Agradeço à minha coorientadora, Alícia Bonamino, por me incentivar a estudar e pesquisar, desde a graduação como bolsista de iniciação cientifica no estudo do "GERES" (Estudo longitudinal da geração escolar 2005)". Alícia, você marcou minha vida mostrando o quanto é importante dialogar com a teoria e o "chão da escola".

Às professoras Cristina Carvalho, Hilda Micarello, Lúcia Oliveira e Alexandra Pena, por aceitarem o convite de compor a banca examinadora. É um prazer tê-las no meu processo de formação.

Ao grupo de pesquisa LAED agradeço a participação de todos que contribuíram com muitas sugestões para elaboração do meu roteiro de entrevista. Agradeço, especialmente, à Alda e à Deise, pela amizade, carinho e cumplicidade nessa trajetória. Formamos um belo trio nos artigos!

Ao Zé, meu irmão e amigo que, em vários momentos, ajudou para o entendimento das teorias de políticas públicas e com uso das plataformas digitais.

Gratidão à turma de mestrado em Educação 2019, especialmente às amigas Grazielle, Francielen e Mariana que, ao longo desses dois anos, seguiram comigo dando sorrisos e iluminando meus dias mais cinzentos, tornando a caminhada mais feliz e leve. 
Agradeço aos meus familiares Ana Lea, Dandara, Ozinete, Ozielly, Ozianny e Moisés por todo apoio e carinho ao longo da caminhada. Agradeço a minha madrinha Helena por todo carinho e cuidado nessa fase tão especial da minha vida.

Agradeço às minhas amigas professoras da educação básica que me incentivaram a acreditar no sonho: Alexandra, Eveliny, Gabriela, Heliane, Jaqueline, Letícia, Ligia e Simone e Tatiana.

Gratidão à minha orientadora pedagógica Izaura, por despertar o desejo e acreditar no meu sonho, incentivando-me a estudar e a participar da seleção de mestrado. Ao meu orientador educacional Leone, por ter disponibilizado os documentos da rede. Às professoras da escola Maria Anger: Andréa, Andressa, Ana Lúcia, Fabiana, Renata e Rosangela, por serem o meu socorro. Quantas vezes precisei sair mais cedo para conseguir chegar pontualmente nos horários das aulas e vocês se prontificaram a ficar com a minha turma!

As minhas gestoras Rosilana e Vanise, por encorajarem a caminhada e concederem espaço para eu dividir com meus colegas o desenvolvimento da pesquisa.

Gratidão aos educadores e educadoras das escolas da rede municipal de ensino de Duque de Caxias, que são colegas militantes lutando diariamente contra as políticas governamentais de desvalorização do magistério, acreditando em oferecer uma educação emancipatória, resistindo e se reinventando como professores. Agradeço aos docentes que aceitaram o convite para participar das entrevistas, mesmo online. Sem as narrativas de vocês, eu não conseguiria finalizar a dissertação. Quanta aprendizagem!

À Secretaria Municipal de Educação de Duque de Caxias-RJ, por conceder a autorização de pesquisa.

Gratidão ao departamento de educação da PUC -RIO, por fazer parte da minha vida e da minha formação desde a graduação. Após dez anos afastada da vida acadêmica, retornar ao programa da Pós-graduação é emocionante, pois é rememorar as lembranças do passado com as experiências do presente. Agradeço aos professores pela generosidade e pela paciência em compartilhar o conhecimento, tornando a aprendizagem prazerosa. Aos funcionários empenhados a nos informar sobre as exigências do programa, com toda dedicação, mesmo com um ano atípico como 2020.

Agradeço a CAPES pelo incentivo financeiro e auxílios. O presente trabalho foi realizado com apoio da Coordenação de Aperfeiçoamento de Pessoal de Nível Superior - Brasil (CAPES) - Código de Financiamento 001.

Gratidão a todos que me incentivaram a acreditar no meu sonho e que acompanharam, de perto ou distante, essa trajetória. Como diz Clarice Lispector, "quem caminha sozinho pode até chegar mais rápido, mas aquele que vai acompanhado, com certeza chegará mais longe".

Por fim, mas não menos importante, agradeço a todas as crianças que já passaram pela minha vida! 


\section{Resumo}

Souza, Tatiane Rodrigues; Muylaert, Naira da Costa; Bonamino, Alícia Maria Catalano. Concepções de Alfabetização: O que dizem professores da rede municipal de ensino de Duque de Caxias/ RJ. Rio de Janeiro, 2021.Dissertação de Mestrado - Departamento de Educação, Pontifícia Universidade Católica do Rio de Janeiro.

A presente dissertação tem como objetivo compreender as concepções de alfabetização dos professores alfabetizadores da rede municipal de educação de Duque de Caxias, no estado do Rio de Janeiro, relacionando-as ao que consta nos documentos curriculares: aquele formulado em 2002 e que ainda está em vigência; o que está em construção e a Base Nacional Comum Curricular (BNCC). Dentre os objetivos específicos, o estudo buscou compreender os motivos que levaram a SME/Duque de Caxias a reestruturar o currículo da rede de ensino e quais eram as concepções de alfabetização dos profissionais entrevistados e dos documentos curriculares. Para atingir esses objetivos, o estudo fez uso de uma abordagem metodológica qualitativa por meio de duas técnicas de coleta de dados: a análise dos documentos curriculares e das entrevistas. As entrevistas foram realizadas a partir de roteiros semiestruturados com alguns professores alfabetizadores e coordenadores pedagógicos da rede de ensino. Apesar das dificuldades provocadas pela pandemia no novo coronavírus, de um modo geral, pôde-se ter melhor compreensão das concepções de alfabetização dos profissionais da rede municipal de educação de Duque de Caxias/RJ. Além disso, o estudo também conseguiu identificar bases teóricas de alfabetização apresentadas nos documentos curriculares e as concepções presentes de alfabetização na BNCC.

Palavras-Chave: Concepções de alfabetização; Reformulação Curricular; Base Nacional Comum Curricular. 


\section{Abstract}

Souza, Tatiane Rodrigues; Muylaert, Naira da Costa; Bonamino, Alícia Maria Catalano. Conceptions of Literacy: What the teachers in the public school system of Duque de Caxias/ RJ say. Rio de Janeiro, 202. Dissertação de Mestrado - Departamento de Educação, Pontifícia Universidade Católica do Rio de Janeiro.

The objective of this dissertation is to understand the conceptions of literacy held by literacy teachers from the public school system of Duque de Caxias, in the state of Rio de Janeiro, in conjunction with what is in the curriculum policy documents: the one formulated in 2002 and that is still effective until this day; the one under construction and the National Common Core Curriculum (BNCC). Among the specific objectives, the study aimed at perceiving the reasons that led the Municipal Department of Education of Duque de Caxias to restructure the curriculum of the school system, what the conceptions of literacy held by the teachers of the public school system and by the curriculum policy documents are. In order to achieve these objectives, the study used a qualitative methodological approach through two data collection techniques: the analysis of the curriculum documents and of the interviews. The interviews were conducted with the use of semi-structured scripts with literacy teachers and pedagogical coordinators of the public school system. Besides the difficulties caused by the new coronavirus pandemic, the study was successful in getting a better understanding of the conceptions of literacy held by professionals from the public school system of Duque de Caxias. Moreover, the study also managed to identify the main theoretical bases of literacy presented in the curriculum documents and in the National Common Core Curriculum (BNCC).

Keywords: Conceptions of Literacy; Curriculum Reform; National Common Core Curriculum. 


\section{Sumário}

1. Introdução 10

2. Concepções de alfabetização na educação brasileira 15

3. Concepções de alfabetização presentes na BNCC 31

4.A atual reestruturação curricular do município de Duque de Caxias/RJ40

4.1. Apresentando o município de Duque de Caxias/RJ 40

4.2. A proposta de reestruturação do currículo da rede municipal de Duque de Caxias $\quad 42$

4.2.1. Antecedentes 42

4.2.2. Atual reestruturação curricular do Município de Duque de Caxias 45

4.2.3. Reestruturação curricular: texto introdutório 48

5. O que pensam os professores alfabetizadores sobre a reestruturação curricular?

5.1 Eixo 1) Motivações que levaram a SME Duque Caxias/RJ à reestruturação do currículo da rede de ensino

5.2. Eixo 2) Concepções de alfabetização dos professores da rede municipal de educação

5.4. Eixo 3) Conhecimento dos professores sobre as concepções de alfabetização presentes nos documentos curriculares da rede de ensino e na BNCC

6. Considerações finais $\quad 81$

7. Referências 83

8. Anexos 91 


\section{Lista de abreviaturas e siglas}

ANA - Avaliação Nacional da Alfabetização

ANPED - Associação Nacional de Pós-Graduação e Pesquisa em Educação

BNCC - Base Nacional Comum Curricular

DCNS - Diretrizes Curriculares Nacionais

FEBF- Faculdade de Educação da Baixada Fluminense

GE - Grupos de Estudo

IBGE - Instituto Brasileiro de Geografia e Estatística

IDEB - Índice de Desenvolvimento da Educação Básica

INEP - Instituto Nacional de Estudos e Pesquisas Educacionais Anísio

Teixeira

LDB - Lei de Diretrizes e Bases da Educação Básica

MPB - Movimento pela Base

PCNS- Parâmetros Curriculares Nacionais

PISA - Programa Internacional de Avaliação de Estudantes

PME - Plano Municipal de Educação

PNAIC - Programa Nacional de Alfabetização na Idade Certa

PNA - Política Nacional de Alfabetização

PNA - Plano Nacional de Alfabetização

PNE - Plano Nacional de Educação

SAEB - Sistema de Avaliação da Educação Básica 


\section{Introdução}

A formulação e a implementação da Base Nacional Comum Curricular (BNCC) coloca enormes desafios para as redes públicas de ensino Estaduais e Municipais, uma vez que estas redes precisam rever seus currículos escolares, em todas as etapas e segmentos da Educação Básica, para se alinhar às proposições da BNCC. A BNCC foi formulada e implementada com o objetivo de atender aos dispositivos que legislam a Educação Básica, como a Constituição Federal de 1988, a Lei de Diretrizes e Bases da Educação Básica (LDB) e o Plano Nacional de Educação (PNE 2014-2024).

Atendendo a esses dispositivos legais, iniciaram-se, em 2014, as discussões sobre a elaboração da $\mathrm{BNCC}$, que culminou na Resolução $\mathrm{CNE} / \mathrm{CP} \mathrm{n}^{\circ}$ 2, de 22 de dezembro de 2017 - documento que institui e orienta a implantação da BNCC para a Educação Infantil e o Ensino Fundamental. A BNCC foi idealizada com o objetivo de nortear os currículos das redes de ensino Municipais e Estaduais e as propostas pedagógicas das escolas públicas e privadas. Assim, as redes de ensino passaram a rever seus próprios currículos a fim de incorporar os "conhecimentos, as competências e as habilidades" (BRASIL, 2017) estabelecidas pela BNCC para cada etapa da Educação Básica.

$\mathrm{Na}$ esteira desse movimento, o município de Duque de Caxias, localizado na região metropolitana do estado do Rio de Janeiro, iniciou, em 2019, o processo de reestruturação de seu currículo. No entanto, não se tinha clareza, no início deste estudo, sobre o que realmente motivou essa reestruturação. Sabe-se que a rede elaborou seu currículo em 2002 e 2004 e, de lá para cá, esse documento não passou por atualizações e nem reestruturações.

Assim, algumas questões que motivaram e justificaram este estudo foram: Por que a SME/Duque de Caxias resolveu dar início a uma reestruturação curricular em 2019? Essa reestruturação foi motivada pela BNCC ou pela enorme defasagem temporal de mais de 18 anos sem revisão curricular? Quais as percepções dos professores da rede sobre as concepções de alfabetização no currículo ainda vigente e no que está em construção? Quais as concepções de alfabetização que os professores da rede utilizam no processo de alfabetização? Os professores utilizam 
a concepção de alfabetização adotada pelos documentos curriculares da rede Municipal de Ensino? Qual a percepção dos professores em relação à Base Nacional Comum Curricular?

Guiado por essas questões, o presente estudo buscou investigar as razões que motivaram a reestruturação curricular do município de Duque de Caxias e se as concepções de alfabetização dos professores se alinhavam ou não àquelas presentes nos documentos curriculares municipais e nacional.

Também cabe ressaltar que a escolha da etapa da alfabetização justifica-se por se tratar de uma etapa da vida escolar de experiências de significação de códigos linguísticos fundamentais ao desenvolvimento integral do indivíduo. Além disso, a etapa da alfabetização, enquanto política educacional, vem sendo objeto de inúmeras políticas públicas como, por exemplo, o Programa Nacional de Alfabetização na Idade Certa (PNAIC), a Avaliação Nacional da Alfabetização (ANA) ${ }^{1}$, a própria Base Nacional Comum Curricular (BNCC) e a Política Nacional de Alfabetização (PNA), o que evidencia o investimento governamental nesta etapa escolar.

Outro motivo é o que se refere ao meu próprio interesse profissional, uma vez que, enquanto professora alfabetizadora da rede de ensino de Duque de Caxias, participei de algumas etapas desta reestruturação curricular e das discussões acerca das concepções de aprendizagem, particularmente da alfabetização, adotadas neste processo de reformulação do currículo.

Desse modo, considerando a importância que a etapa da alfabetização tem para a formação integral do indivíduo e considerando o currículo como um dos pilares para a qualidade da educação, esta pesquisa se propôs a investigar as concepções de alfabetização presentes nos documentos curriculares, assim como as trazidas pelos professores da rede de ensino de Duque de Caxias.

Pensar nas concepções de alfabetização dos professores e dos documentos curriculares é relevante no atual momento educacional brasileiro, uma vez que a BNCC é uma política curricular nacional de caráter normativo que impulsionou um movimento de revisão/reformulação dos currículos dos entes subnacionais. Isso porque uma das prerrogativas da BNCC é a promoção da igualdade de acesso ao

\footnotetext{
${ }^{1}$ Tanto a ANA como o PNAIC foram descontinuados em 2016 e em 2018, respectivamente. No entanto, ambas as políticas são esforços importantes do governo federal para a garantia da alfabetização das crianças.
} 
conhecimento científico em todo o território nacional. Ou seja, a BNCC defende a ideia de que a implementação de um currículo comum a todo o território nacional contribui para a promoção de uma educação de qualidade para todas as crianças, independentemente da condição socioeconômica ou da etnia, assegurando, pelo currículo, o direito a aprendizagens consideradas essenciais para a formação cidadã (BRASIL, 2017). Por isso, tais aprendizagens devem ser implementadas em todas as escolas brasileiras, inclusive nas escolas particulares.

No entanto, a construção da BNCC foi um processo permeado por resistências, conflitos e tensões, em que muitos profisssionais da educação se posicionaram contrários à formulação de uma base curricular nacional, dentre eles o GT 12 da ANPED.

Com esta temática em tela, o presente estudo tem como objetivo geral compreender as concepções de alfabetização dos professores alfabetizadores da rede municipal de educação de Duque de Caxias/RJ e dos documentos curriculares: Pressupostos Teóricos Filosóficos (formulado em 2002), Propostas Pedagógicas (elaborado em 2004, em complementação ao documento Pressupostos Teóricos Filosóficos), Reestruturação curricular; texto introdutório (em elaboração) e a BNCC. Dentre os objetivos específicos, o estudo busca:

1 - Compreender os motivos que levaram a SME/Duque de Caxias a reestruturar o currículo da rede de ensino;

2 - Analisar quais são as concepções de alfabetização dos documentos curriculares;

3 - Analisar quais são as concepções de alfabetização dos professores da rede municipal de educação;

4 - Cotejar as concepções de alfabetização dos professores com as concepções de alfabetização dos documentos curriculares.

Para atingir esses objetivos, o estudo fez uso de uma abordagem metodológica qualitativa, por meio de duas técnicas de coleta de dados. A primeira foi a análise dos documentos curriculares já mencionados e a segunda foi a realização de entrevistas, a partir de roteiros semiestruturados, com professores alfabetizadores e coordenadores pedagógicos da rede de ensino. Em decorrência da pandemia do novo coronavírus, as entrevistas foram realizadas na modalidade online, por meio da plataforma Google Meet.

As entrevistas semiestruturadas foram gravadas e analisadas a partir de 
Bardin (1977, p. 38), por meio de uma técnica denominada análise de conteúdo, definida como:

Um conjunto de técnicas de análise das comunicações que utiliza procedimentos sistemáticos e objetivos de descrição do conteúdo das mensagens, cuja intenção é a inferência de conhecimentos relativos às condições de produção (ou, eventualmente, de recepção), inferência esta que recorre a indicadores (quantitativos ou não).

Assim, a pesquisa foi dividida em duas etapas: a primeira se debruçou sobre a análise dos documentos curriculares e a segunda focalizou na realização e na análise das entrevistas semiestruturadas. Por meio de uma técnica denominada bola de neve, o estudo selecionou cinco profisssionais da educação, sendo dois professores alfabetizadores, uma professora da sala de leitura e dois orientadores pedagógicos.

A análise das entrevistas à luz de Bardin (1977) nos permitiu a exploração de três aspectos ou eixos de análise: Eixo 1) Motivações que levaram a SME/Duque Caxias/RJ à reestruturação do currículo da rede de ensino; Eixo 2) Concepções de alfabetização dos professores da rede municipal de educação; Eixo 3) Conhecimento dos professores sobre as concepções de alfabetização presentes nos documentos curriculares da rede de ensino e na BNCC. Esses eixos serão melhor apresentados e discutidos no capítulo 4.

Assim, para a apresentação e para a discussão dos resultados, o trabalho encontra-se dividido em quatro capítulos mais esta introdução e as considerações finais. O capítulo 1, intitulado "Concepções de alfabetização na educação brasileira", buscou apresentar uma breve revisão da literatura sobre o tema, bem como os conceitos de alfabetização, letramento, métodos sintéticos, analíticos, mistos e, também, as concepções de construtivismo e sociointeracionismo.

No capítulo 2, "Concepções de alfabetização presentes na BNCC", analisamos o tópico referente ao ensino fundamental - anos iniciais - do documento curricular nacional, procurando encontrar elementos que nos permitam identificar as concepções de aprendizagem e de alfabetização subjacentes ao documento.

No capítulo 3, “A atual reestruturação curricular do município de Duque de Caxias/RJ", foram analisados os três documentos curriculares da rede de ensino, 
bem como as concepções de alfabetização nesses documentos.

No quarto e último capítulo, com o título "Alfabetização e reestruturação curricular: o que pensam os professores alfabetizadores?", foi possível, por meio de entrevistas realizadas, entender as concepções de alfabetização dos professores alfabetizadores e dos coordenadores pedagógicos da rede municipal de educação de Duque de Caxias e ensaiar algumas aproximações com os documentos curriculares, em especial, os municipais.

Por fim, apresentamos algumas considerações finais, sintetizando os principais achados da pesquisa. 


\section{2}

\section{Concepções de alfabetização na educação brasileira}

Este capítulo apresenta uma breve revisão de literatura sobre os métodos de alfabetização mais difundidos no Brasil. As relações entre metodologias de alfabetização e o desenvolvimento linguístico dos estudantes desde a primeira infância têm relevância e consonância com o objeto proposto neste estudo pela aproximação com aquilo que se faz nas realidades das escolas brasileiras, em especial as escolas do município de Duque de Caxias/RJ.

A alfabetização é um dos temas mais complexos dentro da educação ao longo da história e das relações institucionalizadas de ensino e, neste capítulo, buscou-se realizar uma revisão das concepções históricas de alfabetização e de seus desdobramentos na educação brasileira. Assim, pensar em alfabetização envolve muitos debates, uma vez que o tema está presente não apenas na sala de aula e na escola, como também na formulação e na implementação de políticas públicas de formação de professores alfabetizadores como, por exemplo, o Programa Nacional de Alfabetização na Idade Certa (PNAIC) e nas políticas curriculares, como a atual Base Nacional Comum Curricular (BNCC).

No campo acadêmico, o tema é bastante recorrente e, ainda hoje, inúmeras pesquisas continuam a se debruçar sobre esta temática no intuito de compreender as razões dos altos índices de analfabetismo e/ou analfabetismo funcional e os déficits de aprendizagem dos estudantes brasileiros. Desse modo, a aprendizagem da leitura e da escrita, especialmente aquela que se realiza nos primeiros anos de escolaridade, vem sendo muito discutida.

Em 2015, o Instituto Nacional de Estudos e Pesquisas Educacionais Anísio Teixeira (INEP) divulgou os resultados da Avaliação Nacional da Alfabetização $(\mathrm{ANA})^{2}$ e evidenciou que, no universo 2,5 milhões de estudantes matriculados nos primeiros anos de escolaridade, uma em cada cinco crianças ainda não haviam desenvolvido a capacidade autônoma de ler e escrever. Outro aspecto a ser considerado é que, segundo o INEP, 450 mil estudantes brasileiros no final do terceiro ano do ciclo de alfabetização não conseguiam localizar informações

2 Disponível em: http://portal.inep.gov.br/educacao-basica/resultadosda-ana-2016-por-estados. Acesso em 10 mai. de 2020. 
simples em alguns gêneros textuais como, por exemplo, bilhetes, convites e cartazes (INEP, 2015).

Segundo Mortatti (2004), o baixo desempenho dos alunos na aquisição da leitura e da escrita não pode ser visto como um problema atual, mas, sim, como um problema histórico que envolve a falta de um projeto de médio e longo prazo na educação brasileira. De acordo com a autora:

Decorridos mais de cem anos desde a implantação, em nosso país, do modelo republicano de escola, podemos observar que, desde essa época, o que hoje denominamos "fracasso escolar na alfabetização" se vem impondo como problema estratégico a demandar soluções urgentes e vem mobilizando administradores públicos, legisladores do ensino, intelectuais de diferentes áreas de conhecimento, educadores e professores (2004, p. 6).

Essa mobilização se deve, principalmente, aos resultados insatisfatórios das avaliações em larga escala (SAEB, Prova Brasil, PISA, avaliações estaduais etc.) que vem, recorrentemente, evidenciando o baixo desempenho dos alunos em várias etapas do sistema escolar. A partir disso, a etapa da alfabetização passou a ganhar especial relevância junto a estudiosos do campo e a gestores públicos educacionais, por se entender que a não alfabetização das crianças compromete sua trajetória escolar e a sua formação cidadã.

A principal temática dos estudos sobre a alfabetização refere-se aos métodos empregados nas práticas pedagógicas cotidianas das escolas. Para Soares (2004) e Boto (2019), a utilização de diferentes métodos de alfabetização, no Brasil, tem uma trajetória histórica marcada por rupturas e continuidades e por uma busca permanente de padronização de ações pedagógicas em todo território nacional e pouco relacionada com as referências regionais em termos de linguagens, culturas e perspectivas de formação. Compreende-se que a história da alfabetização não é linear, por isso há a coexistência de métodos de alfabetização e o reaparecimento/desaparecimento constante de determinados métodos.

Considera-se que, mesmo nos casos em que o professor não lança mão de um modo oficial de um método de alfabetização, este tem como fundamentos pressupostos teóricos que direcionam sua prática. Nesse sentido, as concepções de alfabetização são múltiplas e variam de pressuposto para pressuposto teórico, ou seja, os métodos sejam eles sintéticos, analíticos e suas dimensões e suas 
especificidades não se dão de maneira neutra, descolada de fundamentos teóricos, mas todos eles estão ligados as concepções ideológicas, filosóficas, epistemológicas e não se dão de modo estanque, uma vez que a práxis docente é histórica e em movimento.

Além da busca por padronizações, os métodos de alfabetização não são práticas neutras (SOARES, 2004). Ao contrário disso, os métodos empregados são fundamentados por concepções de alfabetização que se materializam nas práticas pedagógicas de alfabetização. A discussão dessas concepções se assenta basicamente em duas grandes correntes teóricas: a concepção mecanicista subdividida em: métodos sintéticos (soletração e/ou alfabético, silábico e fônico) e os métodos analíticos (palavração, sentenciação e global), e a outra concepção advém das ideias da psicogenética e da psicolinguística, que, segundo Soares (2004, p. 89), reconhece a língua em suas dimensões históricas, culturais e sociais:

\begin{abstract}
Uma concepção associacionista do processo de aquisição da escrita considera o método fator determinante da aprendizagem, já que seria por intermédio da exercitação de habilidades hierarquicamente ordenadas que a criança aprenderia a ler e a escrever; uma concepção psicogenética, ao contrário, considera ser o aprendiz o centro do processo, já que o vê como sujeito ativo que define seus próprios problemas e constrói, ele mesmo, hipóteses e estratégias para resolvê-los.
\end{abstract}

Nesse sentido, a partir das concepções psicogenéticas e psicolinguísticas, o aprendizado da leitura e da escrita "não consiste numa simples imitação mecânica da escrita utilizada por adultos, mas numa busca de compreender o que é a escrita e como funciona", Soares (2004, p. 90).

Assim, toda ação durante a práxis pedagógica de alfabetização, está sujeita a fatores de natureza cultural, regionais, filosóficas em pleno movimento, e, portanto, influência diretamente em qualquer método. Assim todo método fundamentado em pressupostos anteriores encontra na historicidade do tempo presente, dimensões a serem consideradas, e por vezes, modificam dialeticamente o próprio método. Então, pode se falar em concepções de alfabetização associacionista e psicogenética, que estão presentes dentro destes métodos, e contínuas revisões que se dão em todas as fases do processo de alfabetização. 
Para Mortatti (2006, p. 4), é possível dividir a historiografia dos processos de alfabetização na escola pública brasileira em quatro grandes momentos: (1) o da "metodização do ensino da leitura"; (2) o da "institucionalização do método analítico"; (3) o da "A alfabetização sob medida"; (4) e o da "Alfabetização: construtivismo e desmetodização".

O primeiro momento, da "metodização do ensino da leitura", foi caracterizado pelo predomínio do ensino da leitura/escrita através dos "métodos de marcha sintética", ou seja, da "parte" para o "todo". Com isso, buscou-se partir "da soletração (alfabético), iniciando com o nome das letras; fônico (partindo dos sons correspondentes às letras); e da silabação (emissão de sons), partindo das sílabas" (MORTATTI, 2006, p. 36). Conforme a autora (2006), o Método Sintético seria precedido da apresentação de unidades menores da própria língua, ou seja, de letras, depois, de sílabas, de palavras, de frases e de textos. Também de acordo com Mortatti (2006), outro método integrante desse primeiro momento da historiografia dos processos de alfabetização é o Método Fônico, que propõe o ensino a partir da correspondência entre a letra (grafema) e o som (fonema), dando ênfase à dimensão sonora da língua e à sua grafia.

O que se pode observar no Método Sintético de aprendizagem da leitura e da escrita é que este ocorre de forma linear, partindo das dimensões mais simples, com a identificação da letra, até chegar à estrutura mais complexa, que seria a leitura do próprio texto. Ressalta-se que, dessa maneira, o que inicialmente envolvia a simples decodificação e codificação das letras, passaria para uma fase mais avançada que corresponde não apenas ao conhecimento das sílabas, mas também à leitura do texto.

Os métodos sintéticos seguem a marcha que vai das partes para o todo. Na história dos métodos sintéticos temos a eleição de princípios organizativos diferenciados que privilegiam a decoração de sinais gráficos e as correspondências fonográficas. Essa tendência compreende o método alfabético que toma como unidade a letra; o método fônico que toma como unidade o fonema e o método silábico que toma como unidade um segmento fonológico mais facilmente pronunciável, que é a sílaba. De maneira geral parece que a escolha por apenas um caminho para sistematização das relações fonema/grafema a letra, o fonema ou a sílaba, é que diferencia o tratamento em torno das correspondências fonográficas (FRADE, 2007, p. 22). 
Portanto, o Método Sintético abarca três metodologias ou dimensões, (1) soletração e/ou alfabético, (2) silábico e (3) fônico. O Método Sintético esteve e está presente na história dos processos de ensino-aprendizagem e etapas escolares que objetivam a alfabetização. Destaca-se que há uma diferença entre o método fônico e uma abordagem de habilidades fonológicas no processo de alfabetização. Isso porque, em todos os métodos de alfabetização, em algum momento, as relações entre fonemas e grafemas surgem inevitavelmente, dada as representações do sistema linguístico escrito e falado.

Entretanto, o que caracteriza o método fônico é uma abordagem central em que os sons da língua são a chave da alfabetização e a tomada de consciência, pelo alfabetizando, dessas relações em que se toma como unidade de trabalho o fonema, o que torna o processo de aprendizado da língua muito complexo. $\mathrm{O}$ fonema aparece no método fônico como uma unidade ideal da língua (CAPOVILLA, 2007).

Outra discussão relevante é sobre a consciência fonológica nas atividades de alfabetização, uma vez que essas, independentemente do método, têm um papel central nesse processo.

Isso porque, conforme Capovilla (2007), no método fônico, a linguagem escrita tem como fundamento a experiência em que o aluno ouve e vê o que está escrito numa correspondência oral e visual sobre a palavra, na qual ampliam-se as experiências para outras dimensões como, por exemplo, as dimensões tácteis em que texturas são utilizadas para representação das letras e das palavras e, também, dimensões cinestésicas em que o aluno constrói movimentos desenhados sobre a própria letra.

Além disso, no método fônico, os movimentos e as posições labiais surgem como fundamentais na emissão do som e na fonoarticulação do que está escrito, tornando a dimensão fonoarticulatória necessária para o processo de alfabetização. Com isso, o ensino-aprendizado desenvolvido a partir deste método inicia-se com a aprendizagem dos sons mais fáceis para os sons mais difíceis, ou seja, com o som e a letra das vogais, isoladamente, e, gradativamente, com a introdução das consoantes simples para as mais complexas - o mesmo ocorre quando uma formação correlaciona sílabas e palavras.

De acordo com Capovilla (2007), as abordagens preconizadas pelo método fônico ampliam as experiências de aprendizagem dos métodos tradicionais (CAPOVILLA, 2007). Apesar disso, Boto (2019) alerta que o estruturalismo por 
trás do método fônico não auxilia a consolidação mental das representações daquilo que é falado e ouvido, uma vez que muitas letras têm o mesmo som e muitas palavras são resultantes de encontros interlinguísticos e, até mesmo, empréstimos linguísticos culturais de outras línguas. De todo modo, a decodificação grafofonêmica e a codificação fonografêmica caminham lado a lado no desenvolvimento e no aprendizado da língua escrita na perspectiva metodológica fônica (BOTO, 2019).

O segundo momento apontado por Mortatti (2006), da "institucionalização do Método Analítico”, faz o movimento inverso ao do Método Sintético: parte das unidades mais complexas da língua como textos, frases e palavras, até chegar, analiticamente, às subunidades da língua (sílaba, letras e som). Nos Métodos Analíticos, as unidades apresentadas inicialmente são unidades de significado, sejam elas palavras, frases ou textos. Assim, os Métodos Analíticos partem de unidades maiores para as unidades menores, ou seja, do 'todo' para a 'parte'. Para Mortatti (2006, p. 7), “o método analítico, sob forte influência da pedagogia norteamericana, baseava-se em princípios didáticos derivados de uma nova concepção — de caráter biopsicofisiológico — da criança, cuja forma de apreensão do mundo era entendida como sincrética".

Assim como os Métodos Sintéticos, os Métodos Analíticos também sofreram variações influenciadas pelo entendimento sobre o que seria a análise do "todo". O Método Analítico desdobrou-se em métodos de 'palavração', 'sentenciação' e 'global', que se diferenciam pelo ponto de partida no processo de ensino e aprendizagem da leitura e da escrita, no qual "o todo" pode ser a palavra, a frase ou o texto como unidade maior de análise. Segundo Frade (2007, p. 26), “o método global integra o conjunto dos métodos analíticos que orientam no sentido do todo para as partes."

Para Frade (2007), o método global, enquanto subdivisão dos Métodos Analíticos, surgiu como uma estratégia de identificação visual da palavra que, por meio de diferentes experiências, provavelmente a partir do século XVII, surge como uma proposta mais econômica do processo de alfabetização, uma vez que o aluno estaria imerso no significado das palavras e não apenas em suas unidades menores. Dessa perspectiva, a proposição metodológica envolve a totalidade do texto, que é resultado de elementos menores. Por isso, esse método envolve a correspondência 
entre letra e som culturalmente adquirida nas experiências sociolinguísticas desde a infância e, posteriormente, canalizada para a significação do texto no contexto.

Segundo Oliveira (2012), o método global parte de unidades como textos, sentenças e palavras que fazem sentido para criança e, a partir daí, avança numa amplitude que contempla progressivamente experiências mais criativas na construção coletiva do texto. Ao mesmo tempo, o método global é associado a práticas criativas de interação do leitor com o texto não apenas focada na sua decodificação mecânica. Com isso, jogos, brincadeiras, proposições lúdicas, significações histórico-literárias compõem práticas de alfabetização alinhadas a esta abordagem.

Embora muitos entendam que o método global avança em relação aos Métodos Sintéticos, em especial ao método fônico, Soares (2016) alerta que a difusão do método global em diferentes países, no século XX, fez emergir estudos que demostraram que a aplicação deste método implica um ensino mecanizado e repetitivo, sendo desinteressante para o aluno e pouco eficaz para a consolidação da alfabetização do educando.

Destarte, surge o terceiro momento, definido por Mortatti (2006) como "A alfabetização sob medida", que é caracterizado pelo questionamento da eficácia dos Métodos Analíticos e pela tentativa dos professores em buscar novas propostas pedagógicas para tentar solucionar os problemas no ensino da leitura e da escrita. Nessa busca por solução no processo da alfabetização, começaram a surgir propostas de conciliação dos Métodos Sintéticos com os Métodos Analíticos, formando, assim, o Método Misto, que se caracteriza pelo ensino, simultâneo, das partes menores das subunidades da língua e do "todo" (unidades maiores da estrutura da língua). Por exemplo, partir da 'palavra' para 'frase' e para o 'texto' e, ao mesmo tempo, decompor as sílabas das palavras. Mortatti (2006) ressalta a influência dos estudos da didática e da psicologia social para a alfabetização neste terceiro momento, pois, segundo a autora, é através dos estudos da didática e da psicologia social que começaram a se difundir orientações sobre "como ensinar", "quem ensinar", "período preparatório" e "nível de maturidade das crianças que são distribuídas em classes homogêneas" Mortatti (2006, p .9).

De acordo com Soares (2004), a trajetória dos métodos de alfabetização se assenta em concepções mecanicistas, advindas de correntes teóricas empiristaassociacionistas, nas quais o processo de apropriação da leitura e da escrita é 
fragmentado, uma vez que a língua é vista como um conhecimento externo e mecânico, descontextualizado do cotidiano do indivíduo. Nesta perspectiva, a aprendizagem da língua ocorre por meio de memorização e de exercícios repetitivos das palavras e das sílabas descontextualizadas.

Tanto os Métodos Sintéticos quanto os Métodos Analíticos se enquadram nestas concepções mecanicistas e descontextualizadas de ensino da língua e passaram a ser questionados na década de 1980, quando os altos índices de repetência e de evasão nos primeiros anos de escolaridade começaram a ser relacionados à fragilidade do processo de aquisição da leitura e da escrita. Foi neste momento que se iniciou, segundo Mortatti (2000), o quarto momento da historiografia dos processos de alfabetização da escola pública brasileira - a “Alfabetização: construtivismo e desmetodização". É neste momento - meados da década de 1980 - que se começa a difundir, no Brasil, as ideias construtivistas de Jean Piaget. Tais ideias enfatizam que o processo de aquisição do conhecimento ocorre através da interação do indivíduo com o objeto de conhecimento e o meio físico em que vive, num processo contínuo de assimilação e modificação do conhecimento através de esquemas mentais em relação aos objetos. Para Piaget (1987), o conhecimento não é algo linear, nem acumulativo, partindo do princípio de que o que está acomodado de informações e de conhecimentos nos esquemas mentais pode, a qualquer momento, desestabilizar-se, realizando, assim, um novo processo de assimilação e acomodação. Conforme Piaget (1987, p. 15), “conhecer não consiste, com efeito, em copiar o real, mas em agir sobre ele e transformá-lo".

De acordo com Becker (1994), as contribuições de Piaget se configuram como uma teoria e não como um método, o que rompe com as discussões até então feitas sobre os métodos Sintéticos, Analíticos e Mistos. Becker (1994, p. 88-89), então, esclarece que o construtivismo de Piaget é:

Uma teoria, um modo de ser do conhecimento ou um movimento do pensamento que emerge do avanço das ciências e da Filosofia dos últimos séculos. Uma teoria que nos permite interpretar o mundo em que vivemos. No caso de Piaget, o mundo do conhecimento: sua gênese e seu desenvolvimento. Construtivismo não é uma prática ou um método; não é uma técnica de ensino nem uma forma de aprendizagem; não é um projeto escolar; é, sim, uma teoria que permite (re)interpretar todas essas coisas, jogando-nos para dentro do movimento da História - da Humanidade e do Universo. Não se pode esquecer que, em Piaget, aprendizagem só tem sentido na medida em que coincide com o processo de desenvolvimento do 
conhecimento, com o movimento das estruturas da consciência. Por isso, se parece esquisito dizer que um método é construtivista, dizer que um currículo é construtivista parece mais ainda.

De acordo com a teoria construtivista, a criança associa cada letra a um som ou fonema dentro de hipóteses alfabéticas construídas nas relações sociais cotidianas. Desse modo, a concepção de alfabetização construtivista não deve ser compreendida como um método de alfabetização, mas como uma apropriação conceitual da língua escrita dentro de contextos que, significativamente, fazem com que a criança se aproprie da leitura e da escrita por meio de práticas sociais de leitura (SOARES, 2016). Nesta perspectiva de alfabetização, a atuação do educador é ressignificada.

No paradigma construtivista, que busca identificar as hipóteses que a criança constrói sobre a natureza da escrita ao longo de seu desenvolvimento, a atuação do(a) alfabetizador(a) é de acompanhamento do processo de conceitualização da língua escrita pela criança em seu convívio com material escrito, acompanhamento traduzido em provocação e orientação na estruturação, desestruturação, reestruturação de hipóteses e conceitos sobre a língua escrita. $\mathrm{O} / \mathrm{a}$ alfabetizador(a) não propriamente ensina, mas guia a criança em seu desenvolvimento: processos internos que a levam à formulação de hipóteses e à formação de conceitos sobre um objeto de conhecimento com o qual se defronta - a língua escrita (SOARES, 2016, p. 335).

Logo, como apontado por Soares (2016), as hipóteses da escrita se apresentam naquilo que pode ser compreendido como uma consciência fonológica a ser desenvolvida naturalmente por meio da relação com o cotidiano. Nestes processos, cabe ao educador a tarefa de acompanhar e fazer mediações a fim de viabilizar/facilitar, por meio de estímulos diversos, a formulação das hipóteses da escrita. Quanto maior o número de estímulos e melhor a qualidade desses estímulos, mais eficaz será o desenvolvimento alfabético da criança.

Um estudo muito importante, desenvolvido por Ferreiro e Teberosky (1985), contribuiu para a compreensão da teoria construtivista. Este estudo, denominado Psicogênese da Língua Escrita, foi fundamentado na teoria piagetiana e investigou o processo de construção da escrita infantil, procurando compreender como a criança desenvolve esse processo de construção e reconstrução da escrita. Ferreiro e Teberosky (1985) apontaram quatro etapas, intituladas de hipóteses ou níveis de 
desenvolvimento da escrita: (1) "nível pré-silábico"; (2) "nível silábico”; (3) "nível silábico-alfabético"; (4) "nível alfabético".

No nível pré-silábico, a criança ainda não realiza a correspondência entre as 'letras' e os 'sons' e, por isso, combina letras, desenhos, sinais e números em sua escrita. Em seguida, na tentativa de escrever, relaciona o conhecimento das letras convencionais por meio da exploração de outros critérios, tais como a variação da quantidade de letras de uma palavra para outra.

No nível silábico, a criança começa a entender a correspondência entre o grafema (letra) e o fonema (som), escrevendo uma letra ou símbolo para cada sílaba, tendo ou não o valor sonoro convencional. Ou seja, nessa fase, há uma tentativa de escrever a palavra relacionando a quantidade de letras com a linguagem oral. Segundo Ferreiro (1990, p. 86), “(..) o momento da chamada hipótese silábica seria o momento da primeira teorização, que permite dar conta, pela primeira vez, de todas as produções”, tendo em vista, também, conforme Ferreiro (1990, p. 266), que a "primeira solução oferecida pelas crianças é uma divisão da palavra em termos de suas sílabas".

Já o nível silábico-alfabético é a fase de transição da escrita, pois, na tentativa de escrever, a criança oscila entre o nível silábico e o alfabético, ora utilizando uma letra para representar a sílaba, voltando ao nível silábico, ora, na tentativa de acrescentar uma letra, busca a correspondência entre o fonema e o grafema.

No nível alfabético, a criança faz a correspondência entre as letras e seu valor sonoro, sendo que cada letra corresponde a uma unidade sonora da palavra. Além disso, a criança compreende a função da escrita e aprimora a grafia correta das palavras.

A explicação desses quatro níveis apresentados por Ferreiro e Teberosky (1985) é sintetizada por Oliveira da seguinte forma:

A princípio, na hipótese pré-silábica, as crianças não relacionam as formas gráficas com segmentos orais das palavras, no entanto, logo após, começam a formular hipóteses sobre a fonetização da escrita. Num primeiro momento, esse critério não corresponde à escrita convencional. As crianças costumam representar cada parte da palavra por apenas um sinal gráfico (hipótese silábica). Em seguida, caminham para o período alfabético, no qual reconhecem que as letras representam fonemas da língua, quando compreendem o 
princípio fundamental de organização do código sobre o qual a nossa língua se constitui (2012, p. 109).

Foi por meio do estudo de Ferreiro e Teberosky (1985) que esta nova concepção de alfabetização - o construtivismo - começou a ser difundida no Brasil. Portanto, a aquisição do sistema da leitura e escrita não é apenas um processo de codificar/decodificar as letras e memorizá-las. Ao contrário disso, a aquisição desse sistema envolve um processo complexo de construção e reinvenção da escrita.

No que se refere ao processo de alfabetização, a concepção psicogenética da aquisição do sistema de escrita e as contribuições das ciências linguísticas, particularmente da Psicolinguística, "transformaram" o conceito de sujeito aprendiz da escrita - não mais um sujeito que aprende a escrever por imitação, por repetição, por associação, copiando e reproduzindo letras, sílabas, palavras, frases, - em um sujeito que aprende atuando com e sobre a língua escrita, buscando compreender o sistema, levantando hipóteses sobre ele, com base na suposição de regularidades nele, submetendo à prova essas hipóteses e supostas regularidades. Altera-se, assim, radicalmente, a orientação do processo de aprendizagem e o significado das dificuldades enfrentadas pela criança nesse processo (SOARES, 2008, p. 61).

Nesta mudança de paradigma, Ferreiro e Teberosky (1985) enfatizam que é preciso tratar os métodos de alfabetização partindo das próprias concepções das crianças a respeito do sistema de escrita, para que se crie as condições que permitam à criança compreender a escrita não apenas como um conjunto de palavras, mas como um conjunto de concepções acerca da língua que ultrapassa a mera codificação e decodificação de palavras. Nesse sentido, a preocupação das autoras não estava em pensar meramente um "método", mas, principalmente, os processos mentais de cognição envolvendo a própria linguagem escrita e falada.

A concepção da aprendizagem (entendida como um processo de obtenção de conhecimento) inerente à psicologia genética supõe, necessariamente, que existem processos de aprendizagem do sujeito que não dependem de métodos (processos que, poderíamos dizer, passam "através" dos métodos). O método (enquanto ação específica do meio) pode ajudar ou frear, facilitar ou dificultar, porém não criar aprendizagem. A obtenção do conhecimento é um resultado da própria atividade do sujeito. [...] Um sujeito ativo é um sujeito que compara, exclui, ordena, categoriza, reformula, comprova, formula hipóteses, reorganiza, etc., em ação interiorizada (pensamento) ou em ação efetiva (segundo seu nível de desenvolvimento). Um sujeito que está realizando algo materialmente, porém segundo as instruções 
ou o modelo para ser copiado, dado por outro, não é, habitualmente, um sujeito intelectualmente ativo (FERREIRO E TEBEROSKY, 1985, p. 28-29).

Assim, a partir dos estudos de Ferreiro e Teberosky (1985), as discussões sobre os Métodos Sintéticos, Métodos Analíticos e Métodos Mistos ficam menos em evidência e uma nova concepção "que compreende a criança como um sujeito cognoscente, que pensa e desenvolve hipóteses sobre o sistema de escrita, antes mesmo de frequentar a instituição escolar" (MUYLAERT, 2020, p. 9-10) passa a se destacar. A alfabetização é, portanto, muito mais do que um processo de codificação/decodificação das letras. Trata-se de um processo de construção do próprio conhecimento sobre a leitura e a escrita, permeado por diversas "dificuldades conceituais semelhantes às da construção do sistema e, por isso, podese dizer que a criança re-inventa esse sistema" (FERREIRO e TEBEROSKY, 1985 p. 53).

Concomitante e complementarmente à difusão do construtivismo de Piaget, o conceito de sociointeracionismo e de teoria histórico cultural, é, de acordo com Prestes (2010) oriundo dos estudos de Vygotsky (2001) também passou a ser discutido no âmbito educacional brasileiro. O sociointeracionismo ou teoria histórico cultural enfatiza que o conhecimento é construído através da interação do indivíduo em sociedade, desenvolvendo-se no processo histórico, cultural e linguístico. De acordo com Vygotsky (2001, p. 33), “o caminho do objeto até a criança e desta até o objeto passa através de outra pessoa. Esta estrutura humana complexa é fruto de um processo de desenvolvimento profundamente enraizado nas ligações entre história individual e história social". $\mathrm{Na}$ perspectiva sociointeracionista ou sócio histórico cultural de Vygotsky (2010), a aprendizagem ocorre através do envolvimento das interações sociais entre as crianças e o professor, num processo de movimento mútuo, no qual ocorre a modificação e a reelaboração do conhecimento. No sociointeracionismo, o princípio chave está na interação do indivíduo em sociedade enquanto caminho de acesso ao conhecimento. Com isso, a alfabetização não é um processo direto, mas mediado, em que a constituição da subjetividade se dá.

Outro conceito abordado por Vygotsky (2010), difundido no processo de ensino e aprendizagem, é chamado de Zona de Desenvolvimento Proximal (ZDP), que define aquelas funções que "ainda não amadureceram, mas que estão em 
processo de maturação, funções que amadurecerão" (Vygotsky, 2010, p. 98). Este conceito, trazido para os processos de alfabetização, envolve uma proposta pedagógica que possibilita a mediação do professor com a criança e desta com seus colegas. Desse modo, quanto maior for a quantidade e a qualidade das interações das crianças com os seus pares e com o professor, maior será a autonomia da criança para a realização das atividades de leitura e de escrita.

Cabe destacar que as discussões que envolvem a alfabetização podem envolver diferentes teorias, perspectivas, concepções, métodos. Dentre as mais relevantes, estão as perspectivas construtivistas e sociointeracionistas, apresentadas neste estudo, que, como pode-se identificar, não competem entre si, mas se complementam. Isso porque o processo de aprendizagem da escrita não está descolado de seu contexto social e das interações que a criança estabelece com o seu meio social. Ao contrário, os processos de reinvenção e de ressignificação da escrita se dão em contextos sociais específicos, por meio das múltiplas e diversas interações. Por isso, a tarefa de mediação do professor pode se fundamentar no construtivismo numa perspectiva sociointeracionista (SOARES, 2016).

No construtivismo, o processo de aprendizagem envolve a construção de conceitos, numa relação de assimilação e acomodação de conceito linguísticos e no processo evolutivo da aprendizagem em que se busca, na relação de ensinoaprendizagem, autonomia, adaptação e interatividade. Segundo Soares (2016), dentre as principais características da teoria epistemológica, estão a proposição de situações-problema que envolvam a formulação de hipóteses, a investigação e/ou a comparação; também envolve a construção de caminhos epistemológicos na solução de problemas; construção e adaptação dos conteúdos curriculares ao nível do aprendiz.

No caso das perspectivas sociointeracionistas de Vygotsky, como na perspectiva construtivista de Piaget, “(...) o ponto comum entre Piaget e Vygotsky está no fato de que ambos se opõem ao associacionismo empirista e ao idealismo racionalista." (KRAMER e SOUZA, 1991, p.76). Ambas as teorias aproximam-se da compreensão de que os indivíduos interagem com conhecimento, numa relação de troca no processo de aprendizagem. Diferentemente, na concepção associacionista “(...) o professor é o centro do processo educativo e sua tarefa limita-se na a expor conceitos de forma objetiva." (KRAMER e SOUZA, 1991, p. 76) As abordagens sociointeracionista e construtivista envolvem um conjunto de 
potencialidades que permeiam experiências educacionais diversas e podem ser complementares nas práticas pedagógicas de alfabetização no interior das salas de aula.

Caminhando pela historiografia dos processos de alfabetização, mais recentemente, a partir da década de 1990, os estudos brasileiros sobre a alfabetização passaram a incorporar à discussão o conceito de letramento, que compreende a ação de ler e de escrever como uma prática social na qual os sujeitos se apropriam da escrita com o intuito de agir e interagir nos diversos contextos sociais que frequentam.

O termo letramento tem sua originalidade na língua inglesa, no termo literacy:

(...) literacy é o estado ou condição que assume aquele que aprende a ler e escrever. Implícita nesse conceito está a ideia de que a escrita traz consequências sociais, culturais, políticas, econômicas, cognitivas, linguísticas, quer para o grupo social em que seja introduzida, quer para o indivíduo que aprenda a usá-la (SOARES, 1989, p. 17).

Para Soares (2004), a alfabetização e o letramento são processos inseparáveis, porém precisam ser analisados separadamente para melhor compreendê-los:

\begin{abstract}
Alfabetização e letramento são, pois, processos distintos, de natureza essencialmente diferente; entretanto, são interdependentes e mesmo indissociáveis. A alfabetização - a aquisição da tecnologia da escrita - não precede nem é prérequisito para o letramento, isto é, para a participação em práticas sociais de escrita, tanto assim que analfabetos podem ter certo nível de letramento: não tendo adquirido a tecnologia da escrita, além disso, na concepção psicogenética de alfabetização que vigora atualmente, a tecnologia da escrita é aprendida não, como em concepções anteriores, com textos artificialmente para a aquisição das técnicas de leitura e de escrita, mas através de atividades de letramento, isto é, de leitura e produção de textos reais, de práticas sociais de leitura e de escrita (SOARES, 2004, p. 5-6).
\end{abstract}

No processo de aquisição da linguagem, especialmente no que envolve a leitura e a escrita, a interação linguística deve abarcar múltiplas experiências dialetais e cotidianas, não se fechando nas relações com o livro didático ou na sala 
de aula. De acordo com Soares (1989, p. 15), "alfabetizar significa adquirir a habilidade de decodificar a língua oral em língua escrita (...)", enquanto o letramento seria "muito mais amplo do que a alfabetização (...)", ou seja, "a condição de interação com diferentes gêneros e tipos de leitura e escrita, com diferentes funções envolvendo tais práticas” (SOARES, 1989, p. 20).

Segundo Soares e Maciel (2000), a partir das décadas de 1980 e 1990, com a adesão de práticas construtivistas de alfabetização, houve uma desmetodização nos processos de ensino-aprendizagem da alfabetização, uma vez que as propostas construtivistas se aproximavam das relações entre a língua e o cotidiano dos indivíduos, colocando o foco nos processos de aprendizagem da criança na cultura e no exercício de suas linguagens locais.

Embora se tenha a defesa, por parte de muitos educadores, da concepção construtivista na alfabetização das crianças, os dados do Sistema de Avaliação da Educação Básica (Saeb) (Brasil, 2017) ${ }^{3}$, apontam que no universo de 1,4 milhão de estudantes, apenas 20 mil conseguiram alcançar as habilidades de leitura e de escrita consideradas adequadas para a conclusão do ensino médio. O baixo desempenho apresentado pelos estudantes nas avaliações de língua portuguesa faz ressurgir, alguns casos, a defesa do Método Fônico entre alguns educadores defendendo como o mais eficaz para a aquisição da leitura e da escrita, o que tensiona não apenas as concepções de aprendizagem construtivistas, como também as ideias subjacentes ao conceito de letramento.

Este tensionamento é vivenciado tanto no chão da escola, nas salas de aula, quanto nas discussões governamentais acerca das políticas educacionais referentes à formação de professores e às diretrizes curriculares.

Neste sentido, o presente estudo procurou compreender as concepções de alfabetização presentes em dois documentos curriculares: a BNCC - política curricular nacional e os documentos curriculares da rede de ensino de Duque de Caxias/RJ. A intenção foi identificar se há, ou não, alinhamentos entre as orientações curriculares da esfera nacional e municipal sobre as concepções de alfabetização. Complementarmente, o estudo entrevistou professores

3Disponível em http://portal.inep.gov.br/artigo//asset_publisher/B4AQV9zFY7Bv/content/saeb2017-revela-que-apenas-1-6-dos-estudantes-brasileiros-do-ensino-medio-demonstraram-niveis-deaprendizagem-considerados-adequados-em-lingua-portug/21206. Acesso em: 22 mai. 2020. 
alfabetizadores da rede de ensino pública de Duque de Caxias para compreender as percepções que esses atores possuem sobre as concepções de alfabetização e o quanto essas percepções se aproximam ou se distanciam dos documentos curriculares.

Os dois capítulos que seguem abordam essa discussão. O primeiro apresenta e discute as concepções de alfabetização nos documentos curriculares; o segundo apresenta as percepções dos professores alfabetizadores sobre as concepções de alfabetização. 


\section{Concepções de alfabetização presentes na BNCC}

A Constituição Federal de 1988 estabeleceu a educação como um direito público subjetivo (DUARTE, 2004), o que, em termos práticos, implicou a obrigatoriedade do Estado em elaborar e em implementar políticas públicas com vistas à garantia desse direito. Dentre os vários aspectos mencionados na $\mathrm{CF} / 88$ sobre a educação brasileira, ganha destaque o estabelecimento do regime de colaboração entre os entes federados na organização dos sistemas de ensino, que envolve muitas questões, dentre elas, o currículo - foco da análise de nosso estudo. Definir o que ensinar nas escolas públicas é uma discussão permeada por diferentes perspectivas que envolve, sinteticamente, duas grandes correntes de pensamento: uma que defende a definição de um currículo que deve ser trabalhado em todos os estabelecimentos de ensino do território nacional e outra que defende a elaboração de diretrizes curriculares que orientem os entes federados e as unidades escolares na construção de seus próprios currículos.

O artigo 210 da Constituição Federal dispõe sobre a fixação de "conteúdos mínimos para o ensino fundamental, de maneira a assegurar formação básica comum e respeito aos valores culturais e artísticos, nacionais e regionais." (BRASIL, 1988). A Lei de Diretrizes e Bases da Educação Nacional (LDB), de 1996, que regulariza a organização da educação brasileira com base nos dispositivos da Constituição Federal, define, em seu artigo $9^{\circ}$, a União como o ente federado responsável por estabelecer, “em colaboração com os Estados, o Distrito Federal e os Municípios, competências e diretrizes para a educação infantil, o ensino fundamental e o ensino médio, que nortearão os currículos e seus conteúdos mínimos, de modo a assegurar formação básica comum”. (BRASIL, 1996). Assim, a LDB estabelece que a definição das diretrizes curriculares deve se dar a partir do regime de colaboração, envolvendo as três esferas governamentais.

A partir deste arcabouço jurídico, o governo federal vem elaborando, desde a década de 1990, políticas curriculares. A primeira delas foram os Parâmetros Curriculares Nacionais (PCNs), que, como o próprio nome diz, se caracterizaram como parâmetros para que as redes de ensino pudessem elaborar seus próprios documentos curriculares. Embora a intenção dos PCNs tenha sido o de 
uniformização e padronização dos conteúdos curriculares nas escolas brasileiras (MARSIGLIA, PINA, MACHADO e LIMA, 2017), o que se verificou, na prática, foi uma pulverização de currículos, com conteúdos diversificados nas redes de ensino e em unidades escolares. Esses currículos, ao invés de seguirem os parâmetros nacionais, basearam-se, principalmente, nos livros didáticos e nas matrizes de referência das avaliações em larga escala. Desta forma, os PCNs foram subutilizados e não se consolidaram como referências para a elaboração dos currículos locais.

Em que pese esta subutilização, os PCNs foram formulados com base na concepção construtivista (BRASIL, 1997) e tiveram uma importante contribuição para a difusão desta concepção nas diversas redes de ensino e unidades escolares.

Sobre as concepções de alfabetização nos Parâmetros Curriculares Nacionais, apresenta-se a psicogênese da língua escrita como sendo revolucionária e o caminho por excelência para a resolução dos problemas de alfabetização no Brasil. Segundo os Parâmetros Curriculares Nacionais (1997, p. 32):

\begin{abstract}
A pesquisa sobre a psicogênese da língua escrita chegou ao Brasil em meados dos anos 80 e causou grande impacto, revolucionando o ensino da língua nas séries iniciais e, ao mesmo tempo, provocando uma revisão do tratamento dado ao ensino e à aprendizagem em outras áreas do conhecimento. Essa investigação evidencia a atividade construtiva do aluno sobre a língua escrita, objeto de conhecimento reconhecidamente escolar, mostrando a presença importante dos conhecimentos específicos sobre a escrita que a criança já tem, os quais, embora não coincidam com os dos adultos, têm sentido para ela. (grifo nosso)
\end{abstract}

Cabe destacar, que a perspectiva construtivista de alfabetização é apresentada no documento como aquela que causou "grade impacto" e "revolucionou" metodologias anteriores. Contudo, a lógica das indicações e organização das práticas para os anos escolares no capítulo que trata da língua portuguesa, não traz, de fato, as perspectivas construtivistas como teoricamente são, especialmente pela lógica monolinguística introduzida nos anos iniciais do Ensino Fundamental.

Embora haja elementos da teoria construtivista nos fundamentos sobre 
práticas e processos de alfabetização, os PCN's mantiveram indicações sobre os processos de ensino-aprendizagem centrados nas disciplinas curriculares oficiais, apesar de introduzir o conceito de interdisciplinaridade em suas abordagens.

Posteriormente, em 2013, há uma nova tentativa do governo federal de “assegurar formação básica comum” (BRASIL, 1996) no território nacional, a partir da elaboração das Diretrizes Curriculares Nacionais (DCNs). Antes de sua publicação, em 2013, as DCN's foram exaustivamente e extensivamente debatidas em vários fóruns de discussão e deu importantes subsídios para as redes de ensino construírem seus próprios currículos. Apesar disso, o documento publicado representou muito mais uma ambiguidade do que um avanço em relação às políticas curriculares nacionais. Isso porque, ao mesmo tempo em que afirmou a obrigatoriedade da implementação das diretrizes em todas as redes de ensino e unidades escolares, também reafirmou a autonomia dos entes federados na formulação de seus próprios currículos, o que acabou fazendo com que as DCNs se tornassem uma versão atualizada dos PCNs. Neste sentido, as DCNs avançaram pouco em relação à implementação de um currículo comum em todo o território nacional, mas conseguiram inovar ao trazer para a discussão sobre alfabetização a ampliação do ensino fundamental de nove anos e o conceito de letramento.

\begin{abstract}
O acesso ao Ensino Fundamental aos 6 (seis) anos permite que todas as crianças brasileiras possam usufruir do direito à educação, beneficiando-se de um ambiente educativo mais voltado à alfabetização e ao letramento, à aquisição de conhecimentos de outras áreas e ao desenvolvimento de diversas formas de expressão (...) (BRASIL, 2013, p. 121).
\end{abstract}

Mais recentemente, em $2017^{4}$, em meio a uma crise política, foi aprovada uma nova política curricular - a Base Nacional Comum Curricular ${ }^{5}$ (BNCC). Com base no arcabouço jurídico educacional brasileiro ${ }^{6}$ e na necessidade de se combater as desigualdades sociais e educacionais, a BNCC foi formulada com o objetivo de garantir a todos os estudantes brasileiros a aprendizagem de conhecimentos

\footnotetext{
${ }^{4}$ Em 2017 foi homologado apenas o documento da BNCC referente à Educação Infantil e ao ensino fundamental. O documento curricular referente ao ensino médio foi homologado em 2018, após a aprovação do Novo Ensino Médio.

5 Portaria n.1.570, de 20 de dezembro de 2017.

${ }^{6}$ Constituição Federal de 1988, Lei de Diretrizes e Bases da Educação Básica (LDB), documentos produzidos na primeira e segunda Conferências de Nacional de Educação (CONAE), ocorridas em 2010 e 2014, respectivamente e Plano Nacional de Educação (PNE).
} 
considerados essenciais para a formação do cidadão. Neste sentido, a BNCC apresenta um conjunto de conteúdos para cada etapa escolar e cada componente curricular que deve ser ensinado a todas as crianças. Esta proposição da BNCC divide opiniões de especialistas do campo da Educação, de agentes políticos e da sociedade civil organizada, em que alguns se posicionam a favor (como o Movimento pela Base - MPB) e outros contra (como a Associação Nacional de PósGraduação e Pesquisa em Educação - ANPED) a sua implementação.

Foge ao escopo deste estudo abordar os pontos de discordância entre os grupos que assumem diferentes posicionamentos frente à BNCC. No entanto, cabe mencionar que seu processo de formulação é alvo de muitas críticas, inclusive daqueles que defendem a implementação de um currículo nacional. Isso porque a crise política vivenciada na época afetou o processo de elaboração da BNCC, sendo que a versão aprovada em 2017, pelo governo de Michel Temer, distancia-se muito das duas primeiras versões, elaboradas ainda no governo de Dilma Rousseff. Esse distanciamento refere-se à mudança na concepção de aprendizagem existente entre as duas primeiras versões e a aprovada. A mudança mais significativa diz respeito à retirada do termo "direito à aprendizagem" e à inclusão de uma proposta de ensino e aprendizagem baseada no desenvolvimento de competências gerais.

Esta mudança foi justificada pela ampliação, nas últimas duas décadas, de instrumentos de avaliação em larga escala nacionais e internacionais e, também, pelas reformas curriculares ocorridas em outros países. Essa mudança de proposta curricular representou uma ruptura com as versões anteriores, o que ocasionou muitas críticas, inclusive de defensores da construção da BNCC.

Em que pese as críticas direcionadas ao processo de elaboração da BNCC, ela foi homologada e, no atual momento, as redes de ensino e as unidades escolares encontram-se diante do desafio de implementá-la nas suas salas de aula.

O documento da BNCC é público e está disponível em um endereço eletrônico ${ }^{7}$ mantido pelo MEC, para o livre acesso de quem estiver interessado. No entanto, embora haja facilidade em acessar o documento, sua leitura e compreensão não são tão fáceis de serem realizadas. $\mathrm{O}$ documento possui 600 páginas e exibe cinco capítulos além da apresentação. São eles: 1 - Introdução; 2 - Estrutura da BNCC; 3 - A etapa da Educação Infantil; 4 - A etapa do ensino fundamental; 5 - A

\footnotetext{
7 http://basenacionalcomum.mec.gov.br/a-base.
} 
etapa do ensino médio.

O capítulo 4 da BNCC é o interesse de análise do presente estudo, pois refere-se aos anos iniciais do ensino fundamental - segmento escolar que engloba o ciclo de alfabetização. Ele encontra-se dividido em 5 tópicos ou seções, a saber: 1 - Área de Linguagens; 2 - Área de Matemática; 3 - Área de Ciências da Natureza; 4 - Área de Ciências Humanas; e, por fim, 5 - Ensino Religioso.

No tópico 1 - Área de Linguagens - há subtópicos ou subseções, sendo que deles, nos interessamos pelo subtópico 4.1.1.1. Língua Portuguesa no Ensino Fundamental - Anos Iniciais: práticas de linguagem, objetos de conhecimento e habilidades, que aborda o currículo referente ao ciclo de alfabetização, apresentando, em linhas gerais, as concepções o fundamentam e, mais detalhadamente, as competências e habilidades que devem ser desenvolvidas.

Um dos principais aspectos identificados no subtópico 4.1.1.1 do documento foi a afirmação de que o processo de alfabetização pode ser concretizado nos dois primeiros anos de alfabetização.

Embora, desde que nasce e na Educação Infantil, a criança esteja cercada e participe de diferentes práticas letradas, é nos anos iniciais $\left(1^{\circ}\right.$ e $2^{\circ}$ anos) do Ensino Fundamental que se espera que ela se alfabetize. Isso significa que a alfabetização deve ser o foco da ação pedagógica (BRASIL, 2017, p. 89).

A definição de um tempo específico para a alfabetização das crianças não é consenso entre os especialistas do campo da Educação e nem mesmo na legislação brasileira educacional. Se, por um lado, a BNCC estabelece o $2^{\circ}$ ano do ensino fundamental para a concretização da alfabetização, a meta 5 do PNE (2014-2024) estabelece o $3^{\circ}$ ano. Já a Política Nacional de Alfabetização (PNA) estabelece como uma diretriz a "priorização da alfabetização no primeiro ano do ensino fundamental” (BRASIL, 2019). Neste sentido, é possível observar um desalinhamento na legislação educacional sobre qual é a etapa escolar adequada para a concretização da alfabetização. Em que pese a dissonância legal sobre esta definição, Ferreiro (1990) destaca que é um equívoco definir o momento de iniciação e de finalização da alfabetização das crianças, uma vez que esta aprendizagem depende muito mais da qualidade e da quantidade dos estímulos e das ocasiões sociais de contato com a linguagem escrita do que com a maturidade da criança. 
Outro aspecto identificado refere-se à ausência de referências às ideias construtivistas, o que indica que a concepção de alfabetização preconizada pelo documento não se fundamenta nesta teoria, como observado nos documentos curriculares anteriores (PCNs e DCNs). Ao contrário disso, o documento parece resgatar as concepções de alfabetização dos Métodos Sintéticos, em especial, o método fônico. Isso aparece quando o documento afirma que

é preciso que os estudantes conheçam o alfabeto e a mecânica da escrita/leitura - processos que visam a que alguém (se) torne alfabetizado, ou seja, consiga "codificar e decodificar" os sons da língua (fonemas) em material gráfico (grafemas ou letras), o que envolve o desenvolvimento de uma consciência fonológica (dos fonemas do português do Brasil e de sua organização em segmentos sonoros maiores como sílabas e palavras) e o conhecimento do alfabeto do português do Brasil em seus vários formatos (letras imprensa e cursiva, maiúsculas e minúsculas), além do estabelecimento de relações grafofônicas entre esses dois sistemas de materialização da língua (BRASIL, 2017, p. 89-90).

Como observamos no trecho acima, o alfabetizado é aquele que consegue "codificar e decodificar os sons da língua (fonemas) em material gráfico (grafemas ou letras)", recolocando na agenda curricular a dimensão mecanicista do processo de alfabetização. Embora o documento reconheça a diversidade linguística do país, tal aspecto parece não ser relevante no processo de alfabetização das crianças, uma vez que o foco está no desenvolvimento de habilidades de codificação e decodificação, denominadas de transcodificação linguística (BRASIL, 2017, p. 90).

O documento parece preconizar um aprendizado linear que parte das dimensões mais simples, com a identificação da letra, até chegar à estrutura mais complexa, que seria a leitura do próprio texto. O que inicialmente envolve a simples decodificação e codificação das letras, vai ganhando progressão que passa pelo conhecimento das letras, sílabas, frases, até alcançar o texto.

(...) alfabetizar é trabalhar com a apropriação pelo aluno da ortografia do português do Brasil escrito, compreendendo como se dá este processo (longo) de construção de um conjunto de conhecimentos sobre o funcionamento fonológico da língua pelo estudante. Para isso, é preciso conhecer as relações fono-ortográficas, isto é, as relações entre sons (fonemas) do português oral do Brasil em suas variedades e as letras (grafemas) do português brasileiro escrito. Dito de outro modo, conhecer a "mecânica" ou o funcionamento da escrita 
alfabética para ler e escrever significa, principalmente, perceber as relações bastante complexas que se estabelecem entre os sons da fala (fonemas) e as letras da escrita (grafemas), o que envolve consciência fonológica da linguagem: perceber seus sons, como se separam e se juntam em novas palavras etc. (BRASIL, 2017, p. 90).

Ademais, o documento aponta que a aprendizagem das relações fonografêmicas (codificação e decodificação de letras e sons) é complementada pela ortografização (conhecimento da ortografia do português) e pelo aprendizado da estrutura silábica do português do Brasil. Sobre estes aspectos, o documento destaca a existência de três relações que os estudantes precisam desenvolver para consolidar sua alfabetização: “a) as relações entre a variedade de língua oral falada e a língua escrita (perspectiva sociolinguística); b) os tipos de relações fonoortográficas do português do Brasil; e c) a estrutura da sílaba do português do Brasil (perspectiva fonológica).” (BRASIL, 2017, p. 91).

Com base nessas relações, a BNCC (2017, p. 37) aponta para o aprendizado de

\begin{abstract}
Conhecimentos grafofônicos, ortográficos, lexicais, morfológicos, sintáticos, textuais, discursivos, sociolinguísticos e semióticos que operam nas análises linguísticas e semióticas necessárias à compreensão e à produção de linguagens estarão, concomitantemente, sendo construídos durante o Ensino Fundamental. (...) Conhecer e analisar as relações regulares e irregulares entre fonemas e grafemas na escrita do português do Brasil.
\end{abstract}

Com isso, na BNCC, em alguns momentos, os Método Mistos (conciliação entre métodos Sintéticos e os Analíticos), aparecem ao mesmo em que também apresentam dimensões discursivas destacando aspectos sociolinguísticos e semióticos dos processos de alfabetização.

Por fim, o documento (BRASIL, 2017, p. 93) define as habilidades que devem ser desenvolvidas nos processos de alfabetização (compreendida como capacidade de codificação e decodificação):

- Compreender diferenças entre escrita e outras formas gráficas (outros sistemas de representação);

- Dominar as convenções gráficas (letras maiúsculas e minúsculas, cursiva e script);

- Conhecer o alfabeto; 
- Compreender a natureza alfabética do nosso sistema de escrita;

- Dominar as relações entre grafemas e fonemas;

- Saber decodificar palavras e textos escritos;

- Saber ler, reconhecendo globalmente as palavras;

- Ampliar a sacada do olhar para porções maiores de texto que meras palavras, desenvolvendo assim fluência e rapidez de leitura (fatiamento).

Com isso, percebe-se que a concepção de alfabetização subjacente à BNCC não se alinha ao preconizado pelas teorias construtivista, de Piaget (1970), ou sociointeracionista, de Vygotsky (2010), e nem pelas ideias da Psicogênese da Língua Escrita, de Ferreiro e Teberosky (1985). Tão pouco se aproxima do conceito de letramento ${ }^{8}$ (SOARES, 2016). A não observância de aspectos relacionados às ideias destas correntes de pensamento apontam para um modelo de alfabetização deslocado das condições socioculturais das crianças e das realidades plurais das escolas, formação docente, infraestrutura pedagógica e demais condicionantes estruturais que marcam desigualdades no país (GERALDI, 2015).

Assim, a proposta de alfabetização presente na BNCC evidencia o resgate de uma concepção de alfabetização mecanicista, baseada nos Métodos Sintéticos, em especial o Método Fônico.

Isso demonstra uma ruptura com as concepções de alfabetização abordadas em documentos curriculares anteriores, como os PCNs e as DCNs, que preconizaram perspectivas construtivistas, bem como a importância do uso social da língua escrita e falada na formação do cidadão. Embora a implementação destes documentos não tenha sido obrigatória, eles se configuraram como referências importantes que influenciaram a formulação de currículos locais, a elaboração de materiais didático-pedagógicos (principalmente o livro didático) e, também, os cursos de formação de professores alfabetizadores.

Certamente esta ruptura traz desafios para as redes de ensino e unidades escolares. Se, desde a década de 1990, a organização curricular vinha sendo

\footnotetext{
${ }^{8}$ A ideia de letramento é abordada com mais robustez no capítulo referente à Educação Infantil. O documento também faz referência ao letramento em outras partes do documento. No entanto, no subtópico 4.1.1.1 - foco de nossa análise -, o documento apenas menciona a necessidade de se ampliar o letramento "por meio da progressiva incorporação de estratégias de leitura em textos de nível de complexidade crescente" (BRASIL, 2017, p. 89).
} 
construída com base em orientações de base construtivista e, também, com base no letramento, agora, os profissionais da Educação precisam rever e reconstruir seus currículos a partir de outras bases epistemológicas que colocam as concepções mecanicistas de codificação/decodificação no centro do processo de alfabetização. É este o desafio enfrentado pelo município de Duque de Caxias, que, em 2019, iniciou o processo de reestruturação curricular, ainda em curso.

O próximo capítulo abordará as concepções de alfabetização presente nos documentos curriculares de Duque de Caxias e analisará, também, os documentos elaborados, até o momento da escrita deste trabalho, nos processos de reestruturação curricular em andamento no município. 


\section{A atual reestruturação curricular do município de Duque de Caxias/RJ}

\section{1}

\section{Apresentando o município de Duque de Caxias/RJ}

Ao observar aspectos históricos, organização geopolítica, atividades econômicas e educacionais, observa-se que o município de Duque de Caxias possui importância de destaque no estado do Rio de Janeiro, especialmente pela indústria de refino do petróleo (Refinaria de Petróleo de Duque de Caxias), localizada no $2^{\circ}$ Distrito (Campos Elíseos) do município. Esta refinaria mobiliza a atividade econômica do município e do estado e contribui significativamente para que o município tenha o $2^{\circ}$ maior Produto Interno Bruto (PIB) do estado e o $18^{\circ}$ do país (IBGE, 2017).

Duque de Caxias é um município localizado na região metropolitana do Estado do Rio de Janeiro e é composto por quatro distritos: $1^{\circ}$ Distrito (Duque de Caxias), $2^{\circ}$ Distrito (Campos Elíseos), $3^{\circ}$ Distrito (Imbariê) e $4^{\circ}$ Distrito (Xerém). Dados do IBGE (2017) apontam que Duque de Caxias possui 924.624 habitantes, uma área territorial de $467,319 \mathrm{~km}^{2}$, um Produto Interno Bruto (PIB) de R\$ 45.894,84 e Índice de Desenvolvimento Humano Municipal (IDHM) de 0,711, (IBGE, 2017).

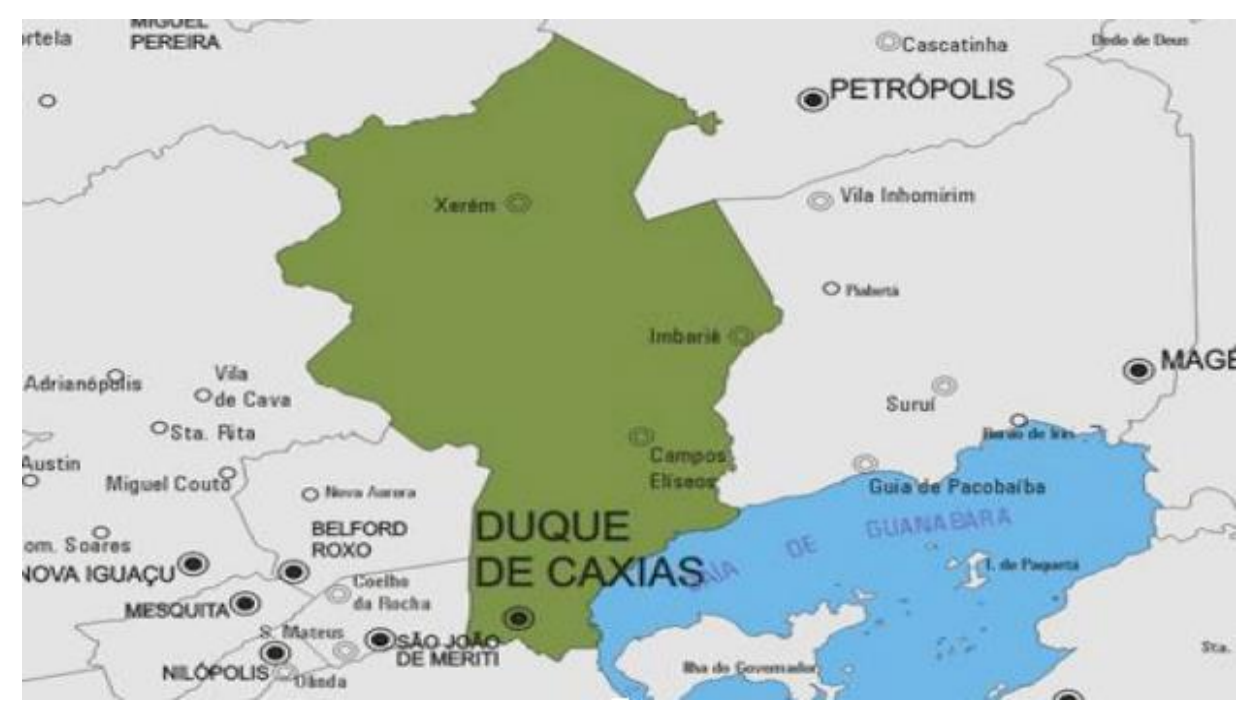

Figura 1: Mapa do Município de Duque de Caxias. Disponível em:

cidades.ibge.gov.br/brasil/rj/duque-de-caxias/panorama. Acesso em 17 nov. 2020. 
Com relação às características educacionais, a rede municipal de ensino de Duque de Caxias $^{9}$ tem, atualmente, 35 creches, 130 escolas de ensino fundamental, com um total de 165 escolas. As matrículas escolares estão divididas da seguinte forma: 2.491 em creches; 8.845 em pré-escolas; 39.997 nos anos iniciais do ensino fundamental; 16.201 nos anos finais e 16.201 matrículas na EJA.

Com relação ao IDEB dos anos iniciais do ensino fundamental, os dados apontam uma tímida progressão do indicador. Pode-se observar pelos dados da Tabela 1 que Duque de Caxias não tem conseguido, desde 2013, alcançar as metas projetas. Em 2019, a meta projetada foi de 5,3 e o município obteve o valor de apenas 4,7, evidenciando a necessidade de melhorar os indicadores de fluxo escolar e de desempenho no SAEB.

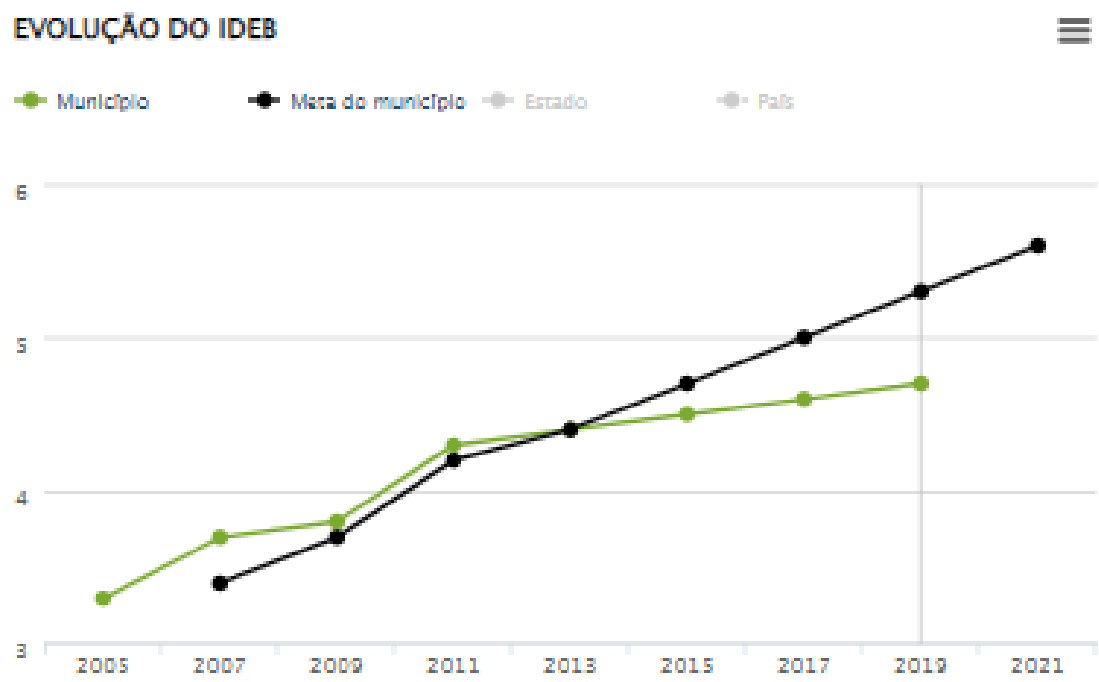

Tabela 1: Resultado do IDEB do Município de Duque de Caxias. Fonte: site Qedu . Acesso em 20. jan. 2021.

Ao que tudo indica, este estudo pode apoiar outras análises sobre os porquês destes resultados, uma vez que eles resultam, em sua maioria, do que se faz na área da alfabetização.

A próxima subseção deste capítulo abordará os documentos curriculares vigentes na rede municipal de ensino de Duque de Caxias e a atual reestruturação curricular e o texto introdutório.

9 Disponível em: https://smeduquedecaxias.rj.gov.br/smeportal/. Acesso em 17 nov. 2020. 


\section{2}

\section{A proposta de reestruturação do currículo da rede municipal de Duque de Caxias}

\subsection{1}

\section{Antecedentes}

Atualmente, a rede municipal de ensino de Duque de Caxias está implementando um processo de reestruturação de seu currículo, elaborado em 2002 e em revisão. Este documento denomina-se Caderno Escola em Movimento e apresenta dois tópicos. O primeiro tópico, denominado Pressupostos TeóricoFilosóficos ${ }^{10}$, apresenta as concepções teóricas que fundamentam o currículo da rede e destaca a importância de se compreender o currículo como um processo em constante movimento (DUQUE DE CAXIAS, 2002, p. 9-10):

A Escola é semelhante a um organismo vivo: dinâmica e em movimento. É parte e espelho da comunidade na qual está mergulhada, revelando o movimento social mais amplo, suas conquistas e contradições. Constitui os que a ela pertencem e por eles é constituída. Assim sendo, a escola expõe o movimento humano e social que a integra. É plural e complexa, constituída na História e construtora de uma história particular. (...) Privilegia-se a concepção sociointeracionista e seus princípios como pilares desta proposta pedagógica sem, no entanto, absolutizá-la e/ou desconsiderar a validade de outras concepções (outros referenciais serão apropriados pelas ações administrativo-pedagógicas sempre que necessário).

O documento, adota a perspectiva sociointeracionista destacando que a aprendizagem se faz nas relações e nas interações sociais, (re)fazendo as culturas, os saberes comunitários, linguísticos, científicos e, ao mesmo tempo, sendo incessantemente constituída pela história dos indivíduos na realidade social. Nessa direção, o documento enfatiza:

$\mathrm{Na}$ visão sociointeracionista, o conhecimento é fruto das interações sociais que se estabelecem pela mediação dos signos culturais constituídos na coletividade. O sujeito é social, criador e recriador de cultura, sendo transformado pelos valores culturais do ambiente, ao mesmo tempo que o transforma (DUQUE DE CAXIAS, 2002, p. 16).

10 Em 2004, foi divulgado um outro documento denominado Proposta Pedagógica da Secretaria de Educação de Duque de Caxias. Trata-se de uma segunda versão do documento Pressupostos Teóricos Filosóficos. Ambos possuem o mesmo objetivo: apresentar as concepções de aprendizagem subjacentes à proposta curricular da rede de ensino de Duque de Caxias. 
Essa concepção se alinha ao pensamento de Freire (2000), pois aborda a necessidade de superação conteudista das propostas didático-curriculares, especialmente na elaboração de uma política curricular conectada às linguagens cotidianas, à formação integral do indivíduo e à transformação das realidades. Tal alinhamento pode ser identificado no documento, quando afirma:

Na perspectiva sociointeracionista a escola é considerada espaço de ampliação das visões de mundo, objetivando a formação do sujeito crítico, construtor de conhecimento na interação com o outro. Não se trata de impor a realidade ou de apresentá-la ao sujeito da aprendizagem, mas de discuti-la, reconstruindo-a e reinventando-a no contexto educativo (DUQUE DE CAXIAS, 2002, p. 20).

Para Freire (2000, p. 123), “(...) a compreensão do currículo abarca a vida mesma da escola, o que nela se faz ou não se faz, as relações entre todos e todas as que fazem a escola", se aproximando, portanto, da perspectiva sociointeracionista.

O conhecimento implica constituição de significados e ampliação de visões de mundo. E dinâmico, processual, sempre em movimento. Implica construções/reconstruções sucessivas da realidade por parte do sujeito. Em cada contexto social, político e histórico, transformam-se as dimensões do conhecimento, à medida que são reconstruídas. Conhecimento é movimento; portanto, é histórico; modifica-se com a intervenção dos sujeitos que o produzem. Neste sentido, aponta-se para a visão social da produção do conhecimento (DUQUE DE CAXIAS, 2002, p. 17).

O segundo tópico, "Propostas Pedagógicas", do Caderno Escola em Movimento, foi publicado em $2004^{11}$, com uma perspectiva inter e transdisciplinar, sintonizada com a ideia de currículo em movimento do tópico anterior, "Pressupostos Teórico-Filosóficos".

É no tópico "Propostas Pedagógicas" que se encontram os conteúdos curriculares a serem desenvolvidos em cada disciplina, mas com a sugestão de que a disciplina não se limite prescritivamente a conteúdos pré-estabelecidos. Com isso, ressalta a importância do pensamento criativo ao defender que a educação se concretiza nos pilares “aprender a ser, aprender a fazer, aprender a viver juntos, aprender a conhecer" (DUQUE DE CAXIAS, 2004, p. 18 apud Morin, 2000, p. 76).

\footnotetext{
${ }^{11}$ Este documento é uma complementação ao documento Pressupostos Teórico Filosóficos.
} 
Para reafirmar o alinhamento à visão sociointeracionista, o tópico "Propostas Pedagógicas" (DUQUE DE CAXIAS, 2004, p. 46) destaca que os principais conteúdos conceituais a serem trabalhados durante a alfabetização podem ser assim organizados:

1. diferenciação entre símbolos alfabéticos e os demais;

2. reconhecimento de funções e características de diferentes gêneros textuais;

3. compreensão do funcionamento do sistema alfabético;

4. compreensão de convenções ortográficas;

5. distinção entre elementos presentes na produção oral em momentos formais ou informais.

É nessa perspectiva e em forma de ciclo que a rede de ensino do município de Duque de Caxias organiza, até hoje, a etapa referente a alfabetização, o que se encontra em consonância com os estudos de Ferreiro e Teberosky (1985). É, também, pautado no currículo elaborado em 2002, que adota uma perspectiva sociointeracionista, que as escolas e professores organizam suas práticas pedagógicas.

Na perspectiva do trabalho em ciclos, as orientações curriculares (DUQUE DE CAXIAS, 2004, p. 46) indicam alguns aspectos a serem abordados na prática pedagógica assentada no sociointeracionismo:

1. Escuta de textos lidos em voz alta;

2. Leitura de diferentes tipos de texto previstos para o Ciclo, combinando a decifração com estratégias antecipatórias;

3. Reflexão sobre o sistema de escrita e a organização da língua;

4. Análise textual, observando características dos textos informativos, narrativos e poéticos;

5. Produção de textos a partir de outros conhecidos (reescritas e decalques);

6. Produção de diferentes tipos de texto, adequados às situações propostas;

7. Revisão textual em parceria, com foco em aspectos discursivos e ortográficos;

8. Utilização do dicionário para resolução de dúvidas sobre a escrita e reconhecimento de diferentes sentidos das palavras;

9. Emissão de opiniões sobre o que leu ou ouviu;

10. Participação em situações mais formais de intercâmbio oral.

É a partir das concepções presentes nestes dois documentos - "Pressupostos 
Teórico-Filosóficos" e "Propostas Pedagógicas" - que se desenvolve o processo de reestruturação curricular da rede de ensino de Duque de Caxias, apresentada na próxima subseção.

\subsection{2}

\section{Atual reestruturação curricular do Município de Duque de Caxias}

Em 2019, a Secretaria Municipal de Educação (SME) de Duque de Caxias organizou a Comissão de Reestruturação Curricular para dar início ao processo de reestruturação curricular da rede. Esta comissão foi composta por professores pesquisadores da Faculdade de Educação da Baixada Fluminense (FEBF/UERJ), por representantes do Conselho Municipal de Educação e do Fórum Municipal de Educação com o objetivo de "organizar e viabilizar um amplo debate em torno do currículo desejado, além de buscar garantir um encaminhamento pautado na participação democrática e transformadora” (DUQUE DE CAXIAS, 2020, p. 10).

A primeira ação concretizada foi a realização, em 6 de junho de 2019, no Colégio Pedro II - Campus Duque de Caxias, do Seminário de Abertura: Proposta Curricular da Rede Municipal de Ensino para a discussão, com professores da FEBF/UERJ dos aspectos epistemológicos e concepções de currículo para subsidiar o processo de reestruturação curricular da rede. Além disso, foi apresentado o conjunto de ações do processo de reestruturação curricular. Essas ações foram organizadas em quatro etapas: Preparação (1); Consulta pública (2); Deliberação (3); e Apropriação (4).

$\mathrm{Na}$ etapa de preparação, que ocorreu ainda em 2019, as ações realizadas foram:

1. Realização do seminário de abertura;

2. Divulgação do calendário de atividades;

3. Organização de grupos de estudo nas unidades escolares para o levantamento das concepções de currículo adotadas em cada uma delas;

4. Publicação do edital para a seleção dos professores redatores; ${ }^{12}$

12 Esses professores foram selecionados a partir de um processo seletivo interno, acumulando a função de professor e de Professor redator, além de participar de oficinas ofertadas pela FEBF/UERJ. 
5. Reunião com profissionais selecionados e organização do trabalho;

6. Sistematização dos dados coletados nos grupos de estudo e organização dos polos regionais.

Após esse Seminário de Abertura, a SME/Duque de Caxias emitiu um ofício para que todas as escolas realizassem Grupos de Estudo (GE) envolvendo os diretores, orientadores educacionais, orientadores pedagógicos e professores, tendo, como temática de apresentação, os aspectos gerais da reestruturação curricular. Assim, no dia 14 de junho ${ }^{13}$ de 2019, um roteiro foi enviado às escolas para que os orientadores educacionais e pedagógicos - mediadores das discussões do grupo de estudos - iniciassem as atividades em suas respectivas unidades escolares. Esse roteiro foi elaborado pela SME e os profissionais que integram o grupo da base de reestruturação curricular.

Como professora alfabetizadora da rede de ensino de Duque de Caxias, participei do grupo de estudo realizado na escola em que atuava na época $(2019)^{14}$. Nas discussões realizadas, foram apresentadas as metas e as estratégias do Plano Municipal de Educação (PME) de Duque de Caxias e algumas questões fundamentais para o processo de composição do currículo. Foi apresentado, também, um questionário com oito perguntas sobre os aspectos curriculares. Esse questionário foi construído por professoras da FEBF/UERJ e por integrantes do SME, cujo objetivo foi levantar informações sobre "as concepções de currículo que permeiam a prática pedagógica dos profissionais da rede" (DUQUE DE CAXIAS, 2020, p. 11).

Os professores, junto aos orientadores educacionais e pedagógicos, responderam às seguintes questões:

1. Que concepção de sociedade, de homem, de escola, de desenvolvimento e de aprendizagem está presente no contexto escolar atual?

2. Que escola queremos?

3. O que estamos ensinando e para quê?

\footnotetext{
${ }^{13}$ Neste mês também foi realizado o processo de seleção dos professores redatores que se juntaram à Comissão para a organização do documento.

${ }^{14}$ Durante esse período fui realocada em outra escola, pois a escola que atuava foi fechada para obras.
} 
4. Como ocorrem as definições curriculares na escola?

5. Que alunos estamos formando?

6. O ensino escolar no atual contexto contribui de forma significativa para a emancipação humana?

7. Qual proposta pedagógica contribui para a concretização da sociedade que queremos?

8. Qual é a função da escola pública?

Por meio deste questionário, a SME/Duque de Caxias fez um diagnóstico para conhecer as concepções de currículo, aprendizagem e as propostas pedagógicas dos professores de cada unidade escolar. Houve a consideração de que essas questões eram relevantes para o desenvolvimento da reestruturação curricular, pois possibilitava aos professores a discussão e a reflexão acerca de concepções de currículo, de aprendizagem, de formação docente, dentre outros aspectos. Além disso, tais discussões atendiam à proposta de construção coletiva do novo currículo.

Após esta etapa, foi realizado, em fevereiro de 2020, o II Seminário de Concepções de Currículo, com o tema: "Política e Concepções Curriculares", que contou com a participação da professora Malvina Tuttman (Presidente do Conselho Estadual de Educação) e do professor Marcelo Mocarzel (integrante do Conselho Estadual de Educação). Ainda em fevereiro, a SME/Duque de Caxias organizou grupos de trabalho (GTs) por componente curricular para viabilizar a participação de todos os professores da rede de ensino. Isso porque, como veremos mais adiante, deu-se ênfase e prioridade à forma coletiva de reformular o currículo da rede. Os GTs tinham o objetivo principal de diagnosticar os interesses dos professores e foram adaptados para o modelo remoto, em formato de lives devido à pandemia provocada pelo vírus da COVID-19 15 . A pandemia exigiu, entre outras medidas, o distanciamento social, fazendo com que as atividades previstas para ocorrerem de forma presencial fossem adaptadas para a modalidade on-line, sendo realizadas reuniões com membros internos e externos, estudos e debates entre os professores redatores e Comissão, palestras/lives com autores convidados para aprofundar a discussão sobre currículo, entre outras atividades (DUQUE DE CAXIAS, 2020).

\footnotetext{
${ }^{15}$ Em abril de 2020, houve a substituição da assessoria da FEBF/UERJ pela assessoria da UFRRJ. Os motivos que justificam o afastamento da FEBF deste processo foram explicitados em carta enviada à Comissão e aos professores redatores.
} 
Apesar disso, a participação dos profissionais da rede de ensino nestas atividades ficou bastante comprometida em função das várias dificuldades presentes no acesso remoto, dificultando, assim, a proposta de (re)construção coletiva do currículo.

Como forma de tentar diminuir as distâncias provocadas pelo isolamento social, a SME/Duque de Caxias, junto com os professores redatores promoveram reuniões com as equipes pedagógicas das escolas e elaboraram materiais que foram divulgados na página on-line da SME com o intuito de "proporcionar, ainda que de modo modesto, o acesso público ao documento em construção" (DUQUE DE CAXIAS, 2020, p. 13).

Assim, de maneira remota, as atividades da reestruturação curricular foram continuadas. A fim de compreender mais e melhor o debate sobre as concepções de currículo e de alfabetização realizado nas atividades do processo de reestruturação, optamos por analisar o documento já apresentado - Reestruturação curricular: texto introdutório - e as palestras/lives que foram realizadas com especialistas do campo da educação, em especial, do campo do currículo.

\subsection{3}

\section{Reestruturação curricular: texto introdutório}

Como já mencionado na subseção anterior, uma das ações do processo de reestruturação curricular foi a constituição de Grupos de Estudo (GE), nos quais os professores da rede de ensino de Duque de Caxias responderam a algumas perguntas que subsidiaram a construção do documento preliminar, sistematizado e organizado pelos professores redatores que participaram de encontros de formação e de estudo sob a coordenação da Professora Teresa Cavalcanti (Vice-Diretora da FEBF e integrante da Comissão Organizadora).

Além de considerar os debates promovidos nos GEs das unidades escolares, o texto elaborado também se fundamentou nos dois tópicos do documento curricular Caderno Escola em Movimento - os Pressupostos Teórico-Filosóficos publicados em 2002 e na Proposta Pedagógica de 2004. Observou-se que o documento faz a menção à BNCC como impulsionadora do processo de reestruturação, mas não há menção às concepções, diretrizes, orientações nela contidas. 
Uma vez que políticas educacionais como a BNCC e o PME, por exemplo, despontam a necessidade de uma reformulação curricular, optou-se neste caso por realizar o processo com o envolvimento direto de seus profissionais. Para isso, a produção deste texto curricular está sendo desenvolvida por diversos professores da Rede Municipal de Duque de Caxias, que estão embasando o documento a partir dos saberes do campo da prática em diálogo com todos os profissionais desta Rede (DUQUE DE CAXIAS, 2020, p. 6).

Embora impulsionadora do processo de reestruturação curricular, a BNCC é vista com certa resistência no documento, que reafirma a autonomia das redes de ensino em (re)formular seus próprios currículos.

Reafirma-se, aqui, a autonomia das formulações da rede em relação à Base Nacional Comum Curricular (BNCC), que, embora seja um documento normativo elaborado no âmbito federal que pretende orientar a aprendizagem em todas as redes de ensino do Brasil e em suas instituições públicas e privadas, não deve ser, para o trabalho em voga, uma referência absoluta a ser reproduzida acriticamente (DUQUE DE CAXIAS, 2020, p. 5).

Assim, a rede de ensino do município de Duque de Caxias se viu desafiada a reformular seu currículo pela enorme defasagem no tempo (mais de 18 anos sem reformulações curriculares) e, também, pelos documentos normativos, em especial a BNCC e o PME da rede, mas resguardando a sua autonomia na construção de sua própria política curricular.

O documento destaca que a reestruturação curricular deve se assentar em cinco pontos, a saber:

I. o trabalho realizado pelos Professores (a experiência docente, que se desdobra em um saber docente) nas escolas, porque é no chão da escola que o currículo se estabelece; II. o contexto social, cultural e ambiental dos educandos, que determina as situações de aprendizagem envolvidas na prática pedagógica; III. o Projeto Político-Pedagógico (PPP) das Escolas, porque é um documento que, além de ser elaborado por todos os agentes ativos e participativos da unidade escolar, é construído com base na realidade da comunidade escolar que ele visa atender e constitui o instrumento que define a identidade da Escola e indica os caminhos para se ensinar com qualidade, numa proposta atualizada e contextualizada com a realidade de seus educandos; IV. o Plano Municipal de Educação de Duque de Caxias (PME), cuja elaboração foi concluída em junho de 
2015, após amplo debate envolvendo diversos setores da sociedade civil organizada e membros dos governos Municipal e Estadual1 ; V. a Orientação da Rede, levando em consideração a autonomia no fazer pedagógico das unidades escolares, obrigatoriamente circunscrita a uma política pública executada por uma Secretaria de Governo, que assegura a legalidade do ensino adotado nas suas escolas e legitima a prática docente exercida pelo seu professorado em toda a Rede que regula (DUQUE DE CAXIAS, 2020, p.4-5).

Embora cite o PME, não há menção à $\mathrm{BNCC}$ em nenhum desses cinco pontos, o que nos leva a crer que a BNCC foi um documento impulsionador para a implementação do processo de reestruturação curricular, mas não parece ser um documento referência neste processo. Isso fica mais claro na seguinte passagem do documento:

Sob o pretexto de melhorar os resultados da educação nacional, a BNCC foi proposta, assim, como uma política de Estado cuja finalidade seria concretizar alguns objetivos que já se faziam presentes na legislação brasileira. $\mathrm{O}$ processo de resistência à $\mathrm{BNCC}$ - iniciado pelos que discordam da existência de um currículo unificado para o país, da forma de sua elaboração, do seu processo de implementação e da sua ênfase nas "competências" - também trouxe ao debate a influência das agências internacionais e dos objetivos das avaliações de larga escala. Além disso, devido à extensão continental do país e à diversidade de experiências e matrizes culturais presentes na formação do povo brasileiro, sempre foi muito difícil a implementação de um currículo escolar nacional único (DUQUE DE CAXIAS, 2020, p. 7).

Esses excertos são fortes indícios de uma possível resistência da rede de ensino às concepções de aprendizagem contidas na BNCC, o que coloca em dúvida a efetividade da política curricular nacional, uma vez que Duque de Caxias vem apontando, pelo menos no documento introdutório do processo de reestruturação curricular, certa resistência à adesão ao currículo nacional.

Essa resistência também é percebida nas entrelinhas, quando o documento enfatiza a necessidade de se preservar a autonomia das redes de ensino. Respaldado pelo artigo $3^{\circ}$ da LDB, o documento destaca que a garantia da pluralidade de ideias e concepções pedagógicas só será possível se a autonomia dos profissionais da educação (docentes e gestores escolares) estiver plenamente asseverada. Além disso, aponta que a autonomia também se faz presente no documento curricular do estado do Rio de Janeiro e enfatiza que o currículo escolar não deve ser reduzido a prescrições oriundas de outras esferas governamentais. 
Essa autonomia está em consonância com a Deliberação CEE 373 , de 8 de outubro de 2019 , que reconhece a política curricular como orientadora das práticas, nunca sendo usada para censurar, limitar, perseguir e responsabilizar docentes e gestores escolares. Além disso, essa deliberação também destaca a premissa de que as escolas já possuem currículo e que ele é vivo, construído no cotidiano, e não se reduz a documentos e prescrições vindos de nenhuma outra esfera (DUQUE DE CAXIAS, 2020, p. 9).

Cabe ressaltar que o processo de reestruturação curricular ainda está em curso, que outras ações e discussões estão sendo realizadas e que outros documentos serão produzidos. Apesar disso, este documento introdutório oferece fortes indícios que nos levam a crer que o novo currículo da rede de ensino de Duque de Caxias não se fundamentará nas concepções de aprendizagem e de alfabe tização constantes na BNCC.

A hipótese que levantamos sobre essa resistência se fortalece na medida em que o documento ressalta a necessidade de se reformular o currículo de maneira coletiva, dando destaque à participação dos professores.

O propósito de construir coletivamente esse documento ligase ao fato de que, os professores redatores e a Comissão de Reestruturação Curricular estão convictos de que o processo de reestruturação curricular em curso reflete o esforço de construir, na Rede Municipal de Duque de Caxias, um currículo que seja autonomamente elaborado pelo conjunto de educadores que nela atuam e trabalham. Por isso, essa construção sustenta-se na prospecção da pluralidade de práticas já existentes nos espaços escolares e na reflexão coletiva sobre as mudanças necessárias (DUQUE DE CAXIAS, 2020, p. 8).

Reitera-se que o trabalho aqui realizado só logrará êxito se for encarado e reconhecido como fruto do esforço e da participação coletiva, não só dos professores redatores e demais membros da Comissão de Reestruturação Curricular, mas também de todos os profissionais da Educação do Município de Duque de Caxias, que se dedicam à elaboração de um documento que subsidie e chancele a realização de boas práticas pedagógicas que efetivamente contribuam para a formação integral dos nossos educandos (DUQUE DE CAXIAS, 2020, p. 10).

Essa resistência também se verifica na concepção de criança adotada na 
discussão curricular proposta no documento. Baseado em importantes referências da Psicologia do Desenvolvimento (PIAGET, 2010; VYGOTSKY, 2010; WALLON, 2008), da Sociologia da Infância (JAMES, 2004; JENKS, 2010; PROUT, 2010) e, também, da própria legislação brasileira como o Referencial Curricular Nacional para a Educação Infantil (1998) e o Estatuto da Criança e do Adolescente (1990), o documento apresenta a concepção de criança que fundamenta a reestruturação curricular.

\begin{abstract}
Portanto, o presente documento curricular de Duque de Caxias compreende a infância como categoria e construção social e considera a criança como pertencente a um contexto cultural específico, valorizando suas capacidades e suas formas de ver e pensar sobre o mundo que a cerca. Dessa forma, ela é aquela que interage, que pensa, que cria hipótese, que produz e reproduz cultura, sendo protagonista na construção do próprio conhecimento e também sujeito de direitos (DUQUE DE CAXIAS, 2020, p. 16).
\end{abstract}

Considerando que as crianças que frequentam as escolas da rede pública de Duque de Caxias pertencem a diferentes classes sociais, etnia, cor, gêneros, o que leva cada um a possuir diferentes formas de aprender, a escola é compreendida como um espaço de trocas e de encontros e, também, de conflitos, de diálogos e de negociação (CANDAU, 2009). Neste sentido, o currículo deve contemplar essa diversidade, valorizando as diferentes formas de ser e de estar no mundo, se constituindo, assim, como um ambiente justo, inclusivo e democrático (DUQUE DE CAXIAS, 2020).

Essa perspectiva apontada no documento introdutório não parece se alinhar à perspectiva da BNCC que, embora aponte para o reconhecimento da existência de diferentes infâncias e mencione o educar e o cuidar como indissociáveis do processo educativo, não contempla os aspectos culturais e sociais que permeiam o cotidiano escolar e que, portanto, devem ser levados em conta no currículo da escola e da rede de ensino.

Depois de apresentar a concepção de criança que norteia a reestruturação curricular de Duque de Caxias, o documento discute as concepções de aprendizagem e de currículo a partir das respostas que os professores deram ao questionário que lhes foi apresentado nos Grupos de Estudo. A compilação dessas respostas apontou, por exemplo, a necessidade de se compreender mais e melhor os 
conhecimentos produzidos na escola como um elemento imprescindível para a reflexão sobre currículo.

O conhecimento escolar, compreendido aqui como conhecimento produzido e não só assimilado pelos sujeitos escolares, tem como fundamento uma articulação e uma relação de crítica e diálogo entre os conhecimentos selecionados e legitimados socialmente (os conteúdos científicos formais a serem ensinados), as demandas sociais e locais e as tradições culturais nas quais os sujeitos da escola se inserem. Esse conjunto de saberes passa, na escola, por um processo de descontextualização e recontextualização. Portanto, o que distingue os conhecimentos ou saberes escolares desse conjunto de outras formas de conhecimento produzidos em diferentes espaços sociais é a articulação específica produzida nos espaços escolares entre esses saberes de referência (DUQUE DE CAXIAS, 2020, p. 22).

Sobre este aspecto, o documento destaca que o entendimento dos professores sobre o espaço escolar como um lócus de produção de conhecimento conduz a uma visão de que a escola é capaz de superar seu próprio papel reprodutivista e viabilizar aprendizagens significativas aos educandos. Assim, o debate sobre o que ensinar, deve vir acompanhado de um debate mais amplo, sobre por que determinados saberes são considerados conhecimentos e outros não e porque alguns conhecimentos são ensinados e outros não. Essa discussão foi destacada como imprescindível para o debate sobre currículo.

Além deste aspecto, os professores destacaram que a concepção de aprendizagem baseada no sociointeracionismo prevalece nas práticas pedagógicas das escolas, mas que não há uma adesão unânime a esta concepção, sobretudo porque a estrutura escolar não favorece a efetivação de uma proposta educacional sociointeracionista. De fato, como mencionado anteriormente, os dois tópicos que compõem o documento curricular Cadernos Escola em Movimento destacam a perspectiva sociointeracionista do currículo até então em vigência na rede de ensino de Duque de Caxias.

Mencionada nos Pressupostos Teóricos da Proposta Curricular da Rede Municipal de Duque de Caxias desde 2002, a concepção sociointeracionista afirma que a aprendizagem ocorre através das relações por meio das quais os sujeitos trocam ideias, leituras e experiências que culminarão na produção de conhecimentos. Em sua modulação sócio-histórica, tendo o materialismo histórico- 
dialético como base, autores como Vygotsky (2007, 2010), Bakhtin (1997) e Luria (2010) refletem sobre a dimensão social do desenvolvimento humano e suas interações sociais (DUQUE DE CAXIAS, 2020, p. 23).

O documento destaca, então, que a realidade engessada das escolas dificulta a efetivação de um trabalho pedagógico assentado em concepções sociointeracionistas:

A organização dos tempos e espaços escolares, assim como a realidade dos professores que trabalham em várias escolas $\mathrm{e}$ turmas e ausência de tempo maior de planejamento garantido e reunião entre os pares não permitem a efetivação dessa vertente teórica que defende o desenvolvimento das pessoas como seres humanos, com base nas interações sociais, ou seja, com outro sujeito social, tendo como mediação o conhecimento, na relação com os sistemas simbólicos da cultura na qual se está inserido. A dificuldade na efetivação de uma metodologia fundada nos princípios sociointeracionistas, por motivos já mencionados, limita o trabalho com a cultura e a mediação, uma vez que conceitos como a relação da linguagem e do pensamento se desenvolvem por meio da interação com o outro (DUQUE DE CAXIAS, 2020, p. 24).

Também foi percebido, pela compilação das respostas dos professores ao questionário, a presença de concepções relacionadas às teorias críticas e pós-críticas de currículo.

A aproximação às teorias críticas (protagonizadas, no Brasil, por autores como Paulo Freire, Dermeval Saviani e José Carlos Libâneo) é percebida quando os professores apontam a escola como reprodutora do pensamento da classe dominante, da lógica mercadológica que adentra a escola e da força que o conceito de meritocracia tem no contexto escolar. Essas temáticas encontram

eco nas Teorias Críticas de currículo, uma vez que a escola seria uma ferramenta de legitimação das desigualdades sociais e do currículo, atrelado aos interesses da classe dominante e, portanto, do capital. Em outras palavras, a escola serviria como aparato de controle social, com a função de reproduzir cultural e socialmente a hegemonia de determinados grupos da sociedade. Pode-se aprofundar tais questões por meio das Teorias CríticoReprodutivas de currículo, que apontam para o papel da escola como reprodutora, mas sem muita perspectiva de superação desse quadro (DUQUE DE CAXIAS, 2020, p. 25).

Ao mesmo tempo, os professores também apontaram aspectos, como o conceito de diversidade cultural, que se aproximam das diferentes tendências (Pós 
Estruturais, Pós-Coloniais, Pós-Modernas, Pós-Fundacionais e Pós-Marxistas) das teorias pós-críticas (LOPES, 2013).

Essa ênfase na diversidade e o destaque às identidades múltiplas em diálogo nos contextos de aprendizagem sugere uma aproximação entre parte das convicções presentes na Rede de Duque de Caxias e as concepções educacionais atualmente designadas como "Pós-Críticas". Estas incluem temáticas e categorias destinadas à compreensão das relações entre poder e identidades sociais e entre a escola e a sociedade contemporânea tomada como espaço multicultural (DUQUE DE CAXIAS, 2020, p. 28-29).

De um modo geral, as abordagens pós-críticas entendem que não é mais permitido à escola a adoção de práticas pedagógicas uniformizantes, por mais bem intencionadas e planejadas que sejam. A escola contemporânea é desafiada a ressignificar a prática pedagógica incorporando o cruzamento de distintas fontes de produção do saber. Isso porque com "a aprendizagem dos mesmos conhecimentos por todos os estudantes, conformando-os aos estágios universais de desenvolvimento, corre-se o risco de promover a exclusão das diferenças" (DUQUE DE CAXIAS, 2020, p. 30).

Nesse sentido, o documento indica que o trabalho nas escolas é desenvolvido com influências de perspectivas críticas e pós-críticas de currículo, uma vez que os professores, na resposta aos questionários, destacaram temas como diversidade, busca de identidades, histórias, memórias e existências (DUQUE DE CAXIAS, 2020, p. 33). Assim, a partir da compilação das respostas dos professores ao questionário, percebe-se que a concepção de escola, de aprendizagem e de currículo se assenta no sociointeracionismo e, também, nas teorias críticas e pós-críticas e aponta para a tentativa de se construir uma proposta pedagógica e de currículo alinhada às vertentes teóricas da interculturalidade ${ }^{16}$, a fim de se construir uma escola plural. Isso evidencia que a (re)construção do currículo do município de Duque de Caxias se distancia das concepções presentes na BNCC (que, como já mencionado, traz em seu bojo a ideia de desenvolvimento de competências e habilidades), reforçando a nossa hipótese de que o processo de reestruturação do

\footnotetext{
16 Baseado em Candau (2008; 2010), o documento adota o termo interculturalidade para fins didáticos, mas destaca a polissemia dos termos inter, multi, pluriculturalidade. Essa expressão - interculturalidade - assume diversas interpretações. A despeito disso, o uso do termo é adequado para a construção de uma agenda educacional multicultural para se pensar a escola, o trabalho docente e o currículo.
} 
currículo da rede de ensino de Duque de Caxias não se inspira no documento curricular nacional. 


\section{O que pensam os professores alfabetizadores sobre a reestruturação curricular?}

Conforme já anunciado, um dos objetivos deste estudo é compreender as concepções de alfabetização dos professores alfabetizadores da rede municipal de educação de Duque de Caxias/RJ. Este capítulo se destina a analisar a fala de alguns profissionais da rede de ensino, a fim de coletar informações sobre suas percepções de currículo e de alfabetização e verificar se essas concepções se afastam ou se distanciam das concepções presentes nos documentos curriculares municipais e nacional.

Em função da pandemia do Coronavírus (COVID-19), medidas de distanciamento social foram adotadas no Brasil. O Decreto $n^{\circ} 46.970$ de 13 de março de 2020 estabeleceu a suspensão das atividades em escolas e universidades, sem previsão de retorno presencial às atividades. Por isso, as entrevistas foram realizadas na modalidade on-line, pela plataforma Google Meet, no período de dezembro de 2020 e janeiro de 2021.

As entrevistas foram guiadas por roteiro semiestruturado previamente elaborado e em função de três eixos principais:

Eixo 1) Motivações que levaram a SME Duque Caxias/RJ à reestruturação do currículo da rede de ensino;

Eixo 2) Concepções de alfabetização dos professores da rede municipal de educação;

Eixo 3) Conhecimento dos professores sobre as concepções de alfabetização presentes nos documentos curriculares da rede de ensino e na BNCC.

A seleção dos entrevistados se deu a partir de uma técnica metodológica denominada bola de neve, que consiste na seleção de participantes a partir das indicações dos próprios entrevistados. Esta técnica de amostragem não probabilística é utilizada em casos em que o pesquisador tem dificuldade em acessar os sujeitos da pesquisa e quando não é necessário haver precisão sobre a quantidade de sujeitos participantes. Por esses motivos, essa técnica se mostrou adequada para o presente estudo, não só porque enfrentamos dificuldades para a realização das entrevistas em função das medidas de distanciamento social, mas também porque a 
natureza qualitativa do estudo não exigiu que a seleção dos participantes se desse por meio de amostras probabilísticas.

Com o intuito de fazer uma breve apresentação dos sujeitos participantes da pesquisa, sintetizamos algumas informações dos entrevistados, como idade, função que desenvolve na rede de ensino, formação e tempo de atuação na rede, conforme constam no Quadro 1.

\begin{tabular}{|c|c|c|c|c|c|}
\hline & Pseudônimo & Idade & Função & Formação & $\begin{array}{c}\text { Tempo de } \\
\text { Magistério } \\
\text { na rede }\end{array}$ \\
\hline 1 & $\begin{array}{l}\text { Alzira } \\
\text { Rufino }\end{array}$ & 47 & Professora & $\begin{array}{c}\text { Graduação em } \\
\text { História e Pós - } \\
\text { Graduação em } \\
\text { História do Rio de } \\
\text { Janeiro e Cultura } \\
\text { Africana }\end{array}$ & 17 \\
\hline 2 & $\begin{array}{c}\text { Abdias } \\
\text { Nascimento }\end{array}$ & 38 & $\begin{array}{l}\text { Orientador } \\
\text { pedagógico }\end{array}$ & $\begin{array}{l}\text { Graduação em } \\
\text { Pedagogia e } \\
\text { Mestrado em } \\
\text { Educação }\end{array}$ & 17 \\
\hline 3 & $\begin{array}{l}\text { Ferreira } \\
\text { Gullar }\end{array}$ & 43 & Professor & $\begin{array}{c}\text { Graduação em } \\
\text { Pedagogia, } \\
\text { Mestrado e } \\
\text { Doutorado em } \\
\text { Educação }\end{array}$ & 13 \\
\hline 4 & $\begin{array}{l}\text { Clarice } \\
\text { Lispector }\end{array}$ & 47 & $\begin{array}{c}\text { Professora } \\
\text { de sala de } \\
\text { leitura }\end{array}$ & $\begin{array}{c}\text { Graduação em } \\
\text { Pedagogia, } \\
\text { Especialização em } \\
\text { Psicopedagogia } \\
\text { Clínica e } \\
\text { Institucional e } \\
\text { Mestrado } \\
\text { Profissional em } \\
\text { Educação } \\
\end{array}$ & 27 \\
\hline 5 & $\begin{array}{c}\text { Cora } \\
\text { Coralina }\end{array}$ & 49 & $\begin{array}{l}\text { Orientadora } \\
\text { pedagógica }\end{array}$ & $\begin{array}{c}\text { Graduação em } \\
\text { Pedagogia, } \\
\text { Especialização } \\
\text { Supervisão } \\
\text { Educacional e } \\
\text { Educação Infantil, } \\
\text { Mestrado } \\
\text { Profissional em } \\
\text { Diversidade e } \\
\text { Inclusão }\end{array}$ & 4 \\
\hline
\end{tabular}


Para melhor apresentação dos resultados da pesquisa, dividimos esse capítulo em três subseções que, em cada uma delas, serão apresentadas e discutidas as temáticas de cada eixo.

\section{1}

\section{Eixo 1) Motivações que levaram a SME Duque Caxias/RJ à reestruturação do currículo da rede de ensino}

Esse eixo se colocou para a pesquisa devido à falta de clareza das motivações que levaram a SME/Duque de Caxias a iniciar o processo de reestruturação de seu currículo. Uma das perguntas da pesquisa foi averiguar se a homologação da BNCC foi motivadora desta reestruturação. De fato, como já observamos no capítulo anterior, a necessidade de implementação da $\mathrm{BNCC}$ foi um dos aspectos que motivou o processo de reestruturação curricular da rede, embora o documento Reestruturação curricular: texto introdutório tenha deixado claro que não se fundamentará nas concepções, perspectivas e diretrizes contidas no documento nacional.

Para a orientadora pedagógica Cora Coralina e, principalmente, para o professor Ferreira Gullar, a BNCC se apresenta como uma motivadora do processo de reestruturação curricular em curso na rede de ensino de Duque de Caxias.

Eu acho que é o interesse de adequar o currículo de Duque de Caxias à BNCC, à Base Curricular, acho que esse é o principal interesse de fazer essa mudança no currículo. (Professor Ferreira Gullar- informação verbal))

$\mathrm{Na}$ verdade, é uma demanda Federal e há uma necessidade, porque, com tempo, a gente precisa dar uma parada como em tudo na vida, dar uma parada, fazer uma autoavaliação, repensar, fazer as modificações necessárias e havia já essa necessidade. (Orientadora Pedagógica Cora Coralina- informação verbal)

Por outro lado, os professores Abdias Nascimento e Clarice Lispector afirmam que a reestruturação curricular foi motivada por "modismos" e pressões 
acadêmicas e sociais.

Eu acho que o que levou foi, mais uma vez, o modismo e uma pressão. As coisas estão mudando e a gente precisa documentar essas mudanças, já que, na prática, a gente não consegue. $\mathrm{O}$ discurso tem que ser esse, a gente tem que acompanhar o discurso da educação. Então, eu acho que tem uma pressão social, uma pressão acadêmica que vai dando conta de dizer "Olha, esse discurso que está aí não vale mais, esse texto que está aí não vale mais, a gente precisa de outro discurso mais moderno, mais atual, mais contemporâneo", só que não corresponde à prática. Eu acho que o trabalho remoto deixou isso muito claro. Porque a falsa autonomia que eles nos deram é sobre eles não terem estruturado um trabalho remoto para nos auxiliar. Então, é "toma, faz do jeito que vocês quiserem", e a gente tem que, em plena pandemia, dar nota para aluno. A gente tem que dar nota para aluno que não teve aula. Então, é muito triste perceber isso, que no discurso é uma coisa, mas que na prática é outra. (Orientador Pedagógico Abdias Nascimento - informação verbal)

Eu vejo o governo de vaidade, com uma secretária toupeira, que precisa deixar marcas, porque isso é o movimento de outras Redes, então, eu acho que Caxias quis acompanhar. (Professora da Sala de Leitura Clarice Lispector-informação verbal)

E, por fim, para a professora Alzira Rufino, a reestruturação curricular foi motivada pelos resultados educacionais que, na percepção dela, não devem estar sendo satisfatórios.

$\mathrm{Eu}$ acho que é até por conta dos resultados, os resultados não devem estar sendo satisfatórios ou sendo alcançados do jeito que a SME gostaria, e aí abriu-se para a gente participar, com opiniões, do que deve ser feito, de como fazer, do por que estar fazendo, porque a gente conhece a nossa realidade, a gente 'tá ali dia a dia, então alguém melhor que nós para saber o que fazer, como fazer e quando fazer? Acho que realmente a gente precisa participar dessa reestruturação. (Professora Alzira Rufino- informação verbal)

Por esses relatos, percebe-se que apenas dois profissionais da rede entendem 
a BNCC, ou, nas palavras da orientadora pedagógica Cora Coralina, a "demanada federal", como a propulsora da revisão curricular da rede. Neste sentido, parece não haver clareza, para pelo menos três entrevistados (Alzira Rufino, Clarice Lisector e Abdias Nacimento) sobre o motivo que levou a rede de Duque de Caxias a implementar este processo de reestruturação curricular. Isso porque o "modismo", a "pressão social e acadêmica" e os "resultados insatisfatórios" não são aspectos mencionados no documento Reestruturação curricular: texto introdutório. Considerando que este documento foi construído coletivamente, a partir de grupos de trabalho e de seminários, nossa hipótese era de que os profissionais da rede de ensino tinham conhecimento sobre os motivos que levaram a rede de ensino a implementar este processo de reestruturação. No entanto, isto não se verificou em todas as entrevistas realizadas, sendo que apenas dois profissionais parecem ter clareza da influência da BNCC ou da "demanda federal ", na revisão curricular.

Um aspecto que chamou a atenção foi a participação desses profissionais nas atividades dos processos de reestruturação do currículo. De acordo com as falas, a pandemia e as atividades, na modalidade on-line, pareceram dificultar e até inviabilizar uma participação efetiva dos profissionais neste processo, como apontam os relatos da professora Alzira Rufino e do professor Ferreira Gullar.

Então, na escola nós tivemos algumas reuniões este ano, na verdade foram duas, tratando do assunto. Sendo que elas foram feitas bem inicialmente, aqui mesmo pelo Google Meet, e aí fica aquela coisa de cair e voltar, então eu não tive como acompanhar a reunião do início ao fim. (Professora Alzira Rufino-informação verbal)

Então, eu até tive interesse quando surgiu a possibilidade e eles lançaram para quem quisesse se inscrever. Mas aí, por uma série de razões, acabou que eu não (...) O ano passado foi um ano complicado, eu acabei não assumindo isso e eu não participo, a não ser pela escola, entendeu? Minha única oportunidade de discutir essa questão foi no GEs esse ano. Eu acho que, esse ano foi muito complicado, eu acho até que poderia deixar para o ano que vem para fazer essa reestruturação num contexto melhor, porque o que me pareceu é que ficou muito improvisado. (Professor Ferreira Gullar-informação verbal)

O orientador pedagógico Abdias Nascimento também não participou do 
processo de reestruturação curricular. No entanto, de acordo com o relato dele, sua não participação se deveu mais à decrença na efetividade da política do que pelas dificuldades impostas pela pandemia.

Então, eu participei da primeira reestruturação curricular. Quando eu entrei, estava tendo uma reestruturação curricular, entre 2002 e 2004. Essa nova, eu não participei, teve uma seleção, inclusive, para pagar especialistas em educação, me recusei a participar dessa seleção. Acho que, com a pandemia, esse processo de reestruturação ficou ainda mais capenga. Nesse momento remoto, eu achei ainda mais complicado e desnecessário. Eu acho que não temos clima, acho que não temos meios democráticos. (...) Eu acho que esse processo de reestruturação é uma coisa que eu lamento, porque não vai dar em nada. Vai dar em um documento, mas eu acho que a gente ainda nem conseguiu, da outra reestruturação, na prática, dar conta de uma formação docente que a gente traga práticas libertadoras. Eu não vejo nas escolas onde eu trabalho uma prática docente, um projeto político pedagógico que dê conta de exercer aquelas coisas do documento que a gente lê. (Orientador Pedagógico Abdias Nascimento - informação verbal)

Por outro lado, a professora Clarice Lispector e a orientadora pedagógica Cora Coralina participam das atividades da reestruturação curricular. No entanto, a professora Clarice Lispector parece compartilhar do mesmo sentimento que o professor Abdias Nascimento, uma vez que se afirmou se sentir "desliludida $e$ desencantada com as politicas educacionais de Caxias ". Apesar dessa descrença e das críticas à forma como a reestruturação está sendo implementada, a professora afirmou participar das atividades.

Eu faço, porque eu sou obrigada a fazer. Eu sou, assim, completamente desiludida e desencantada com as políticas educacionais de Caxias, a forma como a educação é conduzida em Caxias nesse governo. Eu estou num grupo de estudos e aí tem que mandar um documento para a secretaria, eu vou lá, respondo às perguntas, o que eu acho que está de acordo, o que não está de acordo, mas eu não tenho o menor interesse em participar de nada, que foi o que aconteceu durante a pandemia, a reestruturação curricular em Caxias continuou. Uma coisa que eu acho errada, na reestruturação curricular, as perguntas são direcionadas para a turma que você está aquele ano, então você só responde sobre educação infantil. E se no ano que vem eu estiver com o primeiro ano? Segundo ano? Terceiro ano? Pelo menos na minha escola aconteceu assim. Nós somos professores da educação infantil ao quinto ano, todo o primeiro segmento. (Professora da Sala de Leitura Clarice Lispector - informação verbal) 
Eu participei indo às reuniões, sendo multiplicadora nos grupos de estudo, no início desse processo, sendo que agora, na pandemia, foi on-line, mas eu percebo no grupo de WhatsApp muitos questionamentos sobre a reestruturação ter continuado. (Orientadora Pedagógica Cora Coralina - informação verbal)

Neste sentido, de acordo com os relatos, a participação dos profissionais da rede de ensino de Caxias parece não ser tão efetiva como havia previsto o documento Reestruturação curricular: texto introdutório. Embora aponte a modalidade on-line como uma limitação para a participação dos profisssionais da rede, o documento não considera as resistências e as críticas que os profissionais fazem ao processo de reestruturação. Embora a modalidade remota tenha sido um limitador para a construção coletiva do documento curricular, percebe-se, pela fala de Abdias Nascimento, que a não participação de alguns profissionais deve-se, também, à descrença de alguns profissionais nas políticas educacionais da rede de ensino. Embora participe das atividades da reestruturação curricular, "porque é obrigada”, Clarice Lispector também manifesta esta descrença.

Assim, de acordo com as falas dos entrevistados, os motivos que levaram a rede de ensino a reestruturar seu currículo não está claro para os profissionais da rede, pois três delas apontaram motivos diferentes daqueles anunciados no documento Reestruturação curricular: texto introdutório: pressões sociais e acadêmicas, resultados insatisfatórios e modismos e demanda federal. Por outro lado, dois profissionais parecem compreender que a política de reestruturação curricular foi motivada pela BNCC.

Ademais, os relatos apontam para uma não participação efetiva de todos os profissionais da rede, em parte pelas limitações da modalide on-line, e em parte pela descrença na efetividade das políticas educacionais da rede de ensino de Duque de Caxias. Em que pese essa descrença, uma profissional afirmou participar da reestruturação por entender que "é obrigada".

Isso nos faz questionar se o processo de reestruturação curricular de Duque de Caxias é efetivamente coletivo e conta com a participação de todos os profissionais da rede, como atesta o documento. 


\section{2}

\section{Eixo 2) Concepções de alfabetização dos professores da rede municipal de educação}

Esse eixo buscou compreender quais as concepções de alfabetização dos profissionais entrevistados. Para tanto, perguntamos para os entrevistadores: "Para você, o que é alfabetização? E o que é letramento?"

A professora Alzira Rufino e a orientadora pedagógica apresentaram a definição desses dois conceitos, fazendo a distinção entre eles. A compreensão das duas entrevistadas sobre alfabetização e letramento é bem semelhante.

O letramento é grande, é o todo, e a alfabetização é uma parte do letramento, digamos assim. O letramento vai muito além da alfabetização. Ele agrega a leitura de vida daquele ser e ele não foi alfabetizado formalmente, mas ele te dar uma leitura da vida, e você pode usar aqueles eventos. (Professora Alzira Rufino informação verbal)

Bom, aprender a ler e escrever é uma técnica, é uma tecnologia, o caderno, o lápis. A alfabetização é um processo em que a criança consegue decodificar os códigos linguísticos. E o letramento, que a gente aprende, é um pouco mais além. Ela saber interpretar, saber fazer a leitura de mundo, ela ir um pouco mais além. (Orientadora Pedagógica Cora Coralina - informação verbal).

A ideia de que o letramento é maior que a alfabetização também é compreendida pelo professor Ferreira Gullar.

Então, esse é um debate bem interessante, porque assim, tem a galera que percebe esses dois conceitos como complementares, como diferentes, ou vão perceber como iguais. Eu entendo que Alfabetização e Letramento, eles são conceitos que se tangenciam, na medida em que ele se encosta, não é propriamente eles se tangenciam, mas eles mergulham, eles extraem um com o outro, mas têm características que são diferentes, que são específicas. O letramento, ele é uma percepção maior dos juízos sociais, no caso da língua portuguesa, do conhecimento de vários aspectos linguísticos da produção da escrita e da leitura da língua. E, a alfabetização, você pode perceber como uma etapa do processo de formação escolar do aluno. O letramento, ele vai por toda a vida escolar do aluno, mas a alfabetização não, ela tem um tempo determinado. Nesse sentido que eu falo que eles se implicam, mas a alfabetização tem um tempo dela, o aluno não pode chegar no nono ano e ainda estar se alfabetizando. (Professor Ferreira Gullar - informação verbal) 
Esses três relatos parecem se alinhar à explicação de Soares (1989, p. 15) sobre a diferença entre alfabetização e letramento, quando a autora aponta que alfabetizar é "decodificar a língua oral em língua escrita", ao passo que o letramento é "muito mais amplo do que a alfabetização", pois se refere aos usos sociais da linguagem e à produção de sentidos. Esse entendimento sobre alfabetização e letramento também se faz presente na percepção do orientador pedagógico Abdias Nascimento.

Neste sentido, Abdias demonstra uma concepção estruturalista ${ }^{17}$ sobre o ensino da língua portuguesa, ou seja, entende a língua como um conjunto de códigos, estático, pois, nesta concepção estruturalista, a língua é apenas decodificação do código linguístico, sem relacioná-lo com a vida social, histórica e cultural. Para Soares (2003, p. 17), codificar e decodificar é parte do aprender a ler e a escrever.

Pensando nessa prática, que segue essa teoria, a Alfabetização, para mim, é esse mecanismo de aprender a codificar e decodificar. Eu vejo muito, eu acho que está muito colado, na história de alfabetização do Brasil e na prática, esse movimento de como esse aluno, que é necessário, ele tem que decodificar e codificar, aprender a ler e escrever.

Complementarmente, Abdias Nascimento apresenta sua compreensão sobre letramento, alinhada à ideia de uso social da linguagem, conforme apontado por Soares (1998).

O Letramento, que deveria ser inerente à Alfabetização, deveria aprender a andar juntinho, deveria ser a mesma coisa, porque é sobre produção de sentidos, não dá para você falar de decodificação e codificação sem produção de sentido, mas a gente conseguiu na história da Alfabetização do Brasil fazer isso, eu não sei como a gente conseguiu fazer isso, a gente conseguiu lançar um "Vovô viu a uva". Então, esse movimento de Letramento foi fundamental para a gente compreender, e eu acho

17 Entende-se por 'concepção estruturalista' de alfabetização os pressupostos teórico-metodológicos que fundamentam-se mais em resultados práticos, imediatos, pedagogicamente falando, nesse caso, a codificação e decodificação de palavras/textos, conforme aponta Piaget (2003) e Teixeira (1998). 
que ele é esse sentido da Alfabetização, esse sentido da linguagem, o sentido social da linguagem, é para que a gente está lendo e para que a gente está escrevendo. Para que a gente está codificando e decodificando? Que sentido isso tem na nossa vida? Que sentido isso tem no nosso cotidiano? Então, Letramento é esse movimento, também essa teoria, no Brasil, serviu para lembrar à educação, aos alfabetizadores, aos sistemas educacionais que "Olha, essa criança tem que aprender para o mundo", coisa que Paulo Freire já havia falado há muito tempo, mas essa criança tem que aprender para o mundo, e eu acho que isso é o Letramento, é a função social da linguagem. Eu não gosto dessa dicotomia, dessa separação, Alfabetização e Letramento, eu acho que Alfabetização deve ser um movimento de Letramento, que anda junto com o Letramento. (Orientador Pedagógico Abdias Nascimento - informação verbal)

A ideia de que a alfabetização e o letramento caminham juntos também é percebida no relato da professora Clarice Lispector.

Eles são bem juntos, o letramento tem uma imersão social, ele tem um papel. Você lê e escreve, você passa pelo processo de leitura e escrita através de um processo também que é social, de cultura, de participar da cultura, o que a alfabetização não trazia, a alfabetização não traz, acho que muito desse objetivo é você aprender a ler e escrever. Quando surgiu o letramento, eu lembro que isso era muito discutido na rede de Caxias, principalmente, porque a gente alfabetizava - eu sou dessa época que você alfabetizava a criança - com textos estanques, com frases tipo "Vovô viu a uva" e não se discutia porque que o vovô viu a uva, eu acho que o letramento traz uma reflexão sim desse processo, que é social. (Professora da Sala de Leitura Clarice Lispector informação verbal)

Assim, esses relatos apontam para o entendimento de que a alfabetização e o letramento são processos inseparáveis, porém, precisam ser analisados separadamente para melhor compreendê-los (SOARES, 2004), conforme foi apresentado e discutido no capítulo 1. Por um lado, a alfabetização é compreendida como uma técnica, como apontou a orientadora pedagógica Cora Coralina, que ensina as crianças a codificar e a decodificar fonemas e grafemas. Por outro lado, o letramento é a produção de sentidos que se faz nos contextos sociais e culturais nos quais a criança está inserida, como apontou o orientador pedagógico Abdias Nascimento.

Todos parecem compreender que alfabetização e letramento são conceitos diferentes, mas que são interdependentes, pois a produção de sentidos se faz por 
meio do aprendizado da codificação e da decodificação de grafemas e fonemas. Essa interdependência fica evidente no relato do orientador pedagógico Abdias Nascimento, quando aponta para a concepção de "alfabetização a partir de práticas de letramento":

$\mathrm{Eu}$ acho que a concepção de alfabetização como prática de Letramento, para mim, é a sacada da coisa. É óbvio que... Como que as práticas de letramento, como que as teorias de letramento foram, como a gente foi se apropriando delas, é uma outra história. Mas como concepção, eu acho que é a concepção que eu acredito, de alfabetização a partir de práticas de letramento. Eu fui formado nessas bases, é óbvio que tem outras coisas, mas eu acho que tem vida longa a perspectiva de prática de Letramento para mim. (Orientador Pedagógico Abdias Nascimento - informação verbal)

A fim de compreender mais e melhor a percepção dos entrevistados sobre as concepções de alfabetização, perguntamos qual a opinião deles sobre o método fônico. A orientadora pedagógica Cora Coralina relatou ser a favor da adoção deste método na alfabetização das crianças, atestando que percebeu a sua "coerência e a eficácia” nas pesquisas e nos estudos que fez.

Eu sou a favor. Na verdade, na graduação, na pós que eu estudei, eu não aprendi. Nas pesquisas, estudando, eu percebo a coerência e a eficácia, não que seja o único, eu penso que o alfabetizador precisa ter o conhecimento de todos os métodos, porque as crianças não são iguais, há uma criança que vai aprender com muita facilidade pelo método silábico, a outra não, então, por isso, o professor precisa conhecer todos os métodos e estar sempre aberto a aprender. (Orientadora Pedagógica Cora Coralina - informação verbal)

O orientador pedagógico Abdias Nascimento também destaca a necessidade de se utilizar o método fônico para ensinar as crianças a "decodificar as palavras e entender que há uma correspondência entre letra e som, sílaba e fonema”.

Olha, eu acho que a gente vai descobrindo as coisas de modo muito irresponsável com o sistema educacional, porque, assim, a gente experimenta as coisas. As coisas não são experimentadas e aí "Vamos fazer isso aqui, vamos fazer uma formação disso", é a moda, "Agora é construtivista", "Agora é não sei o que", a gente vai descobrindo o que não deu certo. E aí, os nossos alunos são cobaias, eu acho isso horrível, porque a gente vai experimentando neles. Eu acho que tem uma dimensão que isso vai acontecer mesmo, mas eu acho que quando não é autoria da 
escola e do professor, é uma coisa que vem de fora, é um experimento irresponsável no sentido de que a gente não sabe o que está fazendo. Mas eu entendo a necessidade de começar a se pensar a partir do método fônico no sentido de que essas crianças têm que decodificar essas palavras e entender que há uma correspondência entre letra e som, sílaba e fonema. Então, ela tem que entender isso. (Orientador Pedagógico Abdias Nascimento - informação verbal)

Já a professora Clarice Lispector afirma que todos os métodos são válidos e que se vale de estratégias tradicionais para alfabetizar as crianças, em especial aquelas que apresentam alguma deficiência.

Como trabalho muito com criança deficiente, assim, o que acontece, eu acho que o letramento é o melhor caminho, mas às vezes o comprometimento de uma criança é tanto que você tem que fazer o "b com a, ba", "b com e, be", "b com i, "bi". Então, eu acho que isso é muito relativo, eu acho que tudo, como eu falei, tudo é válido, todas as concepções, todos os métodos, tudo é válido quando você quer alfabetizar, principalmente, um aluno que apresenta deficiência. (Professora da Sala de Leitura Clarice Lispector informação verbal)

O professor Ferreira Gullar, por sua vez, afirma não acreditar na eficácia do método fônico, mas ressalta que é preciso estar atento às questões da fonética e da fonologia.

Então, eu não acredito no método fônico como método de alfabetização, mas eu acho que prestar atenção nas questões de fonética, de fonologia, eu acho que é importante como processo de alfabetização. (Professor Ferreira Gullar informação verbal)

E complementa:

Ah, então, eu acho que é o sociointeracionismo, essa questão do construtivismo, a compreensão global de partir do texto, de você não fixar tanto nas questões de fonética, mas entender o processo, entender que a criança vai construindo a própria leitura, construindo a compreensão da leitura e da escrita. Eu acho que é isso que funciona e que pauta o trabalho do 
professor na alfabetização, de um modo geral. (Professor Ferreira Gullar - informação verbal)

Assim, embora se tenha toda uma discussão teórica que aponte a insuficiência do método fônico e sua desconexão com as concepções construtivistas e sociointeracionistas, conforme apresentado no capítulo 1 , o que se verifica é que o método fônico ainda é compreendido pelos profissionais da educação como um método válido para ensinar as crianças a aprender a escrever. Parece não haver dúvidas sobre a necessidade de se estabelecer um método para o ensino da escrita, como aponta Soares (2016, p. 45):

(...) aprendizagem da escrita não é um processo natural, como é aquisição da fala: a fala é inata, é instintiva; sendo inata, instintiva, é naturalmente adquirida, bastando para isso que a criança esteja imersa em ambiente em que ouve e fala a língua materna. A escrita, ao contrário, é uma invenção cultural, a construção de uma visualização dos sons da fala, não um instinto. (...) Em decorrência, se a fala não é, nem precisa ser ensinada de forma explícita, consciente - não há necessidade de métodos para orientar a aquisição do falar e do ouvir-, a escrita precisa ser ensinada por meio de métodos que orientem o processo de aprendizagem do ler e do escrever.

A esse respeito, Carvalho (2008, p. 46) destaca que, independentemente do método escolhido, é preciso que ele esteja assentado em bases teóricas e que as técnicas inerentes ao método escolhido precisam ser bem aplicadas.

Para a professora, seja qual for o método escolhido, o conhecimento das suas bases teóricas é condição essencial, importantíssima, mas não suficiente. A boa aplicação técnica de um método exige prática, tempo e atenção para observar as reações das crianças, registrar os resultados, ver o que acontece no dia-a-dia e procurar soluções para os problemas dos alunos que não acompanham.

A adoção de um método é condição necessária, como aponta Carvalho (2008), para a concretização da aprendizagem. No entanto, deve-se pensar, como nos alerta a autora, sobre o alinhamento entre o método escolhido e a concepção 
teórica que fundamenta o método. Isso porque parece haver, pelos relatos dos entrevistados, um desalinhamento entre a teoria e a prática. Por um lado, eles conhecem as concepções teóricas que fundamentam os documentos curriculares da rede de ensino de Duque de Caxias, quais sejam o sociointeracionismo e o construtivismo, mas atestam que nem sempre conseguem alinhar suas práticas pedagógicas a essas concepções teóricas em função da precariedade das condições contextuais, como apontado nos próximos relatos. Por outro lado, os dois orientadores pedagógicos entrevistados apontaram como válida a adoção do método fônico.

Com isso, pode-se perceber que as concepções teóricas que fundamentam o currículo de Duque de Caxias parecem não ser implementadas nas práticas pedagógicas dos profissionais da educação, uma vez que eles apontaram as condições adversas para se adotar tais perspectivas e, complementarmente, atestaram, pelo menos em dois relatos, o uso do método fônico para a alfabetização das crianças. Com isso, a diferença entre o currículo prescrito e o real, ou em movimento, torna-se um objeto a ser analisado, uma vez que, o pensado e o efetivado têm distanciamentos.

No entanto, é preciso destacar que o método fônico não se ancora nem nos pressupostos teóricos do sociointeracionismo e nem do construtivismo, não havendo, portanto, um alinhamento entre estas duas concepções e o método fônico. Mais do que isso, é preciso questionar a eficácia do método fônico para a alfabetização das crianças que, como discutido no capítulo 1, não parece ser o mais adequado, pelo menos do ponto de vista teórico.

Complementarmente, os entrevistados destacaram o construtivismo como uma teoria e não como um método, mas, para o professor Ferreira Gullar, ele acaba “virando uma confusão em si”, pois "o construtivismo é difundido, é praticado sem formação sólida”. Essa confusão também é percebida no relato do orientador pedagógico Abdias Nascimento, quando ele afirma que o "construtivismo não é nem método, é uma corrente teórica, mas as pessoas começaram a chamar de método sócio-construtivista”.

Essa confusão fica ainda mais complexa quando a orientadora pedagógica Cora Coralina entende o construtivismo como uma filosofia que é utilizada como uma "jogada de marketing” das escolas particulares. 
Eu sou da geração, assim, a gente aprendeu na academia a valorizar muito o construtivismo, que não é um método, é uma filosofia, porém, na sala de aula, com a experiência que obtive no chão da escola, primeiro eu acho que o professor precisa estudar, entender muito, eu peguei uma geração de escolas particulares onde o pai perguntava logo, ao matricular o filho "É construtivismo? Então eu não vou matricular meu filho aqui não". Os pais começaram a ter essa visão que, na verdade, virou um marketing, uma jogada de marketing no início, atraía, mas as pessoas não dominavam, queriam fugir do tradicional, mas não sabiam fazer, porque a alfabetização também é uma técnica a ser aprendida, então precisa de constância, precisa de um domínio do profissional. (Orientadora Pedagógica Cora Coralina - informação verbal)

Já para a professora Clarice Lispector, a escola pública tenta ser construtivista, mas ainda precisa caminhar para se chegar lá.

Claro que, assim, a escola pública tem que caminhar muito para ser construtivista, eu já acho que a gente tem que caminhar muito para que a gente tenha isso, se você pegar uma escola construtivista, como uma escola particular como a Olga Mitá, aí você vai ver o que que é construtivismo. A gente tenta ser construtivista, mas... (Professora da Sala de Leitura Clarice Lispector - informação verbal)

A fala dos entrevistados evidencia uma certa confusão sobre o que é o construtivismo. Parece haver uma clareza do que não é o construtivismo - um método - mas não parece haver clareza sobre o que é o construtivismo e em que ele consiste. Apenas para a professora Alzira Rufino, o conceito de construtivismo parece estar definido com clareza.

O construtivismo é a forma mais ampla e eficaz de construção de conhecimento, porque ele considera que aquela criança veio com uma história, que ela também tem alguma coisa para ensinar. Ele não parte do princípio de que só o professor é detentor do conhecimento. Consegue compartilhar conhecimento que ele tem e dar espaço para os alunos também compartilharem aquilo que eles sabem. (Professora Alzira Rufino - informação verbal) 
A fim de aprofundar a discussão, foi perguntado aos entrevistados se eles sabiam quais as concepções de alfabetização fundamentam o currículo da rede de ensino de Duque de Caxias. Todos atestaram que o currículo é fundamentado, pelo menos no discurso oficial, na concepção sociointeracionista, como atesta, categoricamente, a orientadora pedagógica Cora Coralina.

Em Caxias, a concepção é o sociointeracionismo, é com base em Vygotsky, com base em autores progressistas. (Orientadora Pedagógica Cora Coralina - informação verbal)

Apesar disso, três relatos apontaram que o que ocorre na prática não é bem o que apregoa os documentos oficiais. Isso porque as condições contextuais de atuação dos professores são adversas, fazendo com que eles precisem adotar outras estratégias de ensino que não se alinham às concepções adotadas nos documentos curriculares para conseguir “alcançar o aluno”, como apontou a professora Alzira Rufino.

É o sociointeracionismo, mas, na prática mesmo, a gente tem que tentar de tudo que for alcançar aquele aluno, com mais objetividade. Às vezes você precisa voltar a outras metodologias que consigam atingir aquele aluno com mais especificidade que o grupo. É quase uma individualização da alfabetização. Chega um determinado momento em que a sua classe está com vários níveis de alfabetização, e aí você tem que dividir em grupos e trabalhar com cada grupo com uma proposta que vai ficar mais adequada e vai te dar mais resultados positivos. (Professora Alzira Rufino - informação verbal)

Olha, a gente tem um discurso, uma pegada que é documentalmente socioconstrutivista, a gente vê isso o tempo todo nesse documento, as pessoas acham bonito dizer isso, enfim, os próprios documentos oficiais curriculares, flertam, flertam não, têm textualmente esses fundamentos do sócioconstrutivismo, mas sempre vou ser chato com isso, eu não acho que, na prática, a gente chegou nem perto disso. Mas eu acho que é isso, esses são os fundamentos que Caxias defende. (Orientador Pedagógico Abdias Nascimento - informação verbal)

Eu acho que, como em todo lugar, ele é misto, assim. Não há nenhum lugar que seja puro, digo, na prática. Caxias fala muito de uma perspectiva oficial que nos documentos ela é construtivista, mas que, materialmente, ela não conseguiria trabalhar apenas com construtivismo. Falta material pedagógico, os espaços e os tempos escolares também não contribuem para 
um trabalho construtivista. Você tem salas muito lotadas, uma série desses complicadores mesmo, de cada grupo, que acaba o professor tendo que improvisar uma coisa meio mista, ele deve, tanto um pouco da sua formação também, que Caxias não dá, porque ele fala que é construtivista, mas a gente tem, pelo menos eu cheguei em 2007. Eu acho que 2007 foi o último curso da Secretaria de Educação, não tenho certeza, mas eu não lembro de nos outros anos terem tido também, não. Então, nesse sentido, oficialmente, ela é construtivista, a Rede é, mas, na prática, ela é uma mistura de coisas, ela não é uma coisa única. (Professor Ferreira Gullar - informação verbal)

Para o professor Ferreira Gullar, a dificuldade de se alinhar a prática pedagógica às concepções curriculares se deve, em parte, à formação dos professores, ou melhor, à falta de oferta de formação continuada aos professores da rede, além de condições inadequadas de espaços e tempos escolares, bem como de materiais didáticos.

Assim, pelos relatos, os profissionais da rede de ensino de Duque de Caxias conhecem as concepções teóricas que fundamentam o currículo de Duque de Caxias, mas apontam que as práticas pedagógicas implementadas no chão da escola nem sempre conseguem se alinhar a essas concepções em função de dois aspectos principais: 1) os níveis diferenciados de aprendizagem dos alunos, como atestou a professora Alzira Rufino, o que leva o professor, muitas vezes, a precisar adotar uma "individualização da alfabetização"; 2) as condições escolares adversas, como falta de materiais didáticos, espaços escolares e falta de oferta de formação por parte da SME/Duque de Caxias, como relatou o professor Ferreira Gullar.

Sobre este aspecto, foi perguntado aos entrevistados "Quais cursos, congressos e eventos foram organizados nos últimos 2 (dois) anos pela SME de Duque Caxias/RJ com a temática 'alfabetização' que você tenha participado?"

O professor Ferreira Gullar apontou que não participou de nenhuma atividade de formação e destacou que a SME/Duque de Caxias não ofereceu.

Que eu tenha participado, nenhum. E, até onde eu sei, eu posso estar enganado, a SME não tem oferecido cursos nenhum de Alfabetização, eu acho que de nada... Matemática... Enfim, não tenho memória desse tipo de informação, não. Ou você vai fazer por conta própria, não, por conta própria que eu digo, se matricular no curso que você contratou e fazer ou ... da SME, sinceramente, não. Eu acho que, pelo menos na formação, eu não lembro mais o nome, se era alfa, de alfabetização que eu fiz em 
2007, eu fiz (...) assim que cheguei na Rede. (Professor Ferreira Gullar - informação verbal)

Os relatos da professora Alzira Rufino e da orientadora pedagógica Cora Coralina confirmam a denúncia do professor Ferreira Gullar sobre a falta de formação continuada para os professores da rede.

Olha, os últimos cursos de alfabetização que eu participei, eu não lembro de ter feito nenhum outro curso. Não sei se teve, porque como eu te falei, estava com educação infantil, pode ser que tenha tido e eu não esteja lembrando, pois não fui contemplada. (Professora Alzira Rufino - informação verbal)

Nossa, eu fiquei pensando aqui para não ser injusta, mas, na verdade, eu não estou sendo injusta. Eu ingressei pelo concurso de Caxias de 2016, e até as colegas que são da Rede há mais tempo falam "Nossa, Caxias não era assim, nós tínhamos muitas formações, muitos encontros, muitos congressos", e, infelizmente, eu não peguei esse período de vacas gordas, eu cheguei no período de vacas magras, onde até salário nosso ficou em atraso. Então, eu não me recordo de nenhum encontro de formação, congresso grande, não lembro. Eu lembro de reuniões voltadas para orientação pedagógica e, nessas reuniões, acaba que a gente fala sobre alfabetização, mas um congresso voltado para alfabetização não houve nesses dois últimos anos. Os grupos de estudo, pelo calendário da Secretaria de Educação, são apenas quatro, durante todo o ano letivo. É um número ínfimo que não dá conta da formação do professor. (Orientadora Pedagógica Cora Coralina -informação verbal)

Em certa medida, o documento Reestruturação curricular: texto introdutório reconhece essa fragilidade ao apontar a necessidade de "mais investimento público na infraestrutura e na valorização docente para que se alcance um trabalho em prol da emancipação humana” (DUQUE DE CAXIAS, 2020, p. 38).

Inclusive, quando os entrevistados foram perguntados sobre as causas para a não alfabetização das crianças, todos apontaram as condições de infraestrutura das escolas e a falta de investimento na formação do professor. Somados a esses dois aspectos, os entrevistados apontaram também as condições externas à escola, como violência, trabalho e pobreza, como obstáculos. 
Inúmeros fatores, mesmo. $\mathrm{O}$ principal seria o ambiente inadequado, porque nós sabemos que muitas salas de aula da nossa rede não são um ambiente estimulador, não é um ambiente que vai ser favorável à alfabetização, então a gente tem as questões estruturais, temos as questões familiares, de violência que, às vezes, impede das crianças a estarem nas salas de aula. A gente tem também as crianças que, desde cedo, já trabalham para ajudar os pais em casa, aí faltam às aulas para estar nos sinais vendendo alguma coisa, de alguma forma. Depois do Bolsa Família, até que tivemos uma queda, nessa relação, mas são muitos fatores que vão contra a alfabetização, a gente tem que estar quebrando portas, paredes também. (Professora Alzira Rufino - informação verbal)

$\mathrm{Eu}$ acho que ainda tem que ter muito investimento na formação do professor para melhorar isso. Então a gente tem a pobreza extrema da maioria dos alunos de Duque de Caxias, a falta de um ambiente letrado, desse incentivo da família, dessa participação da família, e a gente também precisa ainda investir sempre na formação do professor, coisa que Caxias não vem fazendo nos últimos anos. (Professora da Sala de Leitura Clarice Lispector - informação verbal)

Nessa mesma dimensão de análise, Gontijo (2008, p. 33) afirma que “(...) o que caracteriza o processo de alfabetização como histórico-cultural é o fato de os elementos constitutivos desse processo serem resultado de práticas sociais e essa se constituir também como prática social”.

Como eu falei, eu acho que o professor precisa aprender sobre tudo, sobre todos os métodos, é soletração, é o silábico, é o global, é o sintético, aprender sobre tudo, porque ele não sabe como vai ser a criança que ele vai encontrar, e as crianças, cada uma é uma, com sua história, com sua dificuldade, com seu talento. Então, quanto mais conhecimento o professor tiver, para poder alcançar o objetivo principal, que é o aprendizado do aluno. (Orientadora Pedagógica Cora Coralina - informação verbal)

\section{3}

Eixo 3) Conhecimento dos professores sobre as concepções de alfabetização presentes nos documentos curriculares da rede de ensino e na BNCC 
Para verificar se os professores sabem quais são as concepções que fundamentam a concepção de alfabetziação presente nos documentos curriculares da rede de ensino de Duque de Caxias e da BNCC, perguntamos, primeiramente: "Quais concepções teóricas de alfabetização fundamentaram o novo currículo em construção?"

Para o professor Ferreira Gullar, o curriculo de Caxias vai retomar os pressupostos do método fônico, sem abandonar os pressuspostos do construtivismo e do sociointeracionismo.

É o método fônico, o retorno é ele. Mas eu acho também que o construtivismo não vai se perder como um todo desse processo. Acho que tem uma série de princípios no sociointeracionismo, no construtivismo, do trabalhando em dupla, uma série de perspectivas que elas vão permanecer, esvaziadas, em certa medida, porque você vai ter a questão do método fônico. Mas eu acho que, como pesquisador, vai ser interessante perceber o que fica implantado, o que ficou plasmado do construtivismo nesses anos todos e ficou de tal forma sedimentado. (Professor Ferreira Gullar - informação verbal)

Compreende-se desse modo que a correlação em qualquer documento curricular se dá pela natureza e dinâmica das experiências docentes, que são igualmente múltiplas. Não se pode falar que a escolha de uma perspectiva teórica, pressuposto metodológico ou um método em si, seja posto como uma referência única ou superior a outros. Assim, a relevância das linhas teóricas e princípios sociointeracionistas ou construtivistas transitam no documento de referências curriculares do município. Portanto, este estudo vem demostrando principalmente nos capítulos de revisão de literatura abordagens que ganham maiores expressividade de tempo em tempo demostrando a necessidade de existir pesquisas sobre o tema e sugestões de novas abordagens, concepções e metodologias.

Já para a orientadora pedagógica Cora Coralina, o documento curricular de Duque de Caxias vai continuar se embasando nas teorias presentes nos currículos anteriores.

Pelo que eu percebi, alguns professores, orientadores, eles, na verdade, continuam com a base teórica de Paulo Freire, de Vygotsky, Piaget, eles vão dar continuidade a essa mesma base 
teórica. (Orientadora Pedagógica Cora Coralina - informação verbal)

Desse modo, a orientadora pedagógica Cora Coralina, ressalta importância de teóricos e teorias bem fundamentadas, sendo que algumas estão fundamentadas em teóricos históricos culturais, e também autores de fundamentação marxista, relevante para análise da totalidade social, que, tem na experiência de construção da própria língua, um caráter politizador.

Dos entrevistados, dois afirmaram não ter acesso ao novo currículo, que está em elaboração na rede de ensino, mas acreditam que ele não vai apresentar mudanças significativas em relação ao currículo anterior. Nessa relação entre a experiência didática curricular experienciada no cotidiano dos professores e os documentos dos anos de 2002 e 2004, pode-se dizer que tais pressupostos anteriores resultaram em descrever nos documentos as perspectivas socioconstrutivistas, e por isso, não trouxeram o incômodo ou estranhamento quando, de certo modo, foram reprisado no documento atual.

Pelo que eu observei, continua a concepção sociointeracionista. Pode ser que eu esteja errada, não vi mudanças nessa temática não. (Professora da Sala de Leitura Clarice Lispector informação verbal)

Eu acho que muda pouco, sinceramente. Eu acho que, na prática, muda menos ainda. Não é a FEBF que tem que dizer o que eu tenho que ensinar. É a comunidade escolar que tem que discutir comigo o que é importante ensinar. Na prática, a gente olha para o professor universitário e acha que ele é o conhecimento, que ele vai dizer melhor do que eu o que eu tenho que ensinar para os meus alunos, sem ele nunca ter entrado numa sala de aula para dar aula. Então, eu vejo pouca diferença, principalmente na prática, eu acho que não tem diferença nenhuma, mas, na teoria, eu também acho que tem pouca diferença entre o texto dos documentos anteriores e esse texto. Vai ser uma roupa nova, uma roupa bonitinha. (Orientador Pedagógico Abdias Nascimento informação verbal)

Já para a professora Alzira Rufino, o novo currículo deve apresentar mudanças significativas, embora ela ainda não tivesse acessado o documento Reestruturação curricular: texto introdutório. 
Com esse novo que está sendo elaborado, não tenho muito acesso a esse novo, mas creio que vai ter muita mudança e que vai ser um olhar mais direcionado para o aluno, porque muitos professores estão podendo participar, estão podendo opinar nessa mudança, nessa reestruturação. Dessa forma, eles estão levando para as escolas. (Professora Alzira Rufino - informação verbal)

Trata-se apenas de uma percepção da professora Alzira pelos diálogos que ela já vem estabelecendo com aqueles que participam da reconfiguração do novo documento. E que ao mesmo tempo, traz sua maturidade na compreensão de que o currículo, em movimento, merece as adequações/adaptações no tempo histórico que se propõe. Nesse sentido, o avanço e mudanças são relativamente importantes, não por se tratar de uma nova proposta ou de novos pressupostos, mas de novas adequações a um público alvo que é outro.

O orientador pedagógico Abdias destaca que não tem o que dizer uma vez que "a comunidade escolar é que tem que discutir sobre o que é importante ensinar." Nesse sentido, o orientador pedagógico reafirma o papel da comunidade escolar na discussão do currículo, bastante valorizado neste processo de reestruturação curricular, pelo menos no discurso normativo, como discutido no capítulo 2 .

Por fim, perguntamos aos entrevistados se eles sabiam quais são as aproximações e/ou distanciamentos entre as concepções de alfabetização da reestruturação curricular e da Base Nacional Comum Curricular/BNCC.

A professora Alzira Rufino, o professor Ferreira Gullar e a professora Clarice Lispector disseram não ter acompanhado as discussões e, por isso, não sabem dizer quais são as aproximações ou distanciamentos entre o currículo municipal e o nacional.

Eu não vou nem correr o risco de ser leviano, porque aí é um distanciamento que eu tenho, do que está sendo discutido, muito grande. A BNCC a gente começou a conhecer, eu falei que conheço no sentido de que já li, a gente já usou na escola para poder fazer, a gente já até usou ela para fazer o plano de curso, mas eu não tenho acompanhado a discussão da reestruturação curricular. Então ainda é muito incipiente, não conheço nem as concepções da BNCC, profundamente, tampouco o que está sendo discutido na reestruturação curricular. (Orientador 
Pedagógico Abdias Nascimento - informação verbal)

Essa é uma pergunta difícil de responder. Eu não saberia, agora, responder, mas eu acho que, como eu falei, perde muita coisa. O que fica, o que aproxima, eu acho que o que vai ficar é muito daquilo que ficou sedimentado, o que se tornou muito dessa proposta dos últimos anos. Eu acho que, como prática do professor em sala de aula, da organização professor em sala de aula, eu acho que aí que vai sofrer as maiores mudanças. Eu acho que vem uma coisa mais esquematizada, mas alguns princípios do construtivismo, por exemplo a Zona de Desenvolvimento Proximal, eu acho que isso fica, eu acho que isso não chega a ser um problema, uma questão. A questão do trabalho com texto também acho que não é uma coisa que deve sair não, que deve sumir não, até porque, se você pensar assim, a Escola Nova já tinha essa posição do trabalho com texto. Então, eu acho que alguns elementos ficam, mas eu acho que perde mais na organização do trabalho escolar do professor ao longo do ano, como ele vai se organizar, eu acho que vem uma coisa mais engessada nesse sentido. (Professor Ferreira Gullar informação verbal)

Eu não li a reestruturação curricular de Caxias toda. Eu não sei, isso não foi discutido na minha escola. Eu não sei se as outras escolas fizeram essa discussão. O que chegou para mim era para responder sobre a educação infantil, para ver o que eu concordava, o que eu não concordava, e já veio tudo pronto para dizer o que eu concordava e o que eu não concordava, e tudo alinhado com a BNCC, inclusive algumas partes lá são os termos, as palavras, parece que copiaram e colocaram no documento. (Professora da Sala de Leitura Clarice Lispector - informação verbal)

Já para a orientadora pedagógica Cora Coralina, o novo documento curricular de Caxias deve se aproximar da BNCC.

Como eu falei, acho que aproximação na matriz curricular continua a questão de habilidades e competências que há na BNCC. (Orientadora Pedagógica Cora Coralina - informação verbal)

O que se observa pelos relatos é que os entrevistados não sabem muito bem quais são as aproximações e os distanciamentos entre o currículo nacional e o municipal, pois não tiveram acesso aos documentos e, quando tiveram, não leram na íntegra e nem atentos aos elementos que são comuns e diferentes em ambos os 
currículos.

Considera-se, portanto, que, dada às circunstâncias, provocadas pela pandemia da Covid19, no ano de 2020, as inúmeras dificuldades encontradas, para que encontros virtuais acontecessem, como, por exemplo, a falta de estrutura que muitos docentes têm em suas próprias residências, com o estabelecimento e acesso a uma internet condizente, impossibilitando assim a participação e a opinião de todos. Nesse sentido, toda condição material objetiva para que tal participação fosse democraticamente composta, não pode ser alvo de culpabilização dos docentes ou da rede municipal, mais dado o contexto.

Cabe destacar que esse documento ainda em andamento tem muito a representar diferentes setores, perspectivas teóricas, os interesses das comunidades, representações de movimentos sociais da sociedade civil, dentre tantas outras demandas que envolvem a pluralidade étnico, racial, e circunstanciada num município tão diverso como o de Caxias. 


\section{Considerações finais}

Apesar das dificuldades provocadas pela pandemia do novo coronavírus, de um modo geral, pode-se concluir que este estudo conseguiu alcançar os objetivos propostos por meio do levantamento e da análise dos dados. Isso porque os resultados permitiram uma melhor compreensão sobre as concepções de alfabetização de três professores alfabetizadores, bem como de dois coordenadores pedagógicos da rede municipal de educação de Duque de Caxias/RJ. Além disso, o estudo também conseguiu identificar as principais bases teóricas de alfabetização apresentadas nos documentos curriculares Pressupostos Teóricos Filosóficos (de 2002), Propostas Pedagógicas (2004) e na minuta Reestruturação Curricular: texto introdutório, ainda em construção coletiva.

$\mathrm{O}$ estudo também avaliou as concepções presentes na BNCC e como os profissionais da educação da rede de Caxias percebem a sua influência na reestruturação curricular em curso na rede de ensino.

De um modo geral, o estudo chegou a alguns resultados interessantes:

1) A BNCC não parece privilegiar as concepções construtivista e sociointeracionista como os Parâmetros Curriculares Nacionais;

2) A BNCC foi uma das principais razões que motivou a rede de ensino de Duque de Caxias a reestruturar seu currículo. No entanto, embora motivadora, a BNCC não parece ser, pelo documento Reestruturação curricular: texto introdutório e pelos relatos dos entrevistados, uma referência para a construção desse novo currículo;

3) Embora a pandemia tenha atrapalhado, o novo currículo da rede de ensino está sendo construído de forma coletiva, com a participação de todos os profissionais da rede, por meio de grupos de estudo e grupos de trabalho;

4) O novo currículo parece se ancorar em teorias pós-críticas de currículo;

5) A pandemia provocada pelo novo coronavírus fez com que as atividades do processo de reestruturação fossem adaptadas para a modalidade on-line, o que dificultou a participação dos profissionais nas atividades e, consequentemente, a construção coletiva do currículo. A despeito disso, há indícios de que a não participação de alguns profissionais deve-se à descrença nas políticas educacionais da rede de ensino de Duque de Caxias;

6) Os profissionais conhecem as concepções teóricas que fundamentam os 
documentos curriculares da rede de ensino, Duque de Caxias (2002; 2004), mas apontam as dificuldades em implementar práticas pedagógicas alinhadas a essas concepções, ou seja, o currículo na prática. As principais dificuldades apontadas foram as condições inadequadas da infraestrutura escolar e a falta de oferta de formação continuada aos professores Desta forma, observa-se um distanciamento entre o currículo prescrito nos documentos oficiais nacionais e municipais e o currículo real, implementado nas salas de aulas das escolas de Duque de Caxias.

7) Embora conheçam as concepções teóricas dos documentos curriculares, a compreensão delas ainda é confusa para a maioria dos entrevistados;

8) Alguns entrevistados se mostraram a favor da adoção de práticas pedagógicas alinhadas ao método fônico;

9) De uma maneira geral, os professores não sabem dizer se a construção do novo currículo está em consonância com as concepções de alfabetização e de currículo da BNCC.

Em que pese os limites deste estudo, que foi atravessado pela medida de distanciamento social provocada pela pandemia, os achados desta pesquisa nos permitem considerar a dúvida sobre a implementação da $\mathrm{BNCC}$ nas redes de ensino locais, uma vez que, pelo menos em Duque de Caxias/RJ, parece haver certa resistência à $\mathrm{BNCC}$, pois o processo de revisão do currículo parece não levar em conta as orientações do documento nacional. Ao contrário, parece se fundamentar mais nos currículos anteriores da rede e, também, nas percepções e concepções que os profissionais do chão da escola possuem sobre a alfabetização e a aprendizagem. 


\section{Referências}

BARDIN, L. Análise de conteúdo. Lisboa: Edições 70, 1977.

BATISTA, A. A. G e RIBEIRO, W. M. Consensos e dissensos em torno de uma Base Nacional Comum Curricular no Brasil. Relatório de Pesquisa. São Paulo, 2015. Disponível em: https://www.scielo.br/pdf/edur/v36/1982-6621-edur-36e220676.pdf. Acesso em 11 jan. 2021.

BECKER, F. O que é o construtivismo? In: Ideias, n. 20. São Paulo: FDE. p. 8793, 1994. Disponível em: <http:// www.crmariocovas. sp.gov.br/ pdf/ideias_20_p087-093_c.pdf $>$. Acesso em 10 de mar. de 2020.

BONAMINO, A.; MUYLAERT, N.; PONTES, L. A. F. A (Des)Igualdade de conhecimento no ciclo de alfabetização. Estudos em Avaliação Educacional (Online), v. 29, p. 78, 2018. Disponível em: < http://publicacoes fcc.org.br/index. php/eae/article /view/4050/3557>Acesso em 10 de jan. 2021.

BOTO, C. Alfabetização: entre o método fônico e o construtivismo, a necessidade de reconstruir o debate. Jornal da USP, São Paulo, 03 maio 2019. Disponível em: https://jornal.usp.br/artigos/alfabetizacao-entre-o-metodo-fonico-e-oconstrutivismo-a-necessidade-de-reconstruir-o-debate/. Acesso em 19 mai. 2020.

BRASIL. IBGE. Censo Demográfico, 2017. Disponível em $<$ https://cidades. ibge.gov.br/brasil/rj/duque-de-caxias/panorama>. Acesso em 05 jun. 2020.

BRASIL. Base Nacional Comum Curricular: Educação é a base. Brasília, 2017. Disponível em < http://basenacionalcomum.mec.gov.br/download-da-bncc/>. Acesso em 14 jan. 2020.

Lei n.13.005, de 25 de junho de 2014. Aprova o Plano Nacional de Educação - PNE e dá outras providências. Diário Oficial [da] República Federativa do Brasil. Brasília, DF, 26 junho de 2014. Disponível em: http: //www. planalto. gov.br/ccivil_03/_ato2011-2014/2014/lei/113005.htm. Acesso em 14 de jan. 2020.

Constituição da República Federativa do Brasil de 1988. Disponível em: http://www.planalto.gov.br/ccivil_03/constituicao/constituicaocompilado.htm Acesso em 14 jan. de 2020.

Lei no 9.394, de 20 dezembro de 1996a. Estabelece as Diretrizes e Bases da Educação Nacional. Disponível em: http://www.planalto.gov.br/leis/L9394. Acesso em: 14 de jan. 2020.

Ministério da Saúde. Conselho Nacional de Saúde. Resolução n ${ }^{\circ}$ 196, de 10 de outubro de 1996b. Diretrizes e Normas Regulamentadoras de pesquisa envolvendo seres humanos. Disponível em: http:// conselho.saude.gov.br 
/resoluções /1996.pdf. Acesso em: 03 Abr. 2019.

DECRETO No 9.765, DE 11 DE ABRIL DE 2019. Disponível em: http://www.planalto.gov.br/ccivil_03/_ato2019-2022/2019/decreto/D9765.htm Acesso em: 23 abr. 2019.

Parâmetros Curriculares Nacionais: Língua Portuguesa. Brasília: MEC/SEF, 1997.

Lei $n^{\circ}$ 9.795, de 27 de abril de 1999. Dispõe sobre a Educação Ambiental, institui a Política Nacional de Educação Ambiental e dá outras providências. Diário Oficial [da] República Federativa do Brasil. Brasília, DF, 28 abr. 1999. Disponível em: http://www.planalto.gov.br/ccivil_03/LEIS/L9795.htm. Acesso em: 14 jan. 2020.

Lei ${ }^{\circ}$. 11.645/2008, de 10 de março de 2008. Altera a lei n. 9.394, de 20 de dezembro de 1996, modificada pela lei n. 10.639, de 9 de janeiro de 2003, que estabelece as diretrizes e bases da educação nacional, para incluir no currículo oficial da rede de ensino a obrigatoriedade da temática "História e Cultura AfroBrasileira e Indígena". Diário Oficial [da] República Federativa do Brasil. Brasília, DF, 11 mar. 2008. Disponível em http://www.planalto.gov.br /ccivil_03/Ato 2007-2010/2008/Lei/L11645.htm. Acesso em 14 jan. 2020.

. Lei $\mathrm{n}^{\mathrm{o}} 10.639$, de 9 de janeiro de 2003. Altera a lei $\mathrm{n}^{\circ} 9.394$, de 20 de dezembro de 1996, que estabelece as diretrizes e bases da educação nacional, para incluir no currículo oficial da rede de ensino a obrigatoriedade da temática "História e Cultura Afro-brasileira", e dá outras providências. Diário Oficial [da] República Federativa do Brasil. Brasília, DF, 9 jan. 2003. Disponível em: http://www.planalto.gov. Brccivil_03/leis/2003/110.639.htm. Acesso em 14 jan. 2020.

Guia de implementação da Base Nacional Comum Curricular. Disponível em: http://implementacaobncc.com.br/guiadeimplentacao2018.pdf. Acesso em 14 jan. 2020 .

CAGLIARI, L. C. Alfabetização: o duelo dos métodos. In: SILVA, E. T. (Org.). Alfabetização no Brasil: questões e provocações da atualidade. Campinas: Autores Associados, 2007.

Alfabetização e Linguística. 5. ed. São Paulo: Scipione, 1992.

CAPOVILLA, A. Alfabetização: método fônico. $4^{\mathrm{a}}$ Edição. São Paulo: Memnon, 2007.

CARVAlHO, C. Percepção dos Professores do Ensino Fundamental sobre o

Ensino da Leitura. Mestrado em Psicologia Educacional. Instituição de Ensino: Centro Universitário FIEO. Disponível em: https://sucupira.capes.gov.br/public /consultas/coletas/trabalhoConclusao/.jsf?popup=true\&id_trabalho=7224887.

Acesso em 10 de mar. 2020.

CARVALHO, M. Alfabetizar e Letrar: Um diálogo entre a teoria e a prática. $5^{\mathrm{a}}$ 
Ed. Rio de Janeiro: Vozes, 2008.

COSTA, V. Base Nacional Comum Curricular como política de regulação do currículo, da dimensão global ao local: o que pensam os professores? Doutorado em Educação. Instituição de Ensino: Pontifícia Universidade Católica de São Paulo. Disponível em: https://sucupira.capes.gov.br /public/consultas /coletas/trabalhoConclusao/viewTrabalhoConclusao.jsf?popup=true\&id_trabalho= 7927297. Acesso em: 10 de mar. 2020.

DUARTE, C. S. Direito público subjetivo e políticas educacionais. São Paulo em Perspectiva. São Paulo, vol.18, n.2, pp.113-118, abr/jun, 2004.

DUARTE, R. Entrevistas em pesquisas qualitativas. Educ. rev., Curitiba, n. 24, p. 213-225,2004. Disponível em: https://www.scielo.br/scielo.php?pid=S010440602004000200011 \&script=sci_abstract\&tlng=pt> Acesso em 14 out. 2020.

DUQUE DE CAXIAS. Reestruturação Curricular Texto Introdutório. Duque de Caxias, RJ: SME, 2020. Disponível em: http://smeduquedecaxias. rj.gov.br/smeportal/wp-content/uploads/2020/06/TEXTO-Reestrutur.pdf. Acesso em 14 Out. 2020.

. Lei $\mathrm{n}^{\mathrm{o}} 2.864$, de 01 de novembro de 2017. Aprova a gestão democrática da educação pública e dá outras providências. Diário Oficial do Município de Duque de Caxias, RJ. Disponível em: http://duquedecaxias.rj.gov.br/portal/ arquivos/novembro/Boletim _ 6475.pdf. Acesso em 14 jan. 2020.

Lei $n^{\circ} 2.713$, de 30 de junho de 2015. Aprova o Plano Municipal de Educação - PME e dá outras providências. Diário Oficial do Município de Duque de Caxias, RJ. Disponível em: http://duquedecaxias.rj.gov.br/portal /boletimoficial /2015/30-Junho/6241-30.pdf. Acesso em 14 jan. 2020.

. Secretaria Municipal de Educação. Trajetória do Ciclo de Alfabetização na Rede de Ensino de Duque de Caxias. SME, 2006. Disponível em: http://smeduquedecaxias.rj.gov.br/nead/Biblioteca/Produ\%C3\%A7\%C3\%B5es $\% 2$ 0SME/Cadernos $\% 20$ de $\% 20$ Atividades $\% 20$ Pedag $\%$ C3\%B3gicas/Caderno $\% 20$ te $\%$ C3\%B3rico.pdf. Acesso em 14 de mai. 2020.

Secretaria Municipal de Educação. Pedagógica da Secretaria de Educação de Duque de Caxias: Volume 2: Proposta Pedagógica Duque de Caxias, RJ: SME, 2004. Disponível em: http://sistemas.smeduquedecaxias.rj.gov.br:70/. Acesso em 14 mai. 2020.

. Proposta Pedagógica da Secretaria de Educação de Duque de Caxias: Volume 1: Pressupostos Teóricos Filosóficos. Duque de Caxias, RJ: SME, 2002. Disponível em: http://sistemas.smeduquedecaxias.rj.gov.br:70/ Acesso em 14 mai. 2020.

ESTEBAN, M.T. Considerações sobre a política de avaliação da alfabetização: pensando a partir do cotidiano escolar. Revista Brasileira de Educação (Impresso), v. 17, p. 573-592, 2012. 
FERREIRO, E. Com todas as letras. São Paulo: Cortez, 1992.

. Reflexões sobre alfabetização. São Paulo: Cortez, 1990.

. Alfabetização em processo. São Paulo: Cortez, 1988.

Médicas, 1985.

TEBEROSKY, A. Psicogênese da Língua Escrita. Porto Alegre: Artes

FRADE, I. C. A. da S. Métodos de alfabetização, métodos de ensino e conteúdos da alfabetização: perspectivas históricas e desafios atuais. Educação. Santa Maria, v. 32, n. 01, p. 21-40, 2007. Disponível em: http://www.ufsm.br/ce/revista. Acesso em 05 de mai. 2020.

Métodos e didáticas de alfabetização: história, características e modos

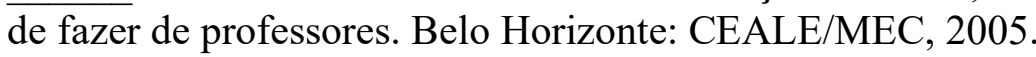

Escolha de livros de alfabetização: dialogando com permanências históricas e com modelos atuais de inovação. História da Educação, Pelotas, v. 7, n. 14 , set. 2003a.

. Alfabetização hoje: onde estão os métodos? Presença Pedagógica, Belo Horizonte, v. 9, n. 50, mar/abr. 2003b.

Mudança e resistência à mudança na escola pública: análise de uma experiência de alfabetização "construtivista". 1993 Dissertação (Mestrado) Faculdade de Educação, Universidade Federal de Minas Gerais, Belo Horizonte, 1993.

FREIRE, P. Pedagogia dos sonhos possíveis. $1^{a}$ ed. Rio de Janeiro: Paz \& Terra, 2014

Pedagogia da Indignação: cartas pedagógicas e outros escritos. São Paulo: UNESP, 2000a.

A educação na cidade. $4^{\mathrm{a}}$ ed. São Paulo: Cortez, $2000 \mathrm{~b}$.

Pedagogia da autonomia: saberes necessários à prática educativa. 23 . ed. São Paulo: Paz e Terra, 1996.

Educação como Prática da Liberdade. Rio de Janeiro: Paz e Terra, 1989.

Educação e Mudança (10a ed.). Rio de Janeiro: Paz e Terra, 1985.

- Conscientização e alfabetização: uma nova visão do processo. In: FÁVERO, O. (Org.). Cultura popular, educação popular: memória dos anos 60. Rio de Janeiro: Graal, 1983.

. A Importância do Ato de Ler. São Paulo: Autores Associados, 1981.

Pedagogia do Oprimido. (2a ed.). Porto: Afrontamento, 1975. 
GALIAN, C. V. A. Os PCN e a elaboração de propostas curriculares no Brasil. Cadernos de Pesquisa (Fundação Carlos Chagas. Impresso), v. 44, p. 648-669, 2014.

GERALDI, João Wanderley. O ensino de língua portuguesa e a Base Nacional Comum. Revista Retratos da Escola. Brasília, v. 9, n. 17, p. 381-396, jul./dez. 2015. Disponível em: http://www.esforce.org.br/ Acesso em: 13 abr. 2020.

GONTIJO, C. M. M. A escrita infantil. São Paulo: Cortez, 2008.

INEP. Avaliação Nacional da Alfabetização: relatório 2013- 2014: volume 2: análise dos resultados. Brasília: Inep, 2015.

JAMES, Allison. Constructing Childhood: theory, policy and social practice. New York: Palgarve Macmillan, 2004.

JENKS, Chris. Childhood. New York: Routledge, 2005.

KRAMER, SONIA; SOUZA, S. O Debate Piaget/Vygotsky e as Políticas Educacionais. Cadernos de Pesquisa. Fundação Carlos Chagas, v. 77, p. 69-80, 1991. Disponível em: http://publicacoes.fcc.org.br/index.php/cp/article/view/1044 Acesso em 7 mar. 2021.

LOPES, A. C. Teorias Pós-Críticas, Política e Currículo. Educação, Sociedade e Culturas, n.39, 2013, pp 7-23.

LUDKE, M. e ANDRÉ, M. E. D. A. Pesquisa em educação: abordagens qualitativas. São Paulo: EPU, 1986.

LURIA, A. R.; LEONTIEV, A. N. Linguagem, desenvolvimento e aprendizagem. 7. ed. São Paulo: Ícone, 2001. p. 103-119.

MARSIGLIA, A. C. G.; PINA, L. D.; MACHADO, V. de O.; LIMA, M. A base nacional comum curricular: um novo episódio de esvaziamento da escola no Brasil. Germinal: Marxismo e Educação em Debate, Salvador, v. 9, n. 1, p. 107-121, abr, 2017.

MELLO, A.P. Políticas para Educação Infantil: O lugar da Consciência Fonológica na Base Nacional Comum Curricular. Dissertação em Educação. Universidade Regional Integrada do Alto Uruguai e das Missões. Rio Grande do Sul. Disponível em: https://sucupira.capes. gov.br/sucupira/publica /consultas /coleta/trabalhoConclusao/viewTrabalhoConclusao.jsf?popup=true\&id_trabalho= 6509694. Acesso em 10 mar. 2020.

MICARELLO, H. A. L. S. A BNCC no contexto de ameaças ao estado democrático de direito. Eccos revista científica (online), v. 0, p. 61-75, 2017. Disponível em: https://periodicos.uninove.br/eccos/article/view/6801/3429. Acesso em 12 de nov. 2020. 
Bakhtiniana: Revista de Estudos do Discurso, v. 9, p. 150-163, 2014.

MORAIS, A. G. Se a escrita alfabética é um sistema notacional (e não um código), que implicações isto tem para a alfabetização? In: MORAIS, A. G; ALBUQUERQUE, E.B.C; LEAL, T.F (Org.) - Alfabetização: apropriação do sistema alfabético. Belo Horizonte: Autêntica, 2005.

A apropriação do sistema de notação alfabética e o desenvolvimento de habilidades de reflexão fonológica. Letras de Hoje, Porto Alegre, v. 39, n. 3, p. 3548, 2004.

MOREIRA, A. F. B. Os Parâmetros Curriculares Nacionais em questão. Educação \& Realidade, v. $21 \mathrm{n}^{\circ} 1$, p. 9-23, 1996.

MORIN, E. Os sete saberes necessários à Educação do futuro. São Paulo. Ed. Cortez, 2000.

MORTATTI, M. R. L. Os órfãos do construtivismo. REVISTA IBEROAMERICANA DE ESTUDOS EM EDUCAÇÃO, v. 11, p. 2267-2286, 2016.

Função social da escola: aspectos históricos e metodológicos da alfabetização. In: CHAVES, M.; SETOGUTI, R.; VOLSI, M.A. Função Social da escola: das políticas públicas às práticas pedagógicas. Maringá: Ed. Da UEM, 2011, p. 35-60.

História dos métodos de alfabetização no brasil. Conferência proferida durante o Seminário "Alfabetização e Letramento em debate", promovido pelo Departamento de Política de Educação Infantil e Ensino Fundamental da Secretaria de Educação Básica do Ministério da Educação, Brasília, 2006.

Educação e Letramento. São Paulo: UNESP, 2004.

Os sentidos da alfabetização: São Paulo, 1876-1994. São Paulo: Ed. UNESP; CONPED, 2000.

MUYLAERT, 2020, p. 9-10. No prelo. Revista Pesquisa e Debate em Educação.

MUYLAERT, N. Contribuições da Ciência Política para o campo educacional: o burocrata de nível de rua. Educação on-line (PUC-RJ), v. 14, p. 1-9, 2019.

NAKAD, F. A. Desafios para a implementação da Base Nacional Comum Curricular. 2017. Mestrado Profissional em Gestão e Políticas Públicas. Instituição de Ensino: Escola de Administração de Empresas de São Paulo. Disponível em: https://sucupira.capes. gov.br/public /consultas /coletas/trabalho viewTrabalhoConclusao.jsf?popup=true\&id_trabalho=5897292. Acesso em: 13 abr. 2020.

OLIVEIRA, D. A.; SOUSA, S.M.Z.L. 1996. Currículo nacional e avaliação: elementos para uma discussão. In: Revista de Educação AEC. Ano 25, $\mathrm{n}^{\mathrm{o}}$ 100, jul/set, p. 148-166. 
OLIVEIRA, L. H. Habilidades de leitura e práticas de leitura associadas ao seu aprendizado. Tese de Doutorado, 2012, 158 fls. Programa de Pós-Graduação em Educação. Pontifícia Universidade Católica do Rio de Janeiro (PUC-Rio), 2012.

PERTUZATTI, I. Alfabetização e letramento nas políticas públicas: convergências e divergências com a BNCC. 2017. Mestrado em Educação. Instituição de Ensino: Universidade Comunitária da região de Chapecó. Disponível em:https://sucupira.capes.gov.br/public/consultas/coletas/trabalhoConclusao/view TrabalhoConclusao.jsf?popup=true\&id_trabalho $=6897297$. Acesso em 10 de mar. 2020 .

PIAGET, J. Psicologia e epistemologia: por uma teoria do conhecimento. Trad. A. Cretella. Rio de Janeiro: Forense. Orig. em francês: 1970.

. Seis Estudos de Psicologia. $24^{\circ}$ edição. Rio de Janeiro: Forense

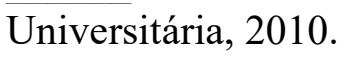

PRESTES, ZOIA. Quando não é quase a mesma coisa: Análise de traduções de Lev Semionovitch Vigotski no Brasil Repercussões no campo educacional. Tese em Educação, Instituição de Ensino: Universidade de Brasília. Disponível em: https://sucupira.capes.gov.br/sucupira/publica/consultasrabalhoConclusao/viewtra balho=5130815 Acesso em 10 mar. 2020 .

PROUT, Alan. Reconsiderando a nova sociologia da infância. Caderno de Pesquisa, v.40, n.141, pp. 729-750, 2010.

ROAZZI, A.; Leal, T. F.; CARVALHO, M. R. A questão do método no ensino da leitura e da escrita. Teresina: APECH / UFPI, 1996.

ROCHA, N. Base Nacional Comum Curricular e Micropolítica: analisando os fios condutores. 2016. Mestrado em Educação. Instituição de Ensino: Universidade Federal da Paraíba. Disponível em:https://sucupira. capes.gov.br/ public/consultas /coletas/trabalhoConclusao/viewTrabalhoConclusao.jsf?popup=true\&id_trabalho= 7927297. Acesso em 10 mar. de 2020.

SOARES, M.B. Alfabetização: a questão dos métodos. São Paulo: Contexto, 2016.

Letramento e Alfabetização: as muitas facetas. Revista Brasileira de Educação, São Paulo: Autores Associados, v. 25, 2004, p. 5-17.

Alfabetização e letramento: caminhos e descaminhos. Pátio (Porto Alegre. 1997), v. 8, p. 18-22, 2004.

. A reinvenção da alfabetização. Presença Pedagógica, v. 9, p. 15-21, 2003. ; MACIEL, F. Alfabetização. Brasília: MEC/INEP/Comped, 2000.

VYGOTSKy, L. S. A Formação Social da Mente. São Paulo: Martins Fontes, 2010 .

- Linguagem e desenvolvimento intelectual na idade escolar. In: 
VIGOTSKI, L.S.; LURIA, A.R.; LEONTIEV, A.N. Linguagem, desenvolvimento e aprendizagem. 6. ed. São Paulo: EDUSP, 1998. p. 103-117.

WALlON, H. Do Ato ao Pensamento: ensaios de psicologia comparada. Petrópolis: Vozes, 2008. 


\title{
Anexos
}

\author{
PONTIFÍCIA UNIVERSIDADE CATÓLICA DO RIO DE JANEIRO \\ Departamento de Educação Programa de Pós-Graduação em \\ Educação
}

TERMO DE CONSENTIMENTO LIVRE E ESCLARECIDO PROFESSOR

Prezada/o:

Eu, Tatiane Rodrigues Souza, RG 20429759-2 aluna do Programa de PósGraduação da Pontifícia Universidade Católica do Rio de Janeiro/PUC-RIO, mestranda responsável pela pesquisa abaixo referida, orientada pela professora $\mathrm{Dr}^{\mathrm{a}}{ }^{\mathrm{a}}$ Naira da Costa Muylaert Lima e pela professora Dr. ${ }^{a}$ Alícia Maria Catalano de Bonamino convidamos você para participar como voluntário(a) deste estudo. Ressaltamos que sua participação neste estudo é totalmente voluntária, livre de qualquer investimento financeiro, podendo desistir em qualquer momento durante a pesquisa. As informações contidas neste termo têm por objetivo firmar acordo escrito, autorizando sua participação com pleno conhecimento da natureza dos procedimentos a que você será submetido (a).

Pesquisa: Concepções de Alfabetização: O que dizem os professores da Rede Municipal de Ensino de Duque de Caxias/RJ.

\section{Pesquisadora Responsável:}

Mestranda: Tatiane Rodrigues Souza | tatiane.loretos@gmail.com | (021) 967085796

Orientadora: Prof. ${ }^{a}$ Dr. ${ }^{a}$ Naira da Costa Muylaert Lima | naira@puc-rio.br| (021) 35271815

Coorientadora: Prof. ${ }^{a}$ Dr. ${ }^{a}$ Alícia Maria Catalano de Bonamino| alicia@puc-rio.br| (021) 35271815

Justificativa: Este estudo se justifica por buscar analisar os motivos que levaram a SME/Duque de Caxias à reestruturação do currículo da rede de ensino e compreender as concepções de alfabetização dos professores da rede e dos documentos curriculares. Considero que as concepções de alfabetização na reformulação curricular no Município de Duque de Caxias são relevantes e algo do meu interesse, especialmente pelas dimensões teórico-práticas e cotidianas que envolvem minha própria experiência enquanto professora da rede municipal.

Objetivos: Este estudo tem como objetivo geral compreender as concepções de alfabetização dos professores alfabetizadores da rede municipal de educação de Duque de Caxias/RJ e dos documentos curriculares: aquele formulado em $2002 \mathrm{e}$ que ainda está em vigência; o que está em construção e a BNCC.

Metodologia: Numa primeira etapa será feita uma análise documental das concepções de alfabetização na Base Nacional Comum Curricular e também nos documentos normativos do currículo vigente no município de Duque de Caxias/RJ. Numa segunda etapa as informações serão coletadas através de entrevistas 
semiestruturadas (audiogravação) com professores alfabetizadores que estão envolvidos e participando das reuniões da reestruturação curricular. As entrevistas semiestruturadas serão gravadas via tecnologia digital de comunicação a distância. Todos os dados coletados serão arquivados e guardados pelo pesquisador responsável por essa pesquisa em local seguro no Departamento de Educação da PUC-Rio, por um período de 5 anos. Garanto ainda que as informações obtidas serão analisadas em conjunto com outros sujeitos, não sendo divulgada a identificação de nenhum dos participantes.

Riscos e benefícios: Há possibilidade de ocorrer algum constrangimento ao abordar temas relacionados às concepções de alfabetização. No entanto, todos os procedimentos levarão este risco em conta, respeitando os sujeitos envolvidos. Caso você se sinta constrangido ou desconfortável em responder alguma questão o/a entrevistado/a tem a liberdade de se retirar da entrevista imediatamente. Mesmo tendo um roteiro prévio não é possível delimitar o tempo que você gastará respondendo à pesquisa para minimizar este possível risco como cansaço, realizaremos pausa durante a entrevista. A pesquisadora, com vistas a minorar qualquer desconforto causado mediante as perguntas, explicará de forma mais detalhada o roteiro de entrevista, de forma a esclarecer possíveis dúvidas. Ao participar desta pesquisa você não terá nenhum benefício direto. Entretanto, esperamos que este estudo contribua com informações importantes sobre as concepções de alfabetização e sua implementação nas políticas curriculares, acrescentando elementos importantes à literatura, onde a pesquisadora se compromete a divulgar os resultados obtidos. Em caso de qualquer dúvida sobre a pesquisa, você poderá, a qualquer momento, entrar em contato com a professora Dr. ${ }^{a}$ Naira da Costa Muylaert Lima - seus contatos são: (21) 35271815 (PUCRIO), ou ainda pelo e-mail naira@puc-rio.br, ou com a Professora Dr. ${ }^{a}$ Alícia Maria Catalano de Bonamino ou ainda pelo e-mail alicia@puc-rio.br E, com a pesquisadora Tatiane Rodrigues Souza, pelos telefones (21) 967085796 ou pelo email tatiane.loretos@gmail.com ou no Programa de Pós-Graduação em Educação da PUC-Rio, localizado Rua Marquês de São Vicente, 225, Gávea - Rio de Janeiro, RJ - Brasil, Cep: 22451-900 - Cx. Postal: 38097 | Telefone: (55 21) 3527-1001 Caso você tenha dificuldade para entrar em contato com os pesquisadores responsáveis, comunique o fato ao Comitê de Ética em Pesquisa da PUC Rio, que funciona na Rua Marquês de São Vicente, 225_Gávea_CEP 22453-900 Rio de Janeiro RJ TEL(21) 3527-1618.Confidencialidade: As informações coletadas nesta pesquisa serão estritamente confidenciais, e serão divulgadas apenas em eventos ou publicações científicas, não havendo identificação dos voluntários, a não ser entre os responsáveis pelo estudo, sendo assegurado o sigilo sobre sua participação.

Financiamento da pesquisa: A pesquisa será financiada pela pesquisadora, o que inclui todos os gastos ao longo das etapas

$\mathrm{Eu}$, (nome do participante), de maneira voluntária, livre e esclarecida, concordo em participar da pesquisa acima identificada. Estou ciente dos objetivos do estudo, dos procedimentos metodológicos, dos possíveis desconfortos com o tema, das garantias de confidencialidade e da possibilidade de esclarecimentos permanentes sobre os mesmos. Fui informado(a) de que se trata de uma pesquisa em andamento no Programa de Pós-Graduação em Educação da PUC-Rio. Está claro que minha participação é isenta de despesas e que minha imagem e meu nome não serão 
publicados sem minha prévia autorização por escrito. Estou de acordo com a entrevista para fins acadêmicos. Estou ciente de que, em qualquer fase da pesquisa, terei a liberdade de recusar a minha participação ou retirar meu consentimento, sem nenhuma penalização ou prejuízo.

Autorizo o uso de vídeogravação
\begin{tabular}{|c|l|c|c|}
\hline Sim & Não & Autorizo o uso de áudiogravação \\
& & Sim & Não \\
\hline
\end{tabular}

Tatiane Rodrigues Souza, pesquisadora.

[assinatura do participante]

Nome completo:

Rio de Janeiro, de de 2020. 


\section{ROTEIRO PARA ENTREVISTA SEMIESTRUTURADA \\ PÚBLICO-ALVO: PROFESSORES \\ 1 - CARACTERÍSTICAS FORMAÇÃO / EXPERIÊNCIA}

Sexo:

Idade:

- Qual a sua formação acadêmica? (Área/Curso Superior/PósGraduação):

- Já pertenceu ou pertence a outra a rede educacional pública ou privada? Quais foram/são seus cargos/funções?

- Quanto tempo atua no Magistério? E nas classes de alfabetização?

- Já atuou nesta função como alfabetizador/a em outras escolas?

- Qual nome da sua escola?

- No total, quanto tempo você tem de experiência como professor da escola?

- Em quantas escolas da rede Municipal de Duque Caxias/RJ trabalhou? Quais foram ou são seus cargos/funções?

- Há quanto tempo você está na rede Municipal de Duque Caxias/RJ?

- Você participa do processo de reestruturação curricular da rede? Como? Quais são as suas atividades neste processo de reestruturação?

\section{EIXOS DE ANÁLISE}

(Eixo 1) Motivações que levaram a SME Duque Caxias/RJ á reestruturação do currículo da rede de ensino

- Em sua compreensão, o que levou a SME de Duque Caxias/RJ reestruturar o currículo?

- Na escola há profissionais que participam das equipes ou dos eventos (reuniões) de reestruturação curricular? Como eles foram selecionados para essa participação? Você participa ou já participou de alguma? Conte como foi/como é.

- Como era a participação desses profissionais no processo de reflexão e 
reestruturação curricular, em 2019, e durante a pandemia da COVID-19, em $2020 ?$

- Você sabe o que eles fazem nas atividades de reestruturação curricular? Eles compartilham com a equipe?

- Quais instrumentos/materiais a SME utiliza, mesmo que parciais, para divulgação dos resultados dessa reestruturação curricular para as escolas?

(Eixo 2) Concepções de alfabetização dos professores da rede muncipal de educação

- Para você o que é alfabetização? E o que é letramento?

- Qual concepção fundamenta o ensino de Caxias?

- Quais documentos normatizam e orientam o ensino da rede e da escola?

- Você sabe quais são as principais referências teóricas utilizadas nesses documentos?

- Quais cursos, congressos e eventos foram organizados nos últimos 2 (dois) anos pela SME de Duque Caxias/RJ com a temática 'alfabetização' que você tenha participado?

- Qual a sua opinião sobre o método fônico?

- Qual a sua opinião sobre o construtivismo?

- Quais concepções de alfabetização/letramento você considera relevantes e que contribuem para a garantia do aprendizado?

- Na sua opinião, quais as causas para a não alfabetização das crianças?

- Você sabe quais são os debates que estão ocorrendo no âmbito da reestruturação curricular? Quais são as concepções de alfabetização que estão sendo discutidas nos encontros?

(Eixo 3) Conhecimento dos professores sobre as concepções de alfabetização presentes nos documentos curriculares da rede de ensino e na BNCC

- Em sua opinião, quais são as concepções teóricas de alfabetização que 
fundamentaram o currículo anterior (2002)?

- Você já teve acesso ao documento Cadernos em Movimento? Sabe que documento é esse?

- Você utiliza/utilizou esse documento para pensar a sua prática docente? Como ele lhe foi útil?

- Você conhece a Base Nacional Comum Curricular/BNCC? Tem acesso a ela?

- O currículo em construção na rede leva em consideração as orientações da BNCC?

- Quais concepções teóricas de alfabetização fundamentaram o novo currículo em construção?

- Na sua opinião, quais sãos as aproximações e distanciamentos entre as concepções de alfabetização/letramento do currículos atual (2019/2020) e o anterior (2002), organizados/sugeridos pela SME de Duque Caxias/RJ? Ou seja, o que muda?

- Quais as aproximações e distanciamentos entre as concepções de alfabetização da reestruturação curricular e da Base Nacional Comum Curricular/BNCC? 


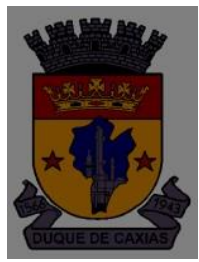

\author{
ESTADO DO RIO DE JANEIRO \\ PREFEITURA MUNICIPAL DE DUQUE DE CAXIAS \\ SECRETARIA MUNICIPAL DE EDUCAÇÃO \\ SUBSECRETARIA PEDAGÓGICA \\ CENTRO DE PESQUISA E FORMAÇÃO CONTINUADA PAULO FREIRE
}

Duque de Caxias, 11 de dezembro de 2020

Parecer $\mathbf{n}^{0}:$ 12/20 - CPFPF/SME-DC

Requerente: Tatiane Rodrigues Souza

Universidade ou agência associada: Pontifícia Universidade Católica do Rio de Janeiro (PUC-Rio)

Assunto: Autorização de pesquisa

\title{
DAS CONSIDERAÇÕES INICIAIS
}

De acordo com as atribuições deste Centro de Pesquisa e tendo sido observada a documentação anexa, as autorizações em nossa Rede são concedidas na condição de que sejam respeitadas as normas de decoro e adequabilidade estabelecidas pela Unidade Escolar.

\section{DA ANÁLISE}

Após a análise do projeto de pesquisa intitulado "Concepções de alfabetização: o que dizem os professores da Rede Municipal de Ensino de Duque de Caxias/RJ", cujo objetivo geral é "compreender as concepções de alfabetização dos professores alfabetizadores da Rede Municipal de Educação de Duque de Caxias/RJ e dos documentos curriculares: aquele formulado em 2002 e que ainda está em vigência, o que está em construção e a BNCC", constatou-se a necessidade da pesquisa de campo.

Ressalta-se que, para a realização de entrevistas, aplicação de questionários e/ou exercícios, uso de imagens ou quaisquer práticas outras relacionadas à pesquisa, deverão ser solicitadas autorizações de todos os envolvidos permitindo a utilização dos dados para fins acadêmicos e/ou científicos. No caso de menores, solicita-se a inclusão de uma autorização de seu responsável. 


\section{DA CONCLUSÃO}

Com base na avaliação criteriosa das informações apresentadas nos documentos, AUTORIZA-SE a realização da pesquisa. Vale ressaltar que as informações fornecidas ao pesquisador deverão ser arquivadas pelo tempo que determina a legislação e não poderão ser utilizadas em detrimento da Unidade Escolar, Secretaria Municipal de Educação, Prefeitura Municipal de Duque de Caxias e/ou indivíduos participantes, inclusive na forma de dano à estima, prestígio e/ou agravo econômico/financeiro. Outrossim, o anonimato de tais informações deverá ser garantido durante e após a pesquisa. Caso necessário, a qualquer momento poderemos revogar esta autorização se comprovadas atividades que causem prejuízo às instituições e/ou pessoas envolvidas.

Cordialmente,

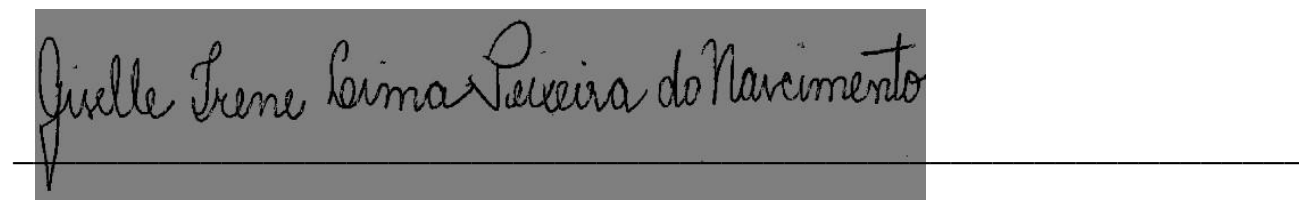

\section{GISELLE IRENE LIMA TEIXEIRA DO NASCIMENTO}

Diretora do CPFPF Matrícula: 06723-0

OBS.: Este termo é assinado em 2 vias, uma do/a voluntário/a e outra para os arquivos dos pesquisadores. 